\title{
CRIMES CONTRA A ARRECADAÇÃO PARA A SEGURIDADE SOCIAL: APROPRIAÇÃO INDÉBITA PREVIDENCIÁRIA E SONEGAÇÃO DE CONTRIBUIÇÃO PREVIDENCIÁRIA
}

Dissertação de Mestrado apresentada ao Departamento de Direito Penal, Medicina Forense e Criminologia da Faculdade de Direito da Universidade de São Paulo, como requisito parcial para obtenção do título de Mestre.

Orientador: Professor Doutor Eduardo Reale Ferrari

FACULDADE DE DIREITO DA UNIVERSIDADE DE SÃO PAULO

SÃO PAULO 


\section{A Anna Carolina}




\section{SUMÁRIO}

INTRODUÇÃO

\section{NASCIMENTO E DESENVOLVIMENTO DO SISTEMA DE SEGURIDADE} SOCIAL

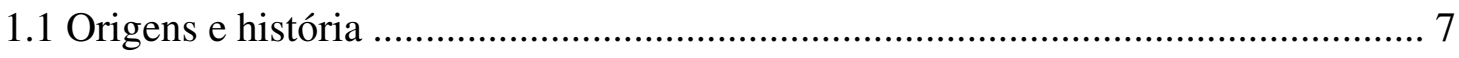

1.2 Lógica do individualismo e a necessidade de criação dos sistemas de custeio ..... 10

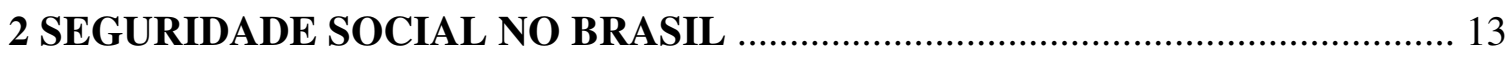

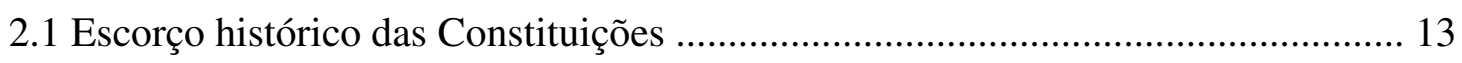

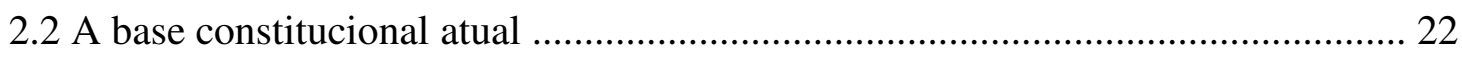

2.3 Natureza jurídica das contribuições previdenciárias ........................................... 26

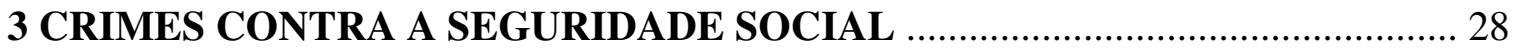

3.1 Necessária introdução: bem jurídico penal ....................................................... 28

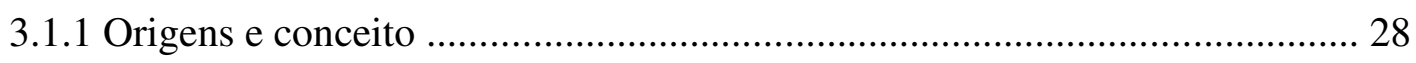

3.1.2 O que protegem os crimes contra a seguridade social? .............................. 33

3.1.2.1 Patrimônio público como bem jurídico ................................................. 39

3.1.2.2 O patrimônio dos contribuintes-trabalhadores como bem jurídico ........ 42

3.1.2.3 A livre concorrência das empresas como bem jurídico .......................... 44

3.1.2.4 A regular escrituração contábil como bem jurídico .............................. 47

3.1.2.5 Conclusão parcial: a arrecadação para a seguridade social

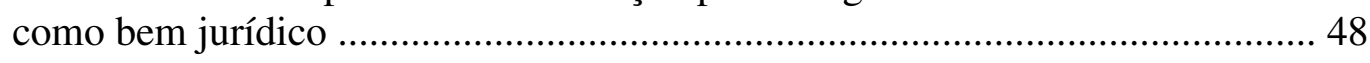

3.2 A prescrição normativa da Lei $\mathrm{n}^{\circ}$ 9.983/00: os tipos incriminadores .................... 51

3.2.1 Apropriação indébita previdenciária (Código Penal, artigo 168-A) .............. 51

3.2.1.1 Histórico legislativo ........................................................................ 51

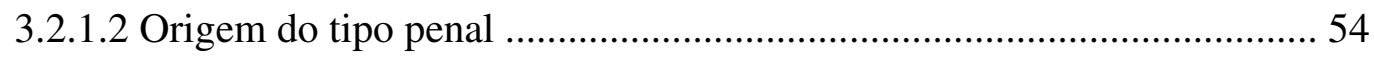

3.2.1.3 Conduta punível e análise dogmática ................................................. 55

3.3.2 Sonegação de contribuição previdenciária (Código Penal, artigo 337-A) ..... 62

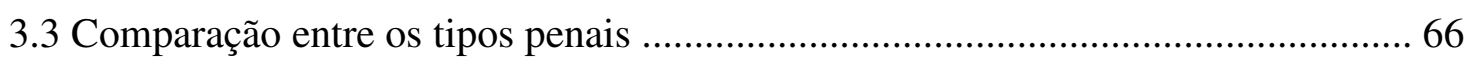




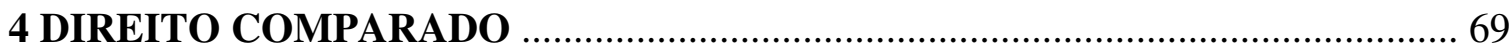

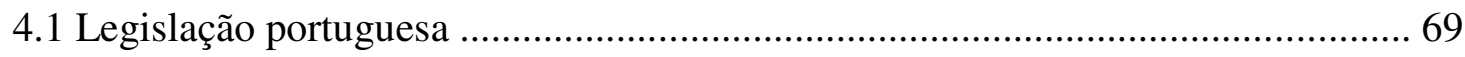

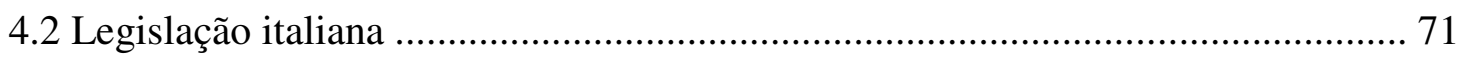

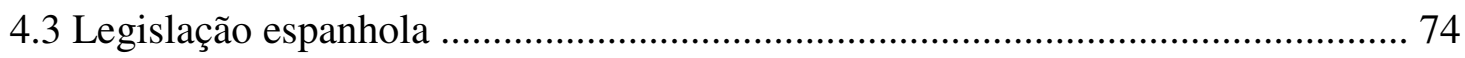

5 O CAMINHO OBTUSO DA DESCRIMINALIZAÇÃO: EXTINÇÃO DA PUNIBILIDADE PELO PAGAMENTO …................................ 76

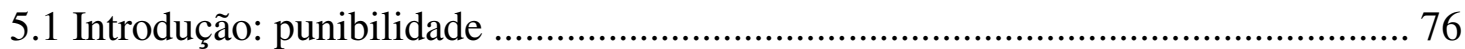

5.2 O Código Penal, as Leis $n^{\circ}$ 9.964/00 (REFIS I), nº 10.684/03 (REFIS II ou PAES) e a Medida Provisória n ${ }^{\circ}$ 303/06 (Refis III ou PAEX) ................................... 78

5.3 Direito Penal, Law and Economics e eficiência ................................................. 84

6 ADEQUAÇÃO E NECESSIDADE DA TUTELA PENAL ................................... 89

6.1 O Direito (Penal) como instrumento de controle social ...................................... 89

6.2 A terceira via proposta por Miguel Reale Júnior .................................................. 97

$6.3 \mathrm{O}$ delito previdenciário e o Direito Penal Econômico ............................................ 100

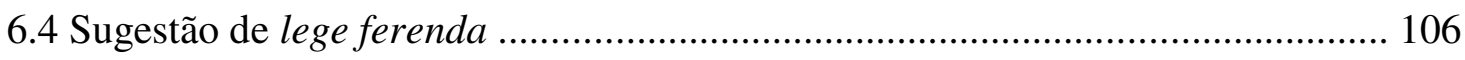

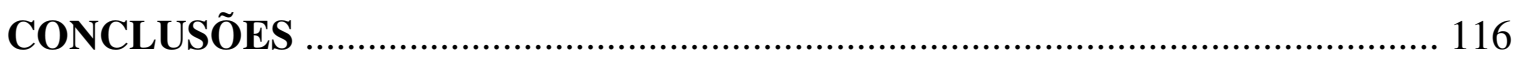

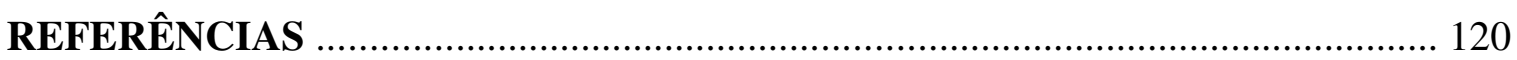

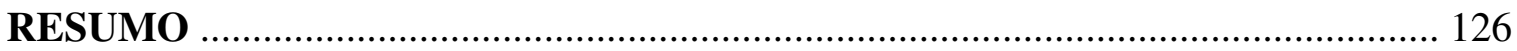

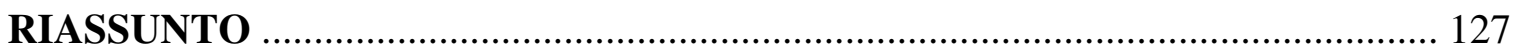

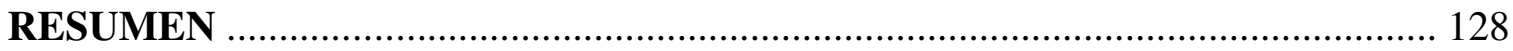

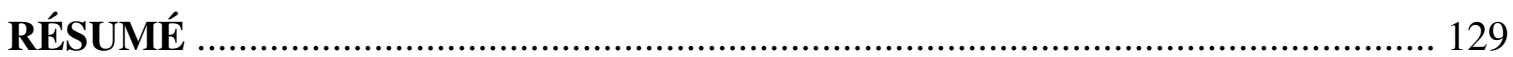




\section{INTRODUÇÃO}

O presente trabalho se propõe a analisar dois tipos criminalizadores inseridos em nosso Código Penal pela Lei $n^{\circ}$ 9.983/00, quais sejam, a apropriação indébita previdenciária (artigo 168-A) e a sonegação de contribuição previdenciária (artigo 337-A).

Pretende-se uma análise dogmática, a partir do texto legal.

Por ser recente a tipificação, a ciência jurídica ainda não se dedicou aos temas com a profundidade necessária, sendo escassa a produção monográfica a respeito. Alguns dos autores que se dedicaram à análise cuidam com propriedade das questões relativas à matéria previdenciária, descuidando-se, por vezes, de uma abordagem crítica, voltada primordialmente às questões penais.

Neste diapasão, a dissertação elaborada tem intenção de discutir a estrutura dos tipos, abordando aspectos clássicos da Teoria do Delito, relativos à conduta e suas classificações, aos sujeitos e ao elemento subjetivo. Para isso, necessário delimitar alguns conceitos próprios do Direito Previdenciário, bem como realizar breve estudo acerca da menção que a matéria recebeu dos textos constitucionais anteriores e do atual. Quando se entendeu proveitoso ao trabalho, foram realizadas anotações históricas acerca do momento político em que as normas vieram ao ordenamento jurídico.

No que concerne à criminalização das condutas atentatórias à arrecadação das contribuições sociais, fez-se útil elaborar histórico das legislações que procuraram, por meio do Direito Penal, fortalecer o sistema de contribuição, desde a Lei no 65, de 14 de dezembro de 1937, editada sob o governo Vargas.

Capítulo à parte mereceu o estudo da extinção da punibilidade pelo pagamento nos delitos previdenciários. Trata-se de instituto legislativo inspirado no princípio da eficiência, conhecido de longa data da Ciência Econômica e do Direito Administrativo, hoje positivado em nosso texto constitucional. Como se verá, em que pesem eventuais virtudes do instituto, cuidou-se de apontar as incoerências que ele trouxe ao sistema punitivo penal.

A fim de agregar ao trabalho o tratamento dado à questão por outros países, foi levado a efeito estudo de direito comparado, em que se transcreveu e analisou, à luz do 
Direito Penal brasileiro, os dispositivos que, lá, cuidam de matéria semelhante. Escolheuse para a análise a legislação portuguesa, italiana e espanhola. A opção por tais países ultimou-se devido à facilidade de acesso às respectivas línguas - o que torna a investigação mais precisa -, à similitude do sistema jurídico desses países com o Brasil e à influência que, inegavelmente, tais nações ainda exercem sobre nossa cultura jurídica.

Como sugestão legislativa, propõe-se a descriminalização das condutas ofensivas à seguridade social, com a criação de um Tribunal Administrativo Penal, nos moldes sugeridos por Miguel Reale Júnior, sem descurar de eventual contribuição da doutrina administrativista, representada por Floriano de Azevedo Marques Neto. 


\title{
1 NASCIMENTO E DESENVOLVIMENTO DO SISTEMA DE SEGURIDADE SOCIAL
}

\author{
1.1 Origens e história
}

O Direito Romano contemplou institutos que são considerados originários da contemporânea seguridade social. Alguns citam a própria forma de organização da sociedade romana, ao redor do paterfamilias, como uma modalidade de associação para a ajuda aos mais necessitados: era ele quem estabelecia o domicílio da família e a ele cabia, também, a obrigação de prover o sustento dos seus ${ }^{1}$. Aponta-se, outrossim, os chamados colégios - collegia - gregos e romanos: o destaque conferido a essas instituições decorre de sua natureza mutualista, na medida em que buscavam, além de finalidades religiosas e econômicas, manter um regime de ajuda recíproca entre seus membros ${ }^{2}$. Merecem destaque, ainda, certos benefícios auferidos pelos soldados veteranos, como terras e valores monetários $^{3}$.

Note-se, contudo, que muito embora possa se falar existente o mutualismo, que é a pedra angular do contemporâneo sistema de seguridade social, os institutos nele inspirados eram de caráter puramente privado, ou seja: a Antiguidade não conheceu a seguridade social de caráter público, até porque o Estado, como hoje estruturado, ainda não havia se instituído, o que vem acontecer, somente, com o advento da Idade Moderna.

A Idade Média aproximou, sobremaneira, o público do privado. Exercendo o poder de forma descentralizada, cada um dos senhores feudais era órgão de jurisdição e, cada feudo, uma unidade de produção. Em seus domínios o senhor feudal ditava as normas e impunha sua vontade. As collegia da Antiguidade deram lugar às guildas ${ }^{4}$, que eventualmente incluíam entre suas atividades a prestação de assistência em caso de doença

\footnotetext{
${ }^{1}$ MARKY, Thomas. Curso Elementar de Direito Romano. 8. ed. São Paulo: Saraiva, 1995. p. 163.

2 ROCHA, Daniel Machado da. O direito fundamental à previdência social. Porto Alegre: Livraria do Advogado, 2004. p. 21.

${ }^{3}$ CAMARGO DOS SANTOS, Leandro Luis. Curso de Direito da Seguridade Social. São Paulo: LTr, 2005. p. 31 .

4 s.f. durante a Idade Média, associação coorporativa de artistas, artesãos, mercadores, etc. (CALDAS AULETE. Dicionário contemporâneo da Língua Portuguesa. 3. v. 5. ed. Rio de Janeiro: Delta, 1964. p. 2008.
} 
e a cobertura de despesas de funeral ${ }^{5}$. Também há menção, nesse período, às corporações, representadas pelos grêmios e confrarias, que desenvolveram, entre seus membros, o mutualismo.

Nessa mesma época histórica tem-se conhecimento dos primeiros contratos de seguro: a notícia da preocupação do homem com relação ao infortúnio é de 1344. Ocorre neste ano a celebração do primeiro contrato de seguro marítimo, posteriormente surgindo a cobertura de riscos contra incêndio ${ }^{6}$.

$\mathrm{Na}$ Idade Moderna figuram como responsáveis pelo atendimento das necessidades sociais as irmandades de socorro e os montepios. Estes últimos passam a receber subvenção do Estado, apesar de estarem restritos a indivíduos que desempenhassem atividades profissionais específicas, tais como a dos militares e do funcionalismo público. Henrique VIII, na Inglaterra, em 1536, determinou às autoridades municipais que proporcionassem auxílio aos pobres ${ }^{7}$.

Em 1601, na Inglaterra, foi editada a Lei de Amparo aos Pobres (Poor Law ou Poor Relief Act), que instituiu contribuição obrigatória para fins sociais, além de rever e consolidar outros atos relativos à assistência pública.

Seguindo a linha evolutiva, a lei prussiana de 1810 previu o seguro-doença para os assalariados e na Áustria, em 1854, foram criados institutos para amparar a invalidez e a velhice. Bismarck, em 1883, instituiu o seguro-doença universal, estendido à generalidade da força laboral alemã. Em 1911, as leis de acidentes de trabalho, seguros de velhice e invalidez foram consolidadas no instrumento que se convencionou chamar de Código de Seguros Sociais.

\footnotetext{
5 ROCHA, Daniel Machado da. O direito fundamental à previdência social. Porto Alegre: Livraria do Advogado, 2004. p. 23.

${ }^{6}$ MARTINS, Sergio Pinto. Direito da Seguridade Social. 9. ed. São Paulo: Atlas, 1998. p. 29.

${ }^{7}$ ROCHA, Daniel Machado da. O direito fundamental à previdência social. Porto Alegre: Livraria do Advogado, 2004. p. 26.
} 
No mesmo ano, na Inglaterra, o desemprego involuntário passou a ser tutelado pelos seguros sociais ${ }^{8}$, ampliando os benefícios do Workmen's Compensation Act, de 1897, que estabeleceu a obrigatoriedade do seguro contra acidentes de trabalho.

Em 1941, ainda na Inglaterra, o Plano Beveridge traçou as linhas de um programa de prosperidade política e social, garantindo ingressos suficientes para que o indivíduo ficasse acobertado por certas contingências sociais, como a indigência, ou quando, por qualquer motivo, não pudesse trabalhar ${ }^{9}$.

Merece menção, outrossim, a Carta Encíclica Rerum Novarum, do Papa Leão XIII, sobre a condição dos operários ${ }^{10}$, bem como a Quadragesima Anno ${ }^{11}$, de Pio XI. À época de suas edições, respectivamente 1891 e 1931, é inegável que a Igreja Católica Cristã exercia influência sobre a sociedade ocidental e determinava, com bastante destaque, os seus rumos.

Para além do velho continente, há de se fazer alusão à constituição mexicana de 1917, que tratou do seguro social, e ao Social Security Act, de 14 de agosto de 1935, nos Estados Unidos da América ${ }^{12}$. Este foi parte integrante do New Deal, de Roosevelt, plano

\footnotetext{
${ }^{8}$ ROCHA, Daniel Machado da. O direito fundamental à previdência social. Porto Alegre: Livraria do Advogado, 2004. p. 36.

${ }^{9}$ MARTINS, Sergio Pinto. Direito da Seguridade Social. 9. ed. São Paulo: Atlas, 1998. p. 30.

${ }^{10}$ Segue breve transcrição: (...) mas, ainda que todos os cidadãos, sem excepção, devam contribuir para a massa dos bens comuns, os quais, aliás, por um giro natural, se repartem de novo entre os indivíduos, todavia as constituições respectivas não podem ser nem as mesmas, nem de igual medida. Quaisquer que sejam as vicissitudes pelas quais as formas do governo são chamadas a passar, haverá sempre entre os cidadãos essas desigualdades de condições, sem as quais uma sociedade não pode existir nem conceber-se. Sem dúvida são necessários homens que governem, que façam leis, que administrem justiça, que, enfim, por seus conselhos ou por via da autoridade, administrem os negócios da paz e as coisas da guerra. (...) Mais ainda: nesta ordem de coisas, o trabalho tem uma tal fecundidade e tal eficácia, que se pode afirmar, sem receio de engano, que ele é a fonte única de onde procede a riqueza das nações. A equidade manda, pois, que o Estado se preocupe com os trabalhadores, e proceda de modo que, de todos os bens que eles proporcionam à sociedade, lhes seja dada uma parte razoável, como habitação e vestuário, e que possam viver à custa de menos trabalho e privações. De onde resulta que o Estado deve favorecer tudo o que, de perto ou de longe, pareça de natureza a melhorar-lhes a sorte. Esta solicitude, longe de prejudicar alguém, tornar-se-á, ao contrário, em proveito de todos, porque importa soberanamente à nação que homens, que são para ela o princípio de bens tão indispensáveis, não se encontrem continuamente a braços com os horrores da miséria. Disponível em <http://www.vatican.va/holy_father/leo_xiii/encyclicals/documents/hf_lxiii_enc_15051891_rerum-novarum_po.html>, acesso em 3.jan.2008.

11 Disponível em <http://www.vatican.va/holy_father/pius_xi/encyclicals/documents/hf_pxi_enc_19310515_quadragesimo-anno_po.html>, acesso em 3.jan.2008.

${ }^{12}$ CAMARGO DOS SANTOS, Leandro Luis. Curso de Direito da Seguridade Social. São Paulo: LTr, 2005. p. 32.
} 
de recuperação econômica e social implementado para combater a grave crise econômica de 1929.

1.2 Lógica do individualismo e a necessidade de criação dos sistemas de custeio

$\mathrm{Na}$ sociedade moderna se vive a lógica do individualismo, que prepondera sobre qualquer interesse coletivo. E a história recente pode explicar tal fenômeno: uma vez que o Estado tem sob sua guarda todos os indivíduos, cada um deles deixa de se sentir responsável pelos demais. Já que se construiu um Estado onipotente, cada um dos indivíduos se sente desobrigado de qualquer prestação para com os outros. Acima de todos há uma figura que desonera os demais entes sociais: o Estado.

Estabelece-se uma lógica ingrata e contraproducente para a vida social, baseada no gigantismo das funções estatais e na relativização dos papéis individuais.

Ainda hoje há quem diga que tem o direito de sujar os logradouros públicos, pois paga impostos que financiam a limpeza pública. Há quem deliberadamente cometa infrações de trânsito, suportando, deliberadamente e caso venha a ocorrer, a aplicação da respectiva sanção. A extrema individualização degenera as relações subjetivas. O indivíduo que transgride determinada norma de conduta social, seja cometendo um ilícito civil ou, até mesmo, um crime, não tem a percepção de que está agindo contra outro membro social que goza das mesmas prerrogativas.

Quem opta pelo comportamento desvirtuado sabe que assume postura indesejável, mas enxerga como vítima o Estado, e não o outro indivíduo. Tal fenômeno ocorre porque, antes da ofensa a direito de outra pessoa, percebe-se a ofensa ao ordenamento jurídico. Assim, quem furta tem como primeira idéia cognitiva a transgressão da norma (comportamento contrário ao Estado), e não eventuais dissabores que causará ao proprietário do patrimônio. Assim, a escolha individual pelo comportamento desviado surge como afronta ao Estado, e não como afronta a um igual.

A necessidade de instituição de programas de seguridade social, o que na prática significa a estatização da solidariedade, tem origem na incapacidade das comunidades em dar suporte às vicissitudes que cada um dos indivíduos enfrenta ao longo da vida (doenças, maternidade, desemprego, velhice, por exemplo). Nascem, assim, os 
chamados sistemas de custeio, que procuram equacionar a arrecadação, poupança e repartição da riqueza, entre os quais se destaca o Bismarckiano e o Beverdgeano.

A doutrina previdenciária aponta dois mecanismos de proteção, dois métodos diversos de recolhimento, administração e repartição dos valores. As concepções de custeio da seguridade atuam, basicamente, entre gerações (dos jovens, força de trabalho ativa, para os mais velhos) e intragerações (dos mais ricos aos mais pobres).

No Brasil atua um aparelho composto: assim, pode-se afirmar que o sistema previdenciário nacional opera sobre bases mistas, com elementos Bismarckianos $e$ Beverdgeanos $^{13}$. Para Gilciane Allen Baretta, o sistema previdenciário brasileiro é baseado no princípio da solidariedade entre as gerações, ou seja, a população economicamente ativa sustenta a população inativa ${ }^{14}$.

A concepção Bismarckiana nasceu da iniciativa de Otto Von Bismarck ${ }^{15}$ e determinava um seguro-doença aos operários da indústria alemã, que era custeado pelo Estado, pelos trabalhadores e pelas empresas. A esta primeira experiência, de 1883, seguiuse a instituição de seguros por acidente de trabalho (1884), invalidez e velhice (1889).

Lord William Beveridge ${ }^{16}$, um liberal inglês, instituiu como marco inicial (1911) o seguro-desemprego ${ }^{17}$. Posteriormente, em 1942, o Relatório Beveridge ${ }^{18}$ trouxe as bases do sistema do Welfare State, adotado após a Segunda Grande Guerra Mundial por muitos países da Europa ocidental.

Em relação ao sistema idealizado por Bismarck, o de William Beveridge implica um maior grau de distribuição de renda dentro de uma mesma geração ${ }^{19}$.

\footnotetext{
13 JORGE, Társis Nametala Sarlo. Teoria Geral do Direito Previdenciário. Rio de Janeiro: Lúmen Júris, 2005. p. 27.

14 BARETTA, Gilciane Allen. Os crimes fiscais e previdenciários. A extinção da punibilidade. Belo Horizonte: Mandamentos, 2004. p. 97.

${ }^{15}$ Biografia disponível em <http://en.wikipedia.org/wiki/Otto_Von_Bismarck>, acesso em 20.abr.2006.

${ }^{16}$ Biografia disponível em <http://en.wikipedia.org/wiki/William_Beveridge>, acesso em 20.abr.2006.

${ }^{17}$ BARROS, Roque Spencer Maciel de. A face humana do liberalismo. Jornal da USP. Entrev. a Roberto C. G. Castro. Disponível em <http://www.usp.br/ jorusp/arquivo/1997/jusp400/manchet/rep_res/rep_int/ univers2.html>, acesso em 20.abr.2006.

${ }^{18}$ Título original: Social Insurance and Allied Services.

19 JORGE, Társis Nametala Sarlo. Teoria Geral do Direito Previdenciário. Rio de Janeiro: Lumen Juris, 2005. p. 27.
} 
Estrutura-se, assim, um sistema social de proteção aos menos validos, que demanda, obviamente, financiamento público. Nasce a necessidade de custeio dos programas de assistência social e, com ela, a obrigação de contribuição financeira a esse custeio. 


\section{SEGURIDADE SOCIAL NO BRASIL}

\subsection{Escorço histórico das Constituições}

A primeira constituição do Brasil, de $1824^{20}$, germinou embebida na ideologia liberal do século XVIII ${ }^{21}$. Nesse contexto o Estado tinha papel minimalista, voltado, apenas, à manutenção dos direitos naturais e da separação dos poderes ${ }^{22}$. Cumpria ao Estado, assim, legislar, gerir seu patrimônio, entregar os serviços públicos básicos e prover a defesa interna e externa da nação.

Citando Antonio Carlos Wolkmer, Daniel Machado da Rocha aponta que a Carta de 1824, axiologicamente, refletia o interesse dos grandes latifundiários escravocratas $(\ldots)^{23}$.

Merecem destaque, no que concerne à seguridade social, dois incisos do artigo $179^{24}$ :

Art. 179. A inviolabilidade dos Direitos Civis, e Politicos dos Cidadãos Brazileiros, que tem por base a liberdade, a segurança individual, e a propriedade, é garantida pela Constituição do Imperio, pela maneira seguinte.

(...)

XXIV. Nenhum genero de trabalho, de cultura, industria, ou commercio póde ser prohibido, uma vez que não se opponha aos costumes publicos, á segurança, e saude dos Cidadãos.

XXXI. A Constituição tambem garante os soccorros publicos.

20 Disponível em <http://www.planalto.gov.br/ccivil_03/Constituicao/Constituiçao24.htm>, acesso em 10.out.2007.

${ }^{21}$ ROCHA, Daniel Machado da. O direito fundamental à previdência social. Porto Alegre: Livraria do Advogado, 2004. p. 48.

${ }^{22}$ A Constituição Política do Império do Brazil, de 1824, observava a formulação quadripartita de Benjamim Constant: Poder Legislativo, Poder Moderador, Poder Executivo e Poder Judiciário. O Poder Legislativo era exercido pela assembléia geral, composta de duas câmaras (...) O Poder Moderador, considerado a chave de toda a organização política, era exercido privativamente pelo Imperador, como chefe supremo da nação (...) O Poder Executivo, exercido pelos ministros de Estado, tinha como chefe também o imperador. O Poder Judiciário, independente, era composto de juízes e jurados (SILVA, José Afonso da. Curso de Direito Constitucional Positivo. 10. ed. São Paulo: Malheiros, 1995. p. 76.)

23 ROCHA, Daniel Machado da. O direito fundamental à previdência social. Porto Alegre: Livraria do Advogado, 2004. p. 49.

${ }^{24}$ Respeitada a grafia original. 
O texto é muito mais tímido do que o elaborado pela Assembléia Geral Constituinte e Legislativa que, dissolvida à força armada em 12 de novembro de 1823, não viu sua proposta ser implementada ${ }^{25}$.

Sob a égide da Constituição de 1824 sublinha-se, ainda, a vigência do Código Comercial de 1850, que em seu artigo 79, garantia aos feitores, guarda-livros e caixeiros a manutenção de seus vencimentos, por até três meses, na ocorrência de acidentes imprevistos e inculpados.

O Império sucumbe aos federalistas. Essa força descentralizadora, que organizou rebeliões ${ }^{26}$ durante todo o período monárquico, proclama a República em 15 de novembro de 1889 e, como seu corolário, vem a lume nova constituição.

Com a Constituição da República dos Estados Unidos do Brasil, de 24 de fevereiro de $1891^{27}$, é utilizada, pela primeira vez, a palavra aposentadoria, instituída em benefício dos funcionários públicos ${ }^{28}$. Eis o texto constitucional: Art 75 - A aposentadoria só poderá ser dada aos funcionários públicos em caso de invalidez no serviço da Nação.

No que diz respeito à organização do Estado em Federação foi importado o modelo norte-americano, o que consolidou um republicanismo fortemente autoritário ${ }^{29}$. Economicamente o Brasil inseria-se no capitalismo internacional, fornecendo matériaprima e consumindo, mediante importação, produtos manufaturados. O contexto político é de disputa entre os coronéis rivais ${ }^{30}$, verdadeiros senhores feudais tupiniquins ${ }^{31}$.

\footnotetext{
${ }^{25}$ O projeto estabelecia que a Assembléia terá particular cuidado em conservar o augmentar as casas de misericórdia, hospitaes, rodas de expostos e outros estabelecimentos de caridade já existentes, e em fundar novos (...) Erigir-se-ão casos de trabalho para os que não acham empregos, e casas de correção e trabalho, penitencia e melhoramento para os vadios e dissolutos de um e outro sexo e para os criminosos condemnados (ROCHA, Daniel Machado da. O direito fundamental à previdência social. Porto Alegre: Livraria do Advogado, 2004. p. 49).

${ }^{26}$ As Balaiadas, Cabanadas, Sabinadas.

27 Disponível em <http://www.planalto.gov.br/ccivil_03/Constituicao/Constituiçao91.htm>, acesso em 10.out.2007.

${ }^{28}$ CAMARGO DOS SANTOS, Leandro Luis. Curso de Direito da Seguridade Social. São Paulo: LTr, 2005. p. 32.

29 Tércio Sampaio Ferraz Júnior, citado em ROCHA, Daniel Machado da. $O$ direito fundamental à previdência social. Porto Alegre: Livraria do Advogado, 2004. p. 51.

${ }^{30}$ Com esteio em Pedro Calmon, aponta José Afonso da Silva: o fenômeno do coronelismo tem suas leis próprias e funciona na base da coerção da força e da lei oral, bem como de favores e obrigações. Esta interdependência é fundamental: o coronel é aquele que protege, socorre, homizia e sustenta materialmente seus agregados; por sua vez, exige deles a vida, a obediência e a fidelidade. É por isso que o coronelismo
} 
É no período de vigência da Constituição de 1891 que foi editado o Decreto ${ }^{\circ}$ 4.682, de 24 de janeiro de 1923, conhecido como Lei Eloy Chaves ${ }^{32}$, que nos termos de sua ementa crea, em cada uma das emprezas de estradas de ferro existentes no paiz, uma caixa de aposentadoria e pensões para os respectivos empregados ${ }^{33}$. Posteriormente, os benefícios da Lei Eloy Chaves ${ }^{34}$ foram estendidos aos trabalhadores portuários e marítimos (1926) e ao pessoal das empresas de serviços telegráficos e rádio-telegráficos (1928).

Em 1926, por Emenda Constitucional de 3 de setembro, o Congresso Nacional foi autorizado a legislar sobre licença, aposentadoria e reformas. Em 1934 foi criado o Instituto de Aposentadoria e Pensão dos Comerciários e, também, o Instituto de Aposentadoria e Pensões dos Bancários ${ }^{35}$.

Em 1930 sobe ao poder Getúlio Vargas, que intervém nos Estados, liquida com a política dos governadores e afasta a influência dos coronéis ${ }^{36}$. Promove-se uma profunda mudança na estrutura do país, no que diz respeito à seara econômica. Vargas se impôs sobre as forças semifeudais que até então dominavam o Brasil, entretanto, o movimento vitorioso adotou tímidas medidas para a resolução dos problemas sociais que afligiam o País, mantendo-se, no essencial, a estrutura de dominação ${ }^{37}$.

Foi criado o Ministério do Trabalho, em 1930, sob a égide do qual se procedeu a intensa sindicalização das classes patronais e operárias.

significa força política e força militar (SILVA, José Afonso da. Curso de Direito Constitucional Positivo. 10. ed. São Paulo: Malheiros, 1995. p. 81).

${ }^{31}$ ROCHA, Daniel Machado da. O direito fundamental à previdência social. Porto Alegre: Livraria do Advogado, 2004. p. 50.

32 Disponível em <http://www.planalto.gov.br/ccivil_03/decreto/1910-1929/D4682.htm>, acesso em 11.out.2007.

${ }^{33}$ Mantida a grafia original.

${ }^{34}$ Referida norma é considerada grande marco do direito previdenciário brasileiro (CORREIA, Marcos Orione Gonçalves; CORREIA, Érika Paula Barcha. Curso de Direito da Seguridade Social. 2. ed. São Paulo: Saraiva, 2002. p. 13).

${ }^{35}$ MARTINS, Sergio Pinto. Direito da Seguridade Social. 9. ed. São Paulo: Atlas, 1998. p. 32.

${ }^{36}$ SILVA, José Afonso da. Curso de Direito Constitucional Positivo. 10. ed. São Paulo: Malheiros, 1995. p. 82.

${ }^{37}$ Luis Roberto Barroso, citado por ROCHA, Daniel Machado da. $O$ direito fundamental à previdência social. Porto Alegre: Livraria do Advogado, 2004. p. 54. 
Aos 16 de julho de 1934 foi promulgada a segunda Constituição da República dos Estados Unidos do Brasil ${ }^{38}$. Pela primeira vez o texto constitucional fez referência à expressão previdência, embora não a adjetivasse de social $^{39}$. A Constituição de 1934 , ao lado da clássica declaração de direitos e garantias individuais, inscreveu um título sobre a ordem econômica e social e outro sobre a família, a educação e a cultura. Referidas normas, de caráter programático, foram inspiradas na Constituição alemã de Weimar ${ }^{40}$. Houve significativa inserção dos direitos sociais em nosso ordenamento.

Verifique-se o texto constitucional, no que importa ao presente estudo:

Art. 121 - A lei promoverá o amparo da produção e estabelecerá as condições do trabalho, na cidade e nos campos, tendo em vista a proteção social do trabalhador e os interesses econômicos do País.

$\S 1^{\circ}$ - A legislação do trabalho observará os seguintes preceitos, além de outros que colimem melhorar as condições do trabalhador:

(...)

h) assistência médica e sanitária ao trabalhador e à gestante, assegurando a esta descanso antes e depois do parto, sem prejuízo do salário e do emprego, e instituição de previdência, mediante contribuição igual da União, do empregador e do empregado, a favor da velhice, da invalidez, da maternidade e nos casos de acidentes de trabalho ou de morte;

(...)

$\S 8^{\circ}$ - Nos acidentes do trabalho em obras públicas da União, dos Estados e dos Municípios, a indenização será feita pela folha de pagamento, dentro de quinze dias depois da sentença, da qual não se admitirá recurso ex-officio.

Com relação aos funcionários públicos, foi garantido o direito à aposentadoria integral, entre outros:

Art 170. O Poder Legislativo votará o Estatuto dos Funcionários Públicos, obedecendo às seguintes normas, desde já em vigor:

(...)

$4^{\circ}$ ) a invalidez para o exercício do cargo ou posto determinará a aposentadoria ou reforma, que, nesse caso, se contar o funcionário mais de trinta anos de serviço público efetivo, nos termos da lei, será concedida com os vencimentos integrais;

$5^{\circ}$ ) o prazo para a concessão da aposentadoria com vencimentos integrais, por invalidez, poderá ser excepcionalmente reduzido nos casos que a lei determinar;

$\left.6^{\circ}\right)$ o funcionário que se invalidar em conseqüência de acidente ocorrido no serviço será aposentado com vencimentos integrais, qualquer que seja o seu

38 Disponível em <http://www.planalto.gov.br/ccivil_03/Constituicao/Constituiçao34.htm>, acesso em 11.out.2007.

${ }^{39}$ MARTINS, Sergio Pinto. Direito da Seguridade Social. 9. ed. São Paulo: Atlas, 1998. p. 34.

${ }^{40}$ SILVA, José Afonso da. Curso de Direito Constitucional Positivo. 10. ed. São Paulo: Malheiros, 1995. p. 83. 
tempo de serviço; serão também aposentados os atacados de doença contagiosa ou incurável, que os inabilite para o exercício do cargo;

(...)

10) os funcionários terão direito a férias anuais, sem descontos; e a funcionária gestante, três meses de licença com vencimentos integrais.

É também na Constituição de 1934 que se prevê a tríplice forma de custeio, para o qual deveriam colaborar a União, o empregador e o empregado ${ }^{41}$.

Em 1937 Getúlio Vargas dissolve a Câmara e o Senado, revoga a Constituição de 1934 e decreta, aos 10 dias do mês de novembro, nova Constituição dos Estados Unidos do Brasil $^{42}$. Nas palavras de José Afonso da Silva ${ }^{43}$,

a Carta de 1937 não teve, porém, aplicação regular. Muitos de seus dispositivos permaneceram letra morta. Houve ditadura pura e simples, com todo o Poder Executivo e Legislativo concentrado nas mãos do Presidente da República, que legislava por via de decretos-lei que ele próprio depois aplicava. Vinte e uma emendas sofreu essa Constituição, através de leis constitucionais, que a alteravam ao sabor das necessidades e conveniências do momento e, não raro, até do capricho do chefe de governo.

Para Walter Costa Porto, citado por Daniel Machado da Rocha ${ }^{44}$, $a$ Constituição outorgada pelo golpe de Estado de 1937 é então justificada como um imperativo de salvação nacional. Para confirmar o quanto alegado, basta consultar seu preâmbulo $^{45}$.

${ }^{41}$ O artigo 195 da Constituição da República de 1988 indica como responsáveis por carrear recursos ao sistema a União, o Distrito Federal, os Estados, os Municípios, o empregador, a empresa ou entidade a ela equiparada, o trabalhador, o importador de bens ou serviços do exterior, bem como parcela da receita sobre os concursos de prognósticos.

42 Disponível em <http://www.planalto.gov.br/ccivil_03/Constituicao/Constituiçao37.htm>, acesso em 11.out.2007.

${ }^{43}$ SILVA, José Afonso da. Curso de Direito Constitucional Positivo. 10. ed. São Paulo: Malheiros, 1995. p. 84.

${ }^{44}$ ROCHA, Daniel Machado da. O direito fundamental à previdência social. Porto Alegre: Livraria do Advogado, 2004. p. 60.

${ }^{45}$ O Presidente da República dos Estados Unidos do Brasil, atendendo às legitimas aspirações do povo brasileiro à paz política e social, profundamente perturbada por conhecidos fatores de desordem, resultantes da crescente agravação dos dissídios partidários, que, uma, notória propaganda demagógica procura desnaturar em luta de classes, e da extremação, de conflitos ideológicos, tendentes, pelo seu desenvolvimento natural, resolver-se em termos de violência, colocando a Nação sob a funesta iminência da guerra civil; atendendo ao estado de apreensão criado no País pela infiltração comunista, que se torna dia a dia mais extensa e mais profunda, exigindo remédios, de caráter radical e permanente; atendendo a que, sob as instituições anteriores, não dispunha o Estado de meios normais de preservação e de defesa da paz, da segurança e do bem-estar do povo; sem o apoio das forças armadas e cedendo às inspirações da opinião nacional, umas e outras justificadamente apreensivas diante dos perigos que ameaçam a nossa unidade e da rapidez com que se vem processando a decomposição das nossas instituições civis e políticas; resolve assegurar à Nação a sua unidade, o respeito à sua honra e à sua independência, e ao povo brasileiro, sob um 
No que concerne à seguridade social vale mencionar que o texto não evoluiu, mas ao contrário. Foram suprimidas inúmeras disposições legais se tomado como padrão de comparação do texto de 1934. Destacam-se, na Carta de 1937, somente, duas prescrições, que vêm no artigo 137:

Art 137 - A legislação do trabalho observará, além de outros, os seguintes preceitos:

(...)

m) a instituição de seguros de velhice, de invalidez, de vida e para os casos de acidentes do trabalho;

n) as associações de trabalhadores têm o dever de prestar aos seus associados auxílio ou assistência, no referente às práticas administrativas ou judiciais relativas aos seguros de acidentes do trabalho e aos seguros sociais.

Relativamente à nomenclatura, diferentemente da Constituição de 1934 que adotou a terminologia previdência, a Carta de 1937 utilizou-se da expressão seguro social.

Cerca de um mês após instaurada a nova ordem constitucional, nasce o primeiro texto normativo que define como crime a conduta de apropriação indébita previdenciária $^{46}$ :

Art. 5'. O empregador que retiver as contribuições recolhidas de seus empregados e não as recolher na época própria incorrerá nas penas do art. $331, \mathrm{n}^{\circ}$ 2, da Consolidação das Leis Penais, sem prejuízo das demais sanções estabelecidas neste decreto-lei.

Cite-se que durante a vigência da Carta de 1937, pelo Decreto n ${ }^{\circ} 7.526$, de 7 de maio de 1945, foi prevista a criação do Instituto de Serviços Sociais do Brasil (ISSB), órgão que teria a função de concentrar e administrar todos os empregados ativos, com um único plano de contribuições e benefícios. Na prática, o Instituto não chegou a ser implementado ${ }^{47}$.

Com o advento, em 1946, de nova Constituição dos Estados Unidos do Brasil $^{48}$, tem registro, pela primeira vez, a expressão previdência social. $\mathrm{O}$ artigo 157 do

regime de paz política e social, as condições necessárias à sua segurança, ao seu bem-estar e à sua prosperidade, decretando a seguinte Constituição, que se cumprirá desde hoje em todo o País.

${ }^{46}$ Decreto-Lei ${ }^{\circ}$ 65, de 14 de dezembro de 1937 que dispõe sobre o recolhimento das contribuições devidas por empregadores e empregados aos Institutos e Caixas de Aposentadorias e Pensões.

${ }^{47}$ MARTINS, Sergio Pinto. Direito da Seguridade Social. 9. ed. São Paulo: Atlas, 1998. p. 35.

48 Disponível em <http://www.planalto.gov.br/ccivil_03/Constituicao/Constituiçao46.htm>, acesso em 12.out.2007. 
texto constitucional é dedicado ao Direito do Trabalho e à previdência, e manteve a triplicidade das fontes de contribuição, já adotada na Carta de 1934 (inciso XVI); foi reconhecido o direito da gestante a assistência durante a gravidez e após o parto, sem prejuízo do salário (inciso X); determinou-se a estabilidade do emprego, rural ou urbano, com indenização do trabalhador despedido (inciso XII); garantiu-se assistência sanitária, hospitalar e médica preventiva, tanto ao trabalhador como à gestante (inciso XIV); previuse o socorro aos desempregados (inciso XV); e a obrigatoriedade da instituição do seguro, pelo empregador em favor do empregado, contra os acidentes de trabalho (inciso XVII).

Em linhas gerais, o texto constitucional de 1946 cuidou de reestruturar o país, após o término do Estado Novo de Vargas. Para tanto, partiu-se dos textos constitucionais de 1891 e 1934. A esse respeito, merece menção a crítica de José Afonso da Silva ${ }^{49}$ :

\begin{abstract}
voltou-se, assim, às fontes formais do passado, que nem sempre estiveram conformes com a história real, o que constituiu o maior erro daquela Carta Magna, que nasceu de costas para o futuro, fitando saudosamente os regimes anteriores, que provaram mal. Talvez isso explique o fato de não ter conseguido realizar-se plenamente. Mas, assim mesmo, não deixou de cumprir sua tarefa de redemocratização, propiciando condições para o desenvolvimento do país durante os vinte anos que o regeu.
\end{abstract}

À época da vigência da Constituição de 1946, há que se destacar os seguintes textos normativos: Decreto $\mathrm{n}^{\mathrm{o}} 35.448$, de $1^{\mathrm{o}}$ de maio de 1954 , que instituiu o Regulamento Geral dos Institutos de Aposentadorias e Pensões e uniformizou as normas aplicáveis a todos os institutos de aposentadorias e pensões; Lei $\mathrm{n}^{\mathrm{o}} 3.807 / 60$, conhecida como Lei Orgânica da Previdência Social (LOPS), que ampliou os benefícios, criando o auxílionatalidade, o auxílio-funeral e o auxílio-reclusão, além de estender a assistência social a inúmeras categorias profissionais; Lei $n^{\circ}$ 4.214, de 2 de março de 1960, que criou o Fundo de Assistência ao Trabalhador Rural (FUNRURAL); Lei $\mathrm{n}^{\circ}$ 4.266/63, instituidora do salário-família; e Decreto no 72, de 21 de novembro de 1966, que unificou os institutos de aposentadoria e pensões, centralizando a organização previdenciária no Instituto Nacional da Previdência Social (INPS) ${ }^{50}$.

No dia 31 de março de 1964, à força, instaura-se o governo do Comando Militar Revolucionário. Foi época de prisões políticas de todos quantos seguiram o

\footnotetext{
${ }^{49}$ SILVA, José Afonso da. Curso de Direito Constitucional Positivo. 10. ed. São Paulo: Malheiros, 1995. p. 86.

${ }^{50}$ MARTINS, Sergio Pinto. Direito da Seguridade Social. 9. ed. São Paulo: Atlas, 1998. p. 36-7.
} 
Presidente deposto ou com ele simplesmente simpatizavam, ou com idéias de esquerda, ou apenas protestavam contra o autoritarismo implantado. De março de 1964 a janeiro de 1967 governou-se mediante a edição de quatro atos institucionais e trinta e sete atos complementares, que tornaram incompulsável o Direito Constitucional então vigente ${ }^{51}$.

Em 24 de janeiro de 1967 o governo militar promulga a Constituição do Brasil $^{52}$. Ideologicamente, o texto ${ }^{53}$ preocupou-se com a segurança nacional, e sofreu grande influência da Carta de 1937, centralizando poderes na União e na figura do Presidente da República ${ }^{54}$.

Concernente à seguridade social, foi repetido, no artigo 158, com modificações de pouca relevância, o texto da Constituição de 1937. Infraconstitucionalmente, o sistema de seguro de acidente de trabalho foi integrado ao sistema previdenciário (Decreto $\mathrm{n}^{\circ} 5.316$ de 14 de setembro de 1967) e as empresas passaram a recolher a contribuição previdenciária sobre o trabalho autônomo (Decreto-lei n ${ }^{\circ}$ 959, de 13 de outubro de 1969) ${ }^{55}$.

Em 17 de outubro de 1969 promulgou-se a Emenda Constitucional n ${ }^{\text {1 }}$ 1/69. A matéria previdenciária ainda foi tratada em conjunto com a de Direito do Trabalho. $\mathrm{O}$ artigo 165 previu: o salário-família aos dependentes (inciso II); o descanso remunerado da gestante, antes e depois do parto, sem prejuízo do salário (inciso XI); a forma tríplice de custeio - União, empregador e empregado -, bem como institutos de previdência no caso de velhice, doença, invalidez, morte, desemprego e acidente de trabalho (inciso XVI); e aposentadoria da mulher com 30 (trinta) anos de trabalho, com rendimentos integrais (inciso XIX).

Os trabalhadores domésticos passaram a ser segurados obrigatórios, nos termos da Lei $n^{\circ} 5.859 / 72$. A Lei $n^{\circ} 5.890 / 73$ trouxe nova Lei Orgânica da Previdência Social (LOPS). O salário-maternidade foi incluído entre os benefícios previdenciários (Lei $\mathrm{n}^{\circ}$

${ }^{51}$ SILVA, José Afonso da. Curso de Direito Constitucional Positivo. 10. ed. São Paulo: Malheiros, 1995. p. 86-7.

${ }^{52} \mathrm{O}$ nome, posteriormente, foi alterado para Constituição da República Federativa do Brasil pela Emenda Constitucional $\mathrm{n}^{\circ} 1 / 69$.

53 Disponível em <http://www.planalto.gov.br/ccivil_03/Constituicao/Constituiçao67.htm>, acesso em 12.out.2007.

${ }^{54}$ No que se refere ao direito laboral, ao compará-la com a Constituição de 1946 aduz José Afonso da Silva que definiu mais eficazmente os direitos dos trabalhadores (SILVA, José Afonso da. Curso de Direito Constitucional Positivo. 10. ed. São Paulo: Malheiros, 1995. p. 88).

${ }^{55}$ MARTINS, Sergio Pinto. Direito da Seguridade Social. 9. ed. São Paulo: Atlas, 1998. p. 36-7. 
6.136/74). Foi editada a Consolidação das Leis da Previdência Social (CLPS), pelo Decreto $n^{\circ} 77.077 / 76$, e instituído o Sistema Nacional de Previdência e Assistência Social (SINPAS) pela Lei $n^{\circ}$ 6.439/77. Os Decretos $n^{\circ} 83.080 / 79$ e $n^{\circ} 83.081 / 79$ criaram o Regulamento de Benefícios da Previdência Social (RBPS) e o Regulamento de Custeio da Previdência Social (RCPS). Em 1981, pela Emenda Constitucional no 18, acrescentou-se o inciso XX ao artigo 158 do texto constitucional, a fim de garantir aos professores e professoras aposentadoria com 30 (trinta) e 25 (vinte e cinco) anos de exercício do magistério, respectivamente. Adveio nova Consolidação das Leis da Previdência Social (CLPS), instituída pelo Decreto n ${ }^{\circ} 89.312 / 84$. Criou-se o seguro-desemprego (Decreto-lei $\left.n^{\circ} 2.283 / 86\right)^{56}$.

Sob os auspícios da Constituição de 1967, alterada pela Emenda Constitucional $\mathrm{n}^{\mathrm{o}} 1 / 69^{57}$, a clientela da Previdência Social expandiu-se enormemente, não só pela incorporação de novas categorias (...) mas porque o crescimento econômico fez emergir grandes contingentes de assalariados dos mais diversos níveis, todos obrigados à filiação ${ }^{58}$.

Em que pese um ou outro movimento de regressão, como por exemplo o retrocesso do texto de 1937 em relação ao de 1934, é possível divisar uma linha evolutiva na qualidade e quantidade dos instrumentos de proteção social, desde a Constituição de 1824 até os dias atuais. Tem-se claro, assim, que os direitos sociais, entre eles a saúde, previdência e assistência social vieram, ao longo dos textos constitucionais e também por normas de hierarquia menor, consolidando-se como parte da cultura social e jurídica brasileira.

A evolução do tratamento legal da matéria levou a Assembléia Constituinte a promulgar, em 5 de outubro de 1988, o texto constitucional que mais fez menção aos direitos sociais de toda a breve história de nossas constituições. Ficam demonstradas, assim, as origens da tutela ao sistema de proteção social, atualmente conhecida como

\footnotetext{
${ }^{56}$ MARTINS, Sergio Pinto. Direito da Seguridade Social. 9. ed. São Paulo: Atlas, 1998. p. 37-8.

57 Teórica e tecnicamente não se tratou de emenda, mas de nova constituição. A emenda só serviu como mecanismo de outorga, uma vez que verdadeiramente se promulgou texto integralmente reformulado (...) (SILVA, José Afonso da. Curso de Direito Constitucional Positivo. 10. ed. São Paulo: Malheiros, 1995. p. $88)$.

58 VIANNA, Maria Lucia T. Werneck. Articulação de Interesses, Estratégias de Bem-estar e Políticas Públicas: A Americanização (perversa) da Seguridade Social no Brasil. Tese de Doutorado. Instituto Universitário de Pesquisas do Rio de Janeiro, Rio de Janeiro, 1995. p. 149.
} 
seguridade social, que é gênero, do qual são espécies o amparo à saúde, a previdência e a assistência social.

\subsection{A base constitucional atual}

Logo no artigo $1^{\text {o }}$ da Constituição da República ${ }^{59}$ os valores sociais do trabalho são citados como fundamentos da República Federativa do Brasil. No artigo $3^{\circ}$, aparece como objetivo construir uma sociedade livre, justa e solidária.

Nos artigos $6^{\circ}$ e $7^{\circ}$ lê-se:

Art. $6^{\circ}$. São direitos sociais a educação, a saúde, o trabalho, a moradia, o lazer, a segurança, a previdência social, a proteção à maternidade e à infância, a assistência aos desamparados, na forma desta Constituição.

Art. $7^{\circ}$. São direitos dos trabalhadores urbanos e rurais, além de outros que visem à melhoria de sua condição social:

(...)

II - seguro-desemprego, em caso de desemprego involuntário;

(...)

IV - salário mínimo, fixado em lei, nacionalmente unificado, capaz de atender a suas necessidades vitais básicas e às de sua família com moradia, alimentação, educação, saúde, lazer, vestuário, higiene, transporte e previdência social, com reajustes periódicos que lhe preservem o poder aquisitivo, sendo vedada sua vinculação para qualquer fim;

(...)

XII - salário-família pago em razão do dependente do trabalhador de baixa renda nos termos da lei;

(...)

XXIV - aposentadoria;

(...)

XXVIII - seguro contra acidentes de trabalho, a cargo do empregador, sem excluir a indenização a que este está obrigado, quando incorrer em dolo ou culpa;

Com relação aos servidores públicos efetivos, dispõem os artigos 40 e 149:

Art. 40. Aos servidores titulares de cargos efetivos da União, dos Estados, do Distrito Federal e dos Municípios, incluídas suas autarquias e fundações, é assegurado regime de previdência de caráter contributivo e solidário, mediante contribuição do respectivo ente público, dos servidores ativos e inativos e dos pensionistas, observados critérios que preservem o equilíbrio financeiro e atuarial e o disposto neste artigo.

59 Disponível em <http://www.planalto.gov.br/ccivil_03/Constituicao/Constituiçao.htm>, acesso em 20.jul.2007. 
Art. 149. Compete exclusivamente à União instituir contribuições sociais, de intervenção no domínio econômico e de interesse das categorias profissionais ou econômicas, como instrumento de sua atuação nas respectivas áreas, observado o disposto nos arts. 146, III, e 150, I e III, e sem prejuízo do previsto no art. 195, § $6^{\circ}$, relativamente às contribuições a que alude o dispositivo.

$\S 1^{\circ}$ Os Estados, o Distrito Federal e os Municípios instituirão contribuição, cobrada de seus servidores, para o custeio, em benefício destes, do regime previdenciário de que trata o art. 40, cuja alíquota não será inferior à da contribuição dos servidores titulares de cargos efetivos da União.

$(\ldots)$

Tal como consta do texto constitucional atual, a seguridade social compreende integrado conjunto de ações, a cargo dos poderes públicos, mas também de toda a sociedade, a fim de garantir saúde ${ }^{60}$, previdência e assistência social (artigo 194). Esse feixe de ações parte do princípio de uma concepção de asseguração plena, a fim de que o indivíduo seja considerado sujeito de direitos sociais, protegido das vicissitudes da vida a fim de que possa - a salvo de contratempos - desenvolver-se tanto quanto lhe seja possível, num ambiente de segurança. Para Arthur Bragança de Vasconcellos Weintraub e Juliano Sarmento Barra, o cerne dessa segurança é a dignidade da pessoa humana, dignidade a persistir em eventos de morte, doença, invalidez, desemprego, velhice e gestação ${ }^{61}$.

Trata-se, sem dúvida, de uma concepção protetora, que busca completo abrigo e arrimo a todos os indivíduos, indistintamente. Essa conclusão se extrai dos incisos I e II do artigo 194 da Constituição Federal de 1988, que prevêem expressamente a universalidade da cobertura e do atendimento da seguridade social, igualmente nas zonas urbana e rural. Ao lado dos objetivos já citados, também balizam o sistema de seguridade social a seletividade e distributividade na prestação dos benefícios e serviços; a irredutibilidade do valor dos benefícios; a eqüidade na forma de participação no custeio; a diversidade da base de financiamento e o caráter democrático e descentralizado da administração, mediante gestão quadripartite ${ }^{62}$.

\footnotetext{
${ }^{60}$ Nos termos do artigo 196 da Constituição, a saúde é direito de todos e dever do Estado, garantido mediante políticas sociais e econômicas que visem à redução do risco de doença e de outros agravos e ao acesso universal e igualitário às ações e serviços para sua promoção, proteção e recuperação.

${ }^{61}$ WEINTRAUB, Arthur Bragança de Vasconcellos e BARRA, Juliano Sarmento. Direito sanitário previdenciário e trabalhista. São Paulo: Quartier Latin, 2006. p. 22.

${ }^{62}$ Mediante participação dos trabalhadores, dos empregadores, dos aposentados e do Governo nos órgãos colegiados.
} 
O custeio da seguridade social, nos termos do texto constitucional, cabe a toda a sociedade. Além de recursos provenientes do orçamento dos entes públicos ${ }^{63}$ a sociedade civil financia o sistema de seguridade social através das contribuições. São os incisos do artigo 195 que estabelecem quais:

I - do empregador, da empresa e da entidade a ela equiparada na forma da lei, incidentes sobre:

a) a folha de salários e demais rendimentos do trabalho pagos ou creditados, a qualquer título, à pessoa física que lhe preste serviço, mesmo sem vínculo empregatício;

b) a receita ou o faturamento;

c) o lucro;

II - do trabalhador e dos demais segurados da previdência social, não incidindo contribuição sobre aposentadoria e pensão concedidas pelo regime geral de previdência social de que trata $\mathrm{o}$ art. 201;

III - sobre a receita de concursos de prognósticos.

IV - do importador de bens ou serviços do exterior, ou de quem a lei a ele equiparar.

O artigo 195 dá esteio à criminalização das condutas lesivas à arrecadação da seguridade social. É esse dispositivo que cria, constitucionalmente, a obrigação previdenciária e delimita, com maior precisão, quem são os sujeitos passivos de tal obrigação.

Com relação específica à previdência social, a Constituição a organiza sob $a$ forma de regime geral, de caráter contributivo e de filiação obrigatória, observados critérios que preservem o equilíbrio financeiro e atuarial (artigo 201). Cabe destacar, novamente, que o texto constitucional abre as portas para a criminalização quando se refere ao equilíbrio financeiro e atuarial. Só é possível atingir o equilíbrio garantindo o aporte de recursos ao sistema, que será reforçado pela criminalização das condutas que esvaziam a arrecadação.

Os benefícios previstos constitucionalmente são as coberturas no caso de doença, invalidez, morte e idade avançada (inciso I); a proteção à gestante (inciso II) e ao trabalhador em estado involuntário de desemprego (inciso III); além do salário-família (inciso IV), auxílio-reclusão (inciso IV) e pensão por morte (inciso V).

\footnotetext{
${ }^{63}$ União, Estados, Distrito Federal e Municípios. Ressalte-se que de acordo com o $\S 1^{\circ}$ do artigo 195 , as receitas dos Estados, do Distrito Federal e dos Municípios destinadas à seguridade social constarão dos respectivos orçamentos, não integrando o orçamento da União.
} 
No que concerne à assistência social, será prestada a quem dela necessitar, independentemente de contribuição à seguridade social (artigo 203). São objetivos da assistência social:

\footnotetext{
I - a proteção à família, à maternidade, à infância, à adolescência e à velhice;

II - o amparo às crianças e adolescentes carentes;

III - a promoção da integração ao mercado de trabalho;

IV - a habilitação e reabilitação das pessoas portadoras de deficiência e a promoção de sua integração à vida comunitária;

V - a garantia de um salário mínimo de benefício mensal à pessoa portadora de deficiência e ao idoso que comprovem não possuir meios de prover à própria manutenção ou de tê-la provida por sua família, conforme dispuser a lei.
}

Extrai-se, portanto, da análise do texto constitucional, ser a seguridade social fundeada em três pilares: a previdência social, a saúde e a assistência social. Entre elas a nota diferencial está na necessidade de contribuição para o gozo da previdência, já que a promoção da saúde e a assistência social são prestadas em caráter amplo e universal pois independem, para sua fruição, de qualquer contraprestação.

$\mathrm{O}$ atual sistema de seguridade, que se caracteriza como um amplo e universal espectro de benefícios, tem inegáveis méritos. Por outro lado, há que ser custeado, trazendo ônus financeiros para vários atores, que nem sempre enxergam o caráter social e comunitário da contribuição que lhes toca. Cabe, aqui, uma breve elucubração. Ouve-se de pessoas mais ou menos esclarecidas que o sistema de seguridade social não traz benefícios a toda a sociedade, mas serve apenas à parcela menos provida financeiramente ${ }^{64}$, que não tem condições de pagar por serviços particulares de saúde ou previdência. Opiniões desse calibre merecem ser revistas.

Tome-se, por exemplo, a saúde. Embora muitas pessoas não sejam usuárias diretas do sistema público de saúde, pois têm possibilidade financeira de custear convênios ou médicos particulares, os bons resultados de um programa de saúde pública aproveitam a toda a sociedade. Por exemplo, no controle de epidemias, zoonoses e doenças infectocontagiosas. A própria empresa, uma indústria, verbi gratia, inserida num contexto de

${ }^{64}$ O termo que sintetiza o sujeito amparado pela Assistência Social é a miserabilidade. O critério para definir a condição de miserável é político, mas podemos definir o miserável como aquela pessoa que não consegue obter por sua conta um mínimo para sobreviver com dignidade, devendo ser amparado pelo Estado (WEINTRAUB, Arthur Bragança de Vasconcellos e BARRA, Juliano Sarmento. Direito sanitário previdenciário e trabalhista. São Paulo: Quartier Latin, 2006. p. 29). 
assistência governamental à saúde bem sucedida, tem operários mais bem dispostos e assíduos.

Todos os cidadãos, inclusive quem não é usuário direito do sistema de seguridade, acabam por ter majorada a qualidade do convívio social com um programa efetivo de assistência social. Deflui daí, também, a possibilidade de se estender a contribuição para o custeio do sistema a toda a sociedade como, aliás, faz o caput do artigo 194 da Constituição da República.

2.3 Natureza jurídica das contribuições previdenciárias

Muito já se debateu acerca da natureza jurídica da contribuição previdenciária. Hoje a doutrina, acompanhada pela grande maioria dos julgados, a considera espécie do gênero tributo, ao lado dos impostos, taxas, empréstimos compulsórios e contribuições de melhoria. Assim,

é relativamente pacífica a aceitação das contribuições sociais como tributo ${ }^{65}$. Com o advento da Constituição de 1988, a natureza tributária das contribuições a que se refere o seu art. 149 - das quais as da seguridade social fazem parte - é reconhecida tanto pela jurisprudência como pela maioria da doutrina ${ }^{66}$.

Há, ainda, quem deduza a natureza jurídica das contribuições pelas regras gerais às quais ela está vinculada: nos termos do art. 149 da CF, as contribuições parafiscais em geral estão submetidas aos princípios vetores da tributação e às normas gerais do Direito Tributário, isto é, ao CTN. São, pois, ontológica e normativamente tributos $^{67}$.

Diante da similitude que se aponta adquire pertinência, portanto, a seguinte indagação: uma vez que a contribuição previdenciária é espécie de tributo, qual razão levou o legislador penal a instituir pela Lei $n^{\circ} 9.983$ de 14 de julho de 2000 tipos penais específicos para a punição dos crimes contra a seguridade social? Sendo as contribuições

\footnotetext{
${ }^{65}$ TAVARES, Marcelo Leonardo. Direito Previdenciário. 5. ed. Rio de Janeiro: Lumen Juris, 2003. p. 3.

${ }^{66}$ PIERDONÁ, Zélia Luiza. Contribuições para a Seguridade Social. São Paulo: LTr, 2003. p. 21.

${ }^{67}$ COÊLHO, Sacha Calmon Navarro. Comentários à Constituição de 1988: sistema tributário. 3. ed. Rio de Janeiro: Forense, 1991. p. 169.
} 
espécie de tributo, não estariam tais condutas suficientemente coibidas pelos artigos $1^{\circ}$ e $2^{\circ}$ da Lei ${ }^{\circ} 8.137 / 90$ que, como é sabido, cuidam dos crimes contra a ordem tributária ${ }^{68}$ ?

O enfrentamento da questão, ao que parece, admite três respostas possíveis, que não se excluem, mas se complementam. A primeira, de caráter costumeiro: há tempos, desde o Decreto-Lei n ${ }^{\circ}$ 65, de 14 de dezembro de 1937, por seu artigo 5º legislador penal pátrio opta por construir tipo incriminador apartado para as lesões contra a previdência, quiçá pelo caráter didático e preventivo, com intuito de explicitar o exato alcance da norma. Em segundo lugar pode-se apontar a especificidade da maneira pela qual se faz o custeio da previdência, já que o recolhimento realizado pelo empregador compreende duas parcelas - a que ele próprio deve e a devida pelo empregado - que lhe é descontada e repassada aos cofres públicos pelo empregador. Tal forma de recolhimento compartilhado é característica da contribuição previdenciária e demanda a construção de tipos penais específicos, que atendam à dinâmica de sua rotina fiscal. Por fim, e conforme mencionado, já grassou muita dúvida acerca da inclusão da contribuição previdenciária entre os tributos, e se hoje tal natureza é pacífica, não o era outrora.

O fato é que atualmente os chamados crimes previdenciários possuem regulamentação própria, embora suas penas, como regra, sejam exatamente as mesmas daquelas cominadas aos crimes tributários. A equiparação é saudável, na medida em que as condutas dos crimes fiscais e crimes previdenciários são muito próximas. Fica prestigiado, assim, o critério da proporcionalidade que deve se estabelecer entre as sanções penais.

\footnotetext{
${ }^{68}$ Com visão crítica, analisando a Lei $n^{0}$ 9.983/00, Heloisa Estellita Salomão chega a defender a desnecessidade da existência de tipos penais específicos para os crimes contra a arrecadação da seguridade social: (...) ousamos afirmar, ainda, totalmente desnecessária [a nova lei], uma vez que as condutas ali descritas encontram perfeita adequação naquelas já descritas nos arts. $1^{o}$ e $2^{o}$ da L. $8.137 / 90$ e com superioridade técnica, inclusive (SALOMÃO, Heloisa Estellita. Extinção da punibilidade pelo pagamento nos crimes tributários e previdenciários após o advento da lei 9.983/00. Revista Síntese de Direito Penal e Processual Penal. Porto Alegre. v. 2, n. 8, p. 63-5, jun./jul. 2001).
} 


\title{
3 CRIMES CONTRA A SEGURIDADE SOCIAL
}

\author{
3.1 Necessária introdução: bem jurídico penal
}

\subsubsection{Origens e conceito}

Mostra-se útil, antes de enfrentar a questão do bem jurídico tutelado pelos crimes contra a arrecadação previdenciária, estabelecer, em breves linhas, estudo acerca do que esse instituto de direito significa, tomadas algumas nuances de sua evolução e aspectos históricos, já que ${ }^{69}$,

\begin{abstract}
a noção de bem jurídico desempenha relevante papel em um Estado de Direito democrático e social, pois define a função do Direito Penal e estabelece os limites do jus puniendi (...) Sendo assim, os bens jurídicos estão na base da criação dos tipos penais que resultam da necessidade de proteção daqueles bens indispensáveis ao convívio ordenado dos homens.O legislador, ao configurar os tipos, descreve condutas que, em tese, são ilícitos porque atentam contra bens e interesses considerados indispensáveis à sociedade.
\end{abstract}

A importância do tema parece ser unanimidade entre os estudiosos, porque $o$ Direito Penal hodierno não pode prescindir de instrumentos garantidores da liberdade, que limitem o poder criminalizador do Estado $(. . .)^{70}$, e também: não se concebe a existência de uma conduta típica que não afete um bem jurídico, posto que os tipos não passam da particulares manifestações de tutela jurídica desses bens ${ }^{71}$.

Miguel Reale Júnior, imputa ao bem jurídico relevante função, pois ele auxilia a definir, dentre múltiplas formas que a conduta possa apresentar, qual aquela especial que, dadas suas características, exige-se seja reprimida com mais eficácia, ou por meio da sanção penal ou por meio da sanção administrativa ${ }^{72}$.

69 BARETTA, Gilciane Allen. Os crimes fiscais e previdenciários. A extinção da punibilidade. Belo Horizonte: Mandamentos, 2004. p. 85.

${ }^{70}$ COELHO, Yuri Carneiro. Bem jurídico-penal. Belo Horizonte: Mandamentos, 2003. p. 59.

71 ZAFFARONI, Eugenio Raúl; PIERANGELI, José Henrique. Manual de Direito Penal Brasileiro: parte geral. 5. ed. São Paulo: Revista dos Tribunais, 2004. p.439.

${ }^{72}$ REALE JÚNIOR. Miguel. Despenalização no direito penal econômico: uma terceira via entre o crime e a infração administrativa? Revista Brasileira de Ciências Criminais, São Paulo, v. 7, n. 28, p. 116-129, out./dez. 1999. 
Sob os auspícios do iluminismo, o conceito de delito passa a ser fundado na violação do contrato social. Com a filosofia iluminista, procurou-se romper com o absolutismo que justificava o uso do Direito Penal para defender a religião, os costumes, o príncipe, e todo o mais que este entendesse relevante, ao seu bel prazer - e, diga-se de passagem, sem qualquer limitação. Busca-se, então, um conceito material de delito, preenchido de significado, expurgando do âmbito do Direito Penal a punição de condutas que contrariassem preceitos de natureza puramente religiosa e formal ${ }^{73}$.

Nas palavras de Evandro Pelarin ${ }^{74}$

o iluminismo detonou o processo de construção da noção do bem jurídico-penal, e com (talvez mais) importantes limites formais e até mesmo materiais ao ius puniendi, com a potencialização do clássico princípio da legalidade e seus corolários e a necessidade, para a existência do crime, da lesão a um direito subjetivo e a danosidade social, a tentar afastar a punição das condutas moralmente reprováveis ou contrárias à religião, mas que não causassem um dano diretamente a uma pessoa em concreto ou à própria república.

Grande parte - quase a unanimidade - dos estudiosos do Direito Penal afirma ser Johann Anselm Feuerbach o idealizador do instituto bem jurídico como limitador do recurso ao Direito Penal ${ }^{75}$, já que este consiste na arma mais poderosa e incisiva de que se pode valer o Estado, pois priva os indivíduos de sua liberdade, que certamente constituiu um dos mais importantes direitos fundamentais.

Seguindo a linha de raciocínio inaugurado por Feuerbach, Karl Binding sustenta, em apertada síntese, que não é todo e qualquer bem que o Direito Penal pode proteger, mas apenas e tão-somente aqueles que tenham relevância jurídica, ou seja, os bens jurídicos ${ }^{76}$. Binding, adepto do positivismo jurídico, concebia o bem jurídico como tudo o que, aos olhos do legislador, tem valor como condição de uma vida saudável dos

\footnotetext{
${ }^{73}$ COELHO, Yuri Carneiro. Bem jurídico-penal. Belo Horizonte: Mandamentos, 2003. p. 31.

74 PELARIN, Evandro. Bem jurídico-penal. Um debate sobre a descriminalização. São Paulo: IBCCRIM, 2002. p. 38-9.

${ }^{75}$ Evandro Pelarin, aludindo às lições de Manuel da Costa Andrade, afirma que Birnbaum (...) teria iniciado de maneira sistemática a teoria do bem jurídico (PELARIN, Evandro. Bem jurídico-penal. Um debate sobre a descriminalização. São Paulo: IBCCRIM, 2002. p. 54).

${ }^{76}$ PASCHOAL, Janaina Conceição. Constituição, Criminalização e Direito Penal Mínimo. São Paulo: RT, 2003. p. 30.
} 
cidadãos, de tal maneira que o bem jurídico se identifica com tudo o que como tal for considerado pelo legislador ${ }^{77}$.

Respectiva concepção é alvo de severas críticas, em razão de sua lógica puramente formal, destituída de conteúdo valorativo. Nas palavras de Paulo Ferreira da Cunha, sendo a norma a única e definitiva fonte de revelação do bem jurídico, o conceito abandona qualquer pretensão de legitimação material, de limite à liberdade criminalizadora/descriminalizadora do legislador, qualquer função orientadora e crítica. Sob a ótica de Gerardo Barbosa Castillo e Carlo Arturo Gómez Pavajeau, essa definição reducionista do bem jurídico afasta de modo perigoso o estudo acerca da danosidade penal, já que a escolha do bem jurídico deixa de ser um instrumento de consenso social, e fica entregue à decisão - eventualmente arbitrária - do legislador. Advertem os autores que tal teoria veio a ser posteriormente utilizada pelo direito penal nacional-socialista alemão ${ }^{78}$.

Para Franz von Liszt ${ }^{79}$,

chamamos bens jurídicos os interesses que o direito protege. Bem jurídico é, pois, o interesse juridicamente protegido. Todos os bens jurídicos são interesses humanos, ou do indivíduo ou da collectividade. É a vida, e não o direito, que produz o interesse; mas só a proteção jurídica converte o interesse em bem jurídico. A liberdade individual, a inviolabilidade do domicílio e o segredo epistolar eram interesses muito antes que as cartas constitucionais os garantisses contra a intervenção arbitrária do poder público ${ }^{80}$.

É interessante e muito elucidativa a concepção do autor acerca da origem do bem jurídico: são as relações entre os indivíduos entre si ou entre estes e o Estado que fariam surgir os interesses e necessidades sociais e por conseqüência, os bens jurídicos. A partir daí, a vontade geral, que paira acima da vontade individual, toma a si esta missão, e

\footnotetext{
${ }^{77}$ Evandro Pelarin, com esteio em Manuel da Costa Andrade. (PELARIN, Evandro. Bem jurídico-penal. Um debate sobre a descriminalização. São Paulo: IBCCRIM, 2002. p. 65).

${ }^{78}$ PELARIN, Evandro. Bem jurídico-penal. Um debate sobre a descriminalização. São Paulo: IBCCRIM, 2002. p. 67.

${ }^{79}$ LISZT, Franz von. Tratado de Direito Penal allemão. trad. José Hygino Duarte Pereira. Brasília: Senado Federal, 2006. p. 93-4 (grafia original da tradução).

${ }^{80}$ Em sentido muito próximo: o direito institucionaliza, via comandos normativos, o proibido e o permitido, que inconscientemente e em latência já atuavam de certo modo no meio social (REALE JÚNIOR, Miguel. Teoria do Delito. 2. ed. São Paulo: RT, 2000. p. 19).
} 
a desempenha estabelecendo a ordem jurídica ${ }^{81}$, isto é, discriminando os interesses legítimos e autorisados dos que não o são ${ }^{82}$.

Por derradeiro, cabe destacar concepção derivada do pensamento neokantiano, que identifica o bem jurídico como um valor abstrato e direcionado à busca da ratio essendi da norma penal. Nessa linha de pensamento, o bem jurídico é tido como elemento de interpretação da norma penal, sistema de partida para compreensão da ratio legis normativa. Contra tal modelo, com acerto, insurge-se Yuri Carneiro Coelho, pois essa postura eminentemente valorativa, "espiritualizando" seu conceito, termina por deixá-lo vazio, sem perspectiva de determinação de sua natureza material e sem elementos de fundo crítico que permitam a limitação do jus puniendi estatal ${ }^{83}$.

Muito embora o funcionalismo ${ }^{84}$ alemão, considerado por muitos como a inevitável superação do finalismo de $\mathrm{Welzel}^{85}$, por um de seus principais representantes, Güntuer Jakobs, conteste a utilidade dos bens jurídicos ${ }^{86}{ }^{87}$, é fato inegável que o Direito Penal brasileiro está, todo ele, organizado ao redor de bens jurídicos. A esse respeito, valiosa é a contribuição de David Teixeira de Azevedo que, com esteio em Hasn Joachim Hirsch, aponta a crise que atravessa o instituto:

\footnotetext{
${ }^{81}$ Apontando a mutabilidade dos interesses sociais e, por consequiência, do rol de bens jurídicos: (...) em cada situação histórica e social de um grupo humano, os pressupostos imprescindíveis para uma existência em comum se concretizam nos chamados bens jurídicos. Cabe, sem dúvida, ao Direito Penal garanti-los e punir sua violação em determinadas hipóteses. (BARETTA, Gilciane Allen. Os crimes fiscais e previdenciários. A extinção da punibilidade. Belo Horizonte: Mandamentos, 2004. p. 86).

${ }^{82}$ LISZT, Franz von. Tratado de Direito Penal allemão. trad. José Hygino Duarte Pereira. Brasília: Senado Federal, 2006. p. 96 (grafia original da tradução).

${ }^{83}$ COELHO, Yuri Carneiro. Bem jurídico-penal. Belo Horizonte: Mandamentos, 2003. p. 56.

${ }^{84}$ As teorias do funcionalismo sistêmico partem, unanimemente, das formulações teóricas de Parson e Luhmann, que descrevem o sistema social enquanto um sistema que agrega funções para sua autosobrevivência, funções estas que devem ser realizadas de forma adequada. Ocorrendo o fenômeno da disfuncionalidade, surge a necessidade de se corrigir a conduta disfuncional e reorientá-la para uma condição de funcionalidade sistêmica. A forma mais grave de disfuncionalidade é aquela que implica na prática de uma conduta típica para o Direito Penal (COELHO, Yuri Carneiro. Bem jurídico-penal. Belo Horizonte: Mandamentos, 2003. p. 65).

${ }^{85}$ WELZEL, Hans. Novo sistema jurídico penal. trad. Luiz Regis Prado. São Paulo: RT, 2001.

${ }^{86}$ (...) el Derecho Penal ya no garantiza la existencia de los bienes jurídicos em sí, sino solo que las personas no ataquen esos bienes, y, de manera correspondiente, únicamente em esta medida se tratará de bienes jurídicos (...) el Derecho no es um muro colocado alrededor de los bienes, sino que el Derecho es la estructura de la relación entre personas (JAKOBS, Günther. ¿Qué protege el Derecho Penal: bienes jurídicos o la vigência de la norma? Mendoza: Cuyo. p. 14-5).

${ }^{87}$ Com efeito, é a face mais radical do funcionalismo, atribuída a Günther Jacobs, que prescinde totalmente da idéia de bem jurídico penal, retrocedendo a um Direito Penal exclusivamente formal e potencialmente arbitrário, já que ilimitado (PASCHOAL, Janaina Conceição. Constituição, Criminalização e Direito Penal Mínimo. São Paulo: RT, 2003. p. 38).
} 
o bem jurídico modernamente, contudo, encontra-se em crise. A doutrina critica sua capacidade de rendimento, especialmente em face dos denominados bens jurídicos universais, que não reclamam uma individualização e, também, em face dos bens jurídicos fluidos ou imateriais, que não demandam uma concretização do objeto de tutela, definindo-se como um "contexto de vida" ou referidos ao futuro, o que significa um processo contínuo de desmaterialização do bem jurídico.

Conclui, entretanto, pela inviabilidade de se afastá-lo, dadas as suas imprescindíveis contribuições ao estudo do Direito Penal, por desempenhar insubstituível papel dogmático, sistemático e político criminal; por constituir categoria de ligadura no seio das categorias do delito, apresentando-se como valioso ferramental de construção e desconstrução de conceitos dogmáticos, e de elo entre a dogmática e a política criminal. É útil, ainda, pois cumpre função de ferramenta hermenêutica e de identificação do modelo dogmático específico de proibição, por ser instrumento decisivo para a resolução do conflito $(. . .)^{88}$.

Nesta ordem de idéias, seu estudo e correta delimitação é que possibilitam preencher o tipo penal de conteúdo, a fim de que seja fixado o adequado âmbito de proteção da norma.

É a exata determinação do objeto a ser tutelado que serve de limitador à atividade punitiva estatal ${ }^{89}$, garantindo que o Direito Penal consista em via de ultima ratio do ordenamento jurídico, pois se com relação ao controle social informal o Direito exerce papel subsidiário diante das organizações comunitárias ${ }^{90}$, no âmbito do subsistema de controle social formal que se denomina Direito, o Direito Penal é subsidiário em relação aos demais ramos (Civil, Administrativo, Trabalhista).

\footnotetext{
${ }^{88}$ AZEVEDO, David Teixeira. Concurso aparente de normas penais: uma aproximação. Experiências do Direito. Campinas: Millennium, 2004.

${ }^{89}$ Nesse preciso sentido: (...) apesar das controvérsias relativas ao bem jurídico penal, desde os primórdios, tal instituto traz, em seu bojo, uma idéia de limitação, ou, pelo menos, de busca de limitação ao poder de punir do Estado (PASCHOAL, Janaina Conceição. Constituição, Criminalização e Direito Penal Mínimo. São Paulo: RT, 2003. p. 48).

${ }^{90}$ Neste exato sentido Miguel Reale Júnior: O controle social exerce-se, primeiramente, por via da família, da escola, da igreja, do sindicato, atuantes na tarefa de socializar o indivíduo levando-o a adotar os valores socialmente reconhecidos e os respeitar, independentemente da ação ameaçadora e repressiva do Direito Penal, que constitui uma espécie de controle social, mas de caráter formal e residual, pois só atua diante do fracasso dos instrumentos informais de controle (Instituições de Direito Penal. v. I. 2. ed. Rio de Janeiro: Forense, 2004. p. 3).
} 
Conceituam Zaffaroni e Pierangeli: bem jurídico penalmente tutelado é a relação de disponibilidade de um indivíduo com um objeto, protegido pelo Estado, que revela seu interesse mediante a tipificação penal de condutas que o afetam ${ }^{91}$.

$$
\text { Para Santiago Mir Puig }{ }^{92}
$$

os interesses sociais que por sua importância merecem a proteção do Direito são chamados 'bens jurídicos' (...) e para que os referidos bens jurídicos mereçam proteção penal e sejam considerados bens jurídico-penais, será preciso que tenham uma 'importância fundamental'.

Resta evidente, assim, que não se pode pretender estudar qualquer tipo penal sem, antes, buscar a essência de proteção da norma, ou seja, estabelecer, com o maior grau possível de acuidade, o bem jurídico tutelado. É de tal ônus que, a seguir, o presente estudo pretende se desimcumbir.

\subsubsection{O que protegem os crimes contra a seguridade social?}

Gilciane Allen Baretta, valendo-se das lições de Jorge de Figueiredo Dias, define bem jurídico como a expressão de um interesse, da pessoa ou da comunidade, na manutenção ou integridade de um certo estado, objeto ou bem em si mesmo socialmente relevante e por isso reconhecido como valioso ${ }^{93}$. Qual é o bem valioso tutelado pelas normas dos artigos 168-A (apropriação indébita previdenciária) e 337-A (sonegação de contribuição previdenciária) do Código Penal?

A previdência social constitui espécie do gênero seguridade social, que compreende também a saúde e a assistência social ${ }^{94}$.

Mais certo, portanto, seria adotar a nomenclatura crimes contra a seguridade social, já que a diminuição da arrecadação ocasionada pela apropriação indébita previdenciária (Código Penal, artigo 168-A) ou a sonegação de contribuição previdenciária

\footnotetext{
91 ZAFFARONI, Eugenio Raúl; PIERANGELI, José Henrique. Manual de Direito Penal Brasileiro: parte geral. 5. ed. São Paulo: Revista dos Tribunais, 2004. p. 439.

92 MIR PUIG, Santiago. Direito Penal. Fundamentos e Teoria do Delito. trad. Cláudia Viana Garcia e José Carlos Nobre Porciúncula Neto. São Paulo: RT, 2007. p. 95-6

93 BARETTA, Gilciane Allen. Os crimes fiscais e previdenciários. A extinção da punibilidade. Belo Horizonte: Mandamentos, 2004. p. 86.

${ }^{94}$ Nesse sentido TAVARES, Marcelo Leonardo. Direito Previdenciário. 5. ed. Rio de Janeiro: Lumen Juris, 2003. p. 1.
} 
(Código Penal, artigo 337-A), irão atingir, em sua totalidade, a seguridade social ${ }^{95}$. Para Fábio Lopes Vilela Berbel, a seguridade social é o conjunto de meios (racionalidade formal) utilizados pela sociedade para atingir a proteção social plena (racionalidade material ${ }^{96}$. Nas palavras de Arthur Bragança de Vasconcellos Weintraub e Juliano Sarmento Barra, Assistência, Saúde e Previdência Social possuem peculiaridades até comuns. Todas podem ter cunho de remediar ou prevenir ${ }^{97}$.

Relativo ao verbete previdência Caldas Aulete $^{98}$ indica como primeiros significados vista ou conhecimento do futuro, precaução, cautela, previsão. Fato é que ao longo dos anos, e diante das vicissitudes do dia a dia e das dificuldades da velhice, mormente a diminuição da força de trabalho e conseqüente perda da qualidade de vida, os Estados se organizaram criando um sistema de mutualismo, em que todos os atores sociais devem suportar o ônus de sustentar o desamparo de alguns. Portanto, o sistema de seguridade social é baseado em uma operação atuarial, por meio da qual se coletam recursos de toda a sociedade, que serão redirecionados a determinados indivíduos, a fim de fazer frente a dificuldades econômicas. Nota-se, pois, um sistema organizado em três tempos, em que há o recolhimento, a administração dos valores e posterior realocação dos recursos, de acordo com critérios previamente estabelecidos.

Ao lado do mutualismo, como uma segunda coluna a fundear e transferir conteúdo valorativo ao sistema de seguridade social, encontra-se a solidariedade, traço de união fraternal que estabelece relações de ajuda entre os indivíduos, não necessariamente recíprocas. Os integrantes de uma relação baseada no mutualismo são ligados por vínculo jurídico que os tornam, ao mesmo tempo, contribuintes e beneficiários. Se o mutualismo representa uma relação de igualdade estrita em que todos os sujeitos envolvidos repartem, na mesma proporção, os aportes e retiradas, o vínculo jurídico colorido pela solidariedade admite tratamento desigual entre seus participantes, para contrabalancear eventuais desigualdades econômicas estranhas e anteriores à redistribuição, ou seja: sujeitos com

\footnotetext{
${ }^{95}$ A Constituição Federal de 1988 trouxe-nos uma completa estruturação da previdência, saúde e assistência social, unificando esses conceitos sob a moderna definição de "seguridade social" (TAVARES. Marcelo Leonardo. Direito Previdenciário. 5. ed. Rio de Janeiro: Lumen Juris, 2003. p. 34).

96 BERBEL, Fábio Lopes Vilela. Teoria Geral da Previdência Social. São Paulo: Quartier Latin, 2005. p. 129.

97 WEINTRAUB, Arthur Bragança de Vasconcellos e BARRA, Juliano Sarmento. Direito sanitário previdenciário e trabalhista. São Paulo: Quartier Latin, 2006. p. 29.

${ }^{98}$ Dicionário Contemporâneo da Língua Portuguesa. v. IV. 5. ed. Rio de Janeiro: Delta, 1964. p. 3261.
} 
maior potencial contributivo carreiam ao sistema recursos mais elevados, com escopo de gerar, ao final, verdadeira compensação.

É consenso que, como ultima ratio do ordenamento jurídico, o Direito Penal deve selecionar cuidadosamente seu objeto de tutela. A criminalização de determinada conduta depende da relevância do bem jurídico lesionado, lógica que traduz a idéia de dignidade penal ${ }^{99}$. A vida, exemplo recorrente, é digna de ser tutelada pelo Direito Penal, assim como indubitavelmente o são a liberdade e a honra. Portanto, é comum ouvir, que há interesses sociais que demandam a resposta intransigente e incisiva que o Direito Penal providencia, na maioria das vezes representada pela pena privativa de liberdade. Quando se verifica tal necessidade pode ser dito que se está diante de um bem jurídico que possui dignidade penal ou estatura penal.

A título ilustrativo, tomem-se as alterações normativas introduzidas pelas Leis $\mathrm{n}^{\circ} 10.826 / 03$ e $\mathrm{n}^{\circ} 11.106 / 05$ : a primeira, adequando a pena às condutas relacionadas ao porte ilegal de arma de fogo, reflexo do aumento de dignidade penal do bem jurídico sob tutela e a última, em sentido inverso, descriminalizando o adultério. Como outro exemplo, citem-se as ações criminosas ligadas às substâncias entorpecentes, que até meados da década de setenta do século passado eram reguladas por um único artigo do Código Penal, o 281. As Leis $n^{\circ}$ 6.368/76 e $n^{\circ}$ 11.343/06 aumentaram, progressivamente, a estatura do bem jurídico protegido, figurando em legislação específica, inclusive com rito procedimental próprio.

Costuma-se marcar como ponto de partida para a análise da dignidade penal de determinado bem jurídico o hierarquicamente mais elevado texto normativo: a constituição. A idéia de interpretar o Direito Penal à luz dos mandamentos constitucionais parte do seguinte pressuposto: uma vez que a atuação do Direito Penal, caso se concretize em uma sentença condenatória, atinge a liberdade, que é garantida constitucionalmente ${ }^{100}$, a escolha dos comportamentos passíveis de sanção penal deve guardar relação com o texto

\footnotetext{
${ }^{99} \mathrm{Na}$ conceituação de Manuel da Costa Andrade, referenciado por Eduardo Reale Ferrari, dignidade penal é o juízo qualificado de intolerância social, demonstrando uma gravosa danosidade social, eliminando, a priori, circunstâncias meramente éticas ou morais (...) (FERRARI, Eduardo Reale. Legislação Penal Antitruste: Direito Penal Econômico e sua Acepção Constitucional. Experiências do Direito. Campinas: Millenium, 2004).

${ }^{100}$ Entre outros dispositivos, cite-se o caput do art. $5^{\circ}$ : Todos são iguais perante a lei, sem distinção de qualquer natureza, garantindo-se aos brasileiros e aos estrangeiros residentes no País a inviolabilidade do direito à vida, à liberdade, à igualdade, à segurança e à propriedade (...) [sem destaque no original].
} 
constitucional. Surge, porém, a seguinte questão: deve a Constituição exercer um controle negativo - admitindo-se apenas a criminalização de condutas que não impliquem desrespeito aos bens jurídicos constitucionalmente protegidos - ou seria a Constituição um limite positivo - autorizando somente a punição das condutas que ofendem os valores albergados pela Constituição ${ }^{101}$ ?

Não resta dúvida, adotada qualquer das óticas de controle recém explanadas, que a seguridade social tem envergadura constitucional, já que expressamente contemplada pelo texto da Carta de 1988. No Brasil, a seguridade social integra as chamadas políticas de estado que, na definição de Floriano de Azevedo Marques Neto ${ }^{102}$ são aquelas definidas, por lei, no processo complexo que envolve o Legislativo e o Executivo. Nelas, vêm consignadas as premissas e objetivos que o Estado brasileiro, num dado momento histórico, quer ver consagrados para um dado setor da economia ou sociedade.

Nos termos do artigo 194, inserido no Título VIII (da Ordem Social), Capítulo II (da Seguridade Social), a seguridade social compreende um conjunto integrado de ações de iniciativa dos Poderes Públicos e da sociedade, destinadas a assegurar os direitos relativos à saúde, à previdência e à assistência social.

Confira-se, por oportuna, a opinião de José Paulo Baltazar Junior ${ }^{103}$, que com esteio em Luis Luisi assevera que:

(...) será, em princípio, legítima a criminalização quando buscar a proteção de um bem jurídico protegido constitucionalmente. Por esse aspecto, inegável a constitucionalidade da criminalização da conduta em exame, que visa a proteger um bem jurídico da maior relevância: a seguridade social, consagrada no art. 194 da Constituição Federal.

Há que se concluir, portanto, que a Constituição de 1988 alberga, como também já fizeram outras ${ }^{104}$, a seguridade social como uma das estratégias da distribuição de saúde, previdência e assistência social.

\footnotetext{
${ }^{101}$ Optando pelo controle positivo e se valendo de elucidativos exemplos: PASCHOAL, Janaina Conceição. Direito Penal. Parte Geral. Barueri: Manole, 2003. p. 13.

${ }^{102}$ MARQUES NETO, Floriano Azevedo. Agências Reguladoras Independentes. Fundamentos e seu Regime Jurídico. Belo Horizonte: Fórum, 2005. p. 85.

${ }^{103}$ BALTAZAR JUNIOR, José Paulo. $O$ crime de omissão no recolhimento de contribuições sociais arrecadadas. Porto Alegre: Livraria do Advogado, 2000. p. 183
} 
A esse respeito, defendendo a arrecadação fiscal como meio de fomentar a justiça social, lição de Luiz Régis Prado:

\begin{abstract}
na matéria em estudo, não há como negar que a sonegação e a fraude fiscal apresentam inegáveis efeitos deletérios no cumprimento das prestações públicas por parte do Estado, como nos programas sociais inseridos no âmbito da Seguridade Social, visando à sedimentação da justiça social ${ }^{105}$.
\end{abstract}

Concluindo parcialmente, pode-se afirmar que a seguridade social tem, certamente - por configurar um conjunto de ações que beneficia toda a sociedade -, envergadura suficiente para ser tutelada pelo Direito Penal. É possível, pois, considerá-la bem jurídico penal.

Inúmeros e contraditórios são os entendimentos acerca do bem jurídico tutelado pelos crimes previdenciários. A multiplicidade de opiniões pode ser explicada por alguns fatores.

Em primeiro lugar, o tempo de criação dos tipos penais. A completa intelecção da norma e de suas características é processo que demanda tempo e reflexão, e o interregno decorrido desde sua criação - pouco mais de sete anos - talvez não tenha sido suficiente para unificar a opinião dos que se debruçam sobre o tema. Por certo que não se trata de norma recém criada, mas a maturidade da interpretação só virá com o passar dos anos. Do mesmo modo, ainda são escassos os casos concretos que galgaram todas as instâncias do Poder Judiciário e aportaram nos Tribunais Superiores. Com o correr dos anos, o entendimento dos Tribunais se irá consolidar ou, ao menos, poder-se-á apontar corrente que predomine sobre as demais.

Outro pormenor que desfavorece o consenso entre os que se dedicam ao estudo da questão é a multidisciplinariedade que ela encerra, já que a norma penal instituidora dos tipos de apropriação indébita previdenciária (Código Penal, artigo 168-A) e sonegação de contribuição previdenciária (Código Penal, artigo 337-A) é da espécie norma penal em branco. Assim, a norma penal apenas incrimina abstratamente, já que a concreta conduta

\footnotetext{
${ }^{104}$ Conferir capítulo 2.1 .

${ }^{105}$ PRADO, Luiz Régis. Curso de Direito Penal Brasileiro. v. 4. 4. ed. São Paulo: RT, 2006. p. 537.
} 
delitiva é descrita e integrada pelo Direito Previdenciário ${ }^{106}$, e há quem até discuta se este se trata de ramo autônomo do Direito ou mero desdobramento do Direito do Trabalho.

Nessa ordem de idéias, impende destacar o grande número de diplomas normativos que tratam da matéria, desde a Constituição da República, passando pelas leis complementares ${ }^{107}$, ordinárias e atos administrativos.

Finalmente, um último fator que traz dissenso é a própria descrição dos tipos objetivos, que os torna, muitas vezes, de difícil inteligência. $\mathrm{E}$ isso acontece, primordialmente, pelas inúmeras formas de custeio e grande número de contribuintes chamados a compor a arrecadação previdenciária.

Alhures, são destacados como bem jurídico dos crimes contra a seguridade social o patrimônio da previdência social; o patrimônio dos cidadãos ligados à previdência social; a ordem tributária; o bom andamento da Administração; os interesses estatais ligados à arrecadação das contribuições previdenciárias e seus acessórios; a "saúde financeira" da seguridade social; o interesse fisco-patrimonial dos órgãos públicos gestores da previdência social; o equilíbrio econômico-financeiro do sistema de seguridade social, a livre concorrência entre as empresas e, por derradeiro, os segurados e beneficiários que tiverem dificuldade em comprovar o período e o valor de suas contribuições.

Encontra-se, na doutrina, ao menos uma dezena de afirmações distintas quando se trata de definir a objetividade jurídica dos crimes previdenciários, isso sem contar com as combinações de que muitas vezes se valem os autores, desdobrando a objetividade jurídica em sucessivos graus.

Aos poucos, entretanto, é possível afastar a maioria das afirmações, quer por derivarem de interpretações que, embora possíveis, não se mostram as mais adequadas ou, até mesmo, por terem seus expositores descurado de elucubrações mais pertinazes. Assim, para que se desvende o bem jurídico por trás dos crimes contra a seguridade social, num primeiro momento será necessário excluir, mediante raciocínio lógico, algumas opiniões.

\footnotetext{
${ }^{106}$ Para Misabel Derzi, em referência de Heloisa Estellita Salomão, a compreensão do injusto penal depende da compreensão do injusto tributário. A mesma autora cita, ainda, lição de Geraldo Ataliba, para quem é preciso considerar que a lei penal não vai incidir diretamente sobre comportamentos ou sobre fatos, mas vai incidir sobre comportamentos e fatos regulados antes pela lei tributária (SALOMÃO, Heloisa Estellita. O crime de não-recolhimento de contribuições previdenciárias. Revista Dialética de Direito Tributário. São Paulo, n. 6, p. 36-47, mar. 2006).

${ }^{107}$ Por exigência do artigo146, III, "d" da Constituição da República.
} 


\title{
3.1.2.1 Patrimônio público como bem jurídico
}

\author{
Afirma-se que
}

o bem jurídico protegido no delito de apropriação indébita previdenciária possui natureza patrimonial. Tutela-se o patrimônio, em primeiro lugar, do Poder Público (Erário ou Fazenda Pública), que é o titular do crédito (contribuição) ou do ato do reembolso (benefício). É o patrimônio que resulta lesado (diminuído). $\mathrm{O}$ delito de apropriação indébita previdenciária sempre ocasiona, em conseqüência, um dano patrimonial, que acaba afetando também e secundariamente os próprios segurados e a livre concorrência das empresas ${ }^{108}$.

E também:

o patrimônio da Previdência Social, portanto, é o bem jurídico tutelado pelo art. 168-A do Código Penal. Destarte, está claro que esse "patrimônio" tutelado no tipo penal do art. 168-A não pertence apenas ao segurado lesado, mas sim, e sobretudo, a toda coletividade. Insta notar, ainda, que num segundo momento, tendo em vista o caráter tributário das contribuições previdenciárias, o tipo do art. 168-A também tutela a própria ordem tributária, já que a contribuição social destinada à Previdência é, ao lado dos impostos e taxas, uma espécie de tributo $^{109}$

o bem jurídico protegido pela norma do art. 337-A do Código Penal é o mesmo do delito de apropriação indébita previdenciária, vale dizer, o patrimônio da previdência social (...) Insta salientar que o bem jurídico protegido é coletivo, supra-individual, na exata medida em que o interesse da "saúde financeira" do sistema da Seguridade Social não interessa apenas a um único cidadão, mas sim a toda a coletividade. Outrossim, levando-se em conta que o art. 337-A foi incluído no capítulo II ("Dos Crimes Praticados por Particular Contra a Administração em Geral") do Título XI ("Dos Crimes Contra a Administração Pública") do Código Penal, podemos concluir, ainda, que aí também se está tutelando o bom andamento da Administração, visto que a irregular escrituração contábil das empresas, no que se refere aos dados exigidos pela Previdência Social, afeta, gravemente, o bom funcionamento da Seguridade Social $^{110}$.

Dos trechos supratranscritos evidencia-se ser o patrimônio do poder público o bem jurídico tutelado pelo crime de apropriação indébita previdenciária, pelo fato do poder público ser titular do crédito. Na mesma linha de raciocínio, referido patrimônio restaria lesado (diminuído) pela ausência de contribuição. Com tal afirmação não se pode concordar. É que não há como considerar patrimônio do Poder Público algo que ainda não lhe foi transferido - e, pela dinâmica do crime, nunca lhe será. Antes do efetivo

\footnotetext{
${ }^{108}$ GOMES, Luis Flávio. Da apropriação indébita previdenciária: art. 168-A do Código Penal, com redação dada pela Lei no 9.983 de 14.07.00. Repertório de Jurisprudência IOB, São Paulo, n. 17, p. 366-9, set. 2000.

${ }^{109}$ MACIEL FILHO, Euro Bento. Crimes Previdenciários. São Paulo: Juarez de Oliveira, 2004. p. 85 (sem esses grifos no original).

${ }^{110}$ MACIEL FILHO, Euro Bento. Crimes Previdenciários. São Paulo: Juarez de Oliveira, 2004. p. 111 (sem esses grifos no original).
} 
recolhimento do valor da contribuição ou de qualquer outro tributo o poder público não é titular desse valor.

Com o advento do fato gerador, nasce a obrigação tributária. Veja-se artigo 113 do Código Tributário Nacional:

Art. 113. A obrigação tributária é principal ou acessória.

$\S 1^{\circ}$ A obrigação principal surge com a ocorrência do fato gerador, tem por objeto o pagamento de tributo ou penalidade pecuniária e extingue-se juntamente com o crédito dela decorrente.

(...)

A simples existência de obrigação tributária não permite concluir que os valores a serem recolhidos integram, antes da transmissão (tradição), o patrimônio do poder público, já que esse tem apenas a expectativa de ter entre seus ativos o valor da contribuição. Prescreve o Código Civil, quando cuida de regular a aquisição dos bens móveis que a propriedade das coisas não se transfere pelos negócios jurídicos antes da tradição ${ }^{111}$, e também que os direitos reais sobre coisas móveis, quando constituídos, ou transmitidos por atos entre vivos, só se adquirem com a tradição ${ }^{112}$. Carlos Roberto Gonçalves aduz que o domínio, porém, só se adquire pela tradição, se for coisa móvel (art. 1.226), e pelo registro do título, se for imóvel (art. 1.227) ${ }^{113}$.

Faz-se claro, assim, que não há como considerar o patrimônio como bem jurídico dos crimes contra a seguridade social ${ }^{114}$, seja o patrimônio da União ou da autarquia federal Instituto Nacional do Seguro Social (INSS).

Analisando a inserção, no Código Penal, do crime de apropriação indébita previdenciária entre os crimes contra o patrimônio e o de sonegação de contribuição previdenciária entre os crimes contra a Administração Pública, Heloísa Estellita

\footnotetext{
${ }^{111}$ Código Civil, artigo 1.267.

${ }^{112}$ Código Civil, artigo 1.226. Do mesmo modo regulava o artigo 675 do Código Civil de 1916.

${ }^{113}$ GONÇALVES, Carlos Roberto. Direito das Coisas. v. 3. 5. ed. São Paulo: Saraiva, 2002. p. 83.

114 Em sentido contrário: (...) Ao reprimir penalmente a sonegação de contribuição previdenciária, o legislador, objetivando assegurar o cumprimento das prestações públicas por parte do Estado, especificamente na área previdenciária, protege o patrimônio do ente público, dotado de capacidade ativa para arrecadar tal contribuição, já que quando esse direito é frustrado pela sonegação perpetrada pelo agente há um dano ao patrimônio daquele (PRADO, Luiz Régis. Curso de Direito Penal Brasileiro. v. 4. 4. ed. São Paulo: RT, 2006. p. 538). Confira-se, também: DELMANTO, Celso et al. Código Penal Comentado. 6. ed. Rio de Janeiro: Renovar, 2002. p. 386. p. 689.
} 
Salomão ${ }^{115}$ adverte que teria havido um "polvilhar" de delitos, distribuindo-se-lhes quase que aleatoriamente pela Parte Especial do Código Penal:

uma outra consequiência desse "polvilhar" pode ser a de conduzir o intérprete à conclusão de mudança do bem jurídico tutelado. Assim, poder-se-ia pensar que o art. 168-A do Código Penal está a tutelar o Patrimônio Público e o art. 337-A, a Administração Pública.

Pelo mesmo motivo já invocado - a impossibilidade de considerar patrimônio do órgão público quantia que não lhe foi entregue - contesta-se a opinião de Gilciane Allen Baretta $^{116}$, ao afirmar, com esteio em Rodrigo Sánchez Rios, que

\begin{abstract}
a repressão penal à sonegação de contribuição previdenciária tem como escopo primordial assegurar o cumprimento das prestações públicas por parte do Estado, especificamente na área previdenciária. Protege-se o patrimônio do ente público, dotado de capacidade ativa para arrecadar tal contribuição, já que quando esse direito é frustrado pela sonegação perpetrada pelo agente ocorre um dano àquele patrimônio. Vale dizer: o patrimônio da autarquia é o bem jurídico imediato e o financiamento da Seguridade Social é o bem jurídico mediato (sem destaque no original).
\end{abstract}

Considerando-se que o patrimônio não é bem jurídico tutelado pelas normas que dispõe acerca dos crimes contra a seguridade social, fica afastada, do mesmo modo, a querela acerca de qual patrimônio público seria o lesado. Incabível, assim, a discussão proposta por José Paulo Baltazar Junior ${ }^{117}$, referindo-se ao revogado artigo 95, “d”, da Lei

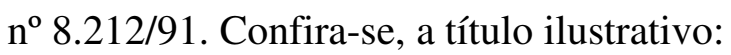

\begin{abstract}
sujeito passivo é o Instituto Nacional do Seguro Social - INSS autarquia federal encarregada da arrecadação, lançamento e normatização das contribuições dos trabalhadores (Lei $\mathrm{n}^{\circ}$ 8.212/91, art. 33). Como autarquia tem personalidade jurídica própria ( $\mathrm{DL} \mathrm{n}^{\circ} 200 / 67$, art. $4^{\circ}$, II, a), é induvidoso que pode ser vítima do crime. Com a devida vênia, não merece acolhida a assertiva de Juary C. Silva no sentido de que "sujeito passivo do crime é a União Federal, não o INSS, autarquia que meramente arrecada as contribuições, como longa manus da União, que as institui”.
\end{abstract}

Resta afastada, portanto, a hipótese de se considerar o patrimônio público como bem jurídico protegido pelos crimes em análise.

${ }^{115}$ SALOMÃO, Heloisa Estellita. Novos Crimes Previdenciários - Lei no 9.983/00, de 14 de julho de 2000: Primeiras Impressões. Revista Dialética do Direito Tributário. São Paulo, n. 64, p. 70-90, jan. 2001.

116 BARETTA, Gilciane Allen. Os crimes fiscais e previdenciários. A extinção da punibilidade. Belo Horizonte: Mandamentos, 2004. p. 96.

117 BALTAZAR JUNIOR, José Paulo. O crime de omissão no recolhimento de contribuições sociais arrecadadas. Porto Alegre: Livraria do Advogado, 2000. p. 104-5. 
3.1.2.2 O patrimônio dos contribuintes-trabalhadores como bem jurídico

Assegura Antonio Lopes Monteiro ${ }^{118}$, ao discorrer sobre o bem jurídico tutelado pelo crime de apropriação indébita previdenciária:

o art. 168-A encontra-se no Título II da Parte Especial do Código Penal - "Dos Crimes Contra o Patrimônio". Na verdade esse novo artigo protege o patrimônio não de uma pessoa ou de algumas pessoas, como nos demais crimes previstos nesse Título, mas o patrimônio de todos os cidadãos que fazem parte do sistema previdenciário. Ademais, embora se fale em crime contra a Previdência Social, no fundo é a Seguridade Social tal como descrita no art. 194 da Constituição da República que está sendo tutelada. E, especialmente, as contribuições sociais, embora tenham sua natureza tributária discutida, não podem ser excluídas, sem mais, do sistema tributário como um todo, até porque a elas se aplicam as normas gerais da legislação tributária (art. 149 e 146, III, da $\mathrm{CF}$ ). Assim, a ordem tributária também faz parte da objetividade jurídica desse tipo penal.

Cabe aqui uma pequena digressão, a fim de se enfrentar adequadamente a proposição de ser o patrimônio do trabalhador-segurado bem jurídico dos crimes contra a seguridade social. O sistema de custeio da seguridade social, de acordo com o artigo 195 da Constituição da República é múltiplo, ou seja, seus recursos afluem de diversas origens. Eis o texto constitucional:

Art. 195. A seguridade social será financiada por toda a sociedade, de forma direta e indireta, nos termos da lei, mediante recursos provenientes dos orçamentos da União, dos Estados, do Distrito Federal e dos Municípios, e das seguintes contribuições sociais:

I - do empregador, da empresa e da entidade a ela equiparada na forma da lei, incidentes sobre:

a) a folha de salários e demais rendimentos do trabalho pagos ou creditados, a qualquer título, à pessoa física que lhe preste serviço, mesmo sem vínculo empregatício;

b) a receita ou o faturamento;

c) o lucro;

II - do trabalhador e dos demais segurados da previdência social, não incidindo contribuição sobre aposentadoria e pensão concedidas pelo regime geral de previdência social de que trata o art. 201;

III - sobre a receita de concursos de prognósticos.

IV - do importador de bens ou serviços do exterior, ou de quem a lei a ele equiparar.

O trabalhador, tenha ou não vínculo empregatício, nos termos do inciso II supratranscrito, deve contribuir com o sistema de custeio da previdência, já que recebe

${ }^{118}$ MONTEIRO, Antonio Lopes. Crimes contra a Previdência Social. 2. ed. São Paulo: Saraiva, 2003. p. 31. 
rendimentos dos quais já foi diminuída, pelo empregador, parcela que posteriormente será recolhida aos cofres públicos. Vale citar desde já, apesar da questão vir a ser enfrentada mais adiante ${ }^{119}$, que o desconto seguido da ausência de recolhimento é que configura o crime de apropriação indébita previdenciária (Código Penal, artigo 168-A).

Portanto, o trabalhador ativo tem apartada de seus rendimentos certa quantidade da riqueza que iria auferir para, assim, custear o sistema de seguridade. Isso ocorre durante toda a vida ativa de trabalho, todo mês. Posteriormente, quando, por exemplo, o trabalhador preenche os requisitos legais e se aposenta, recebe assistência financeira. Verifica-se, assim, que em dois momentos se pode relacionar o patrimônio do trabalhador ao sistema previdenciário: os valores que são por ele carreados ao sistema (pagos) e os valores que, num momento futuro, ser-lhe-ão entregues a título, por exemplo, de aposentadoria (recebidos).

Ao se falar em patrimônio do trabalhador como bem jurídico do crime de apropriação indébita previdenciária ${ }^{120}$, é preciso delimitar para qual das duas situações se aponta: o patrimônio não auferido - pois descontado - para pagar suas obrigações previdenciárias ou o percebido quando recebe assistência do sistema? Qual dos dois seria o bem jurídico tutelado pelo crime de apropriação indébita previdenciária? Nenhum deles.

Não se pode considerar o patrimônio descontado pelo empregador e não repassado aos cofres públicos como o bem jurídico protegido pelo artigo 168-A do Código Penal. É que o trabalhador não faz jus a essa quantia. De fato, mediante a contraprestação do trabalho, merece o empregado a remuneração acordada com o empregador. Entretanto, determina a legislação previdenciária que, do salário, deve ser descontada parcela para recolhimento aos cofres previdenciários. Assim, muito embora o trabalhador tenha gerado a riqueza que seu empregador irá recolher, tal parcela não pode ser por ele usufruída, já que há a determinação legal da subtração.

Também não parece correto tomar como bem jurídico da norma em questão os valores patrimoniais a serem auferidos pelo trabalhador quando, por exemplo, do advento de sua aposentadoria. É que o fato do empresário ou empregador individual cometer as

\footnotetext{
${ }^{119}$ Capítulo 3.2.1.3.

${ }^{120}$ A questão se coloca, apenas, em relação ao crime de apropriação indébita previdenciária, pois no que diz respeito ao crime de sonegação de contribuição previdenciária o trabalhador não tem qualquer relação com a descrição típica, ou seja, as quantias passíveis de serem sonegadas não são dele descontadas.
} 
condutas típicas dos artigos 168-A ou 337-A do Código Penal em nada prejudica os trabalhadores vinculados a essas fontes de custeio

Ainda que não se recolha a quantia descontada do empregado - o que em tese configura o crime de apropriação indébita previdenciária - ou que não se recolha a parcela referente à contribuição da própria empresa - conduta típica da sonegação de contribuição previdenciária - isso não influencia o cálculo atuarial de concessão do benefício. Confirase o artigo 34 da Lei $n^{\circ} 8.213 / 91^{121}$ :

\begin{abstract}
Art. 34. No cálculo do valor da renda mensal do benefício, inclusive o decorrente de acidente do trabalho, serão computados:

I - para o segurado empregado e trabalhador avulso, os salários-de-contribuição referentes aos meses de contribuições devidas, ainda que não recolhidas pela empresa, sem prejuízo da respectiva cobrança e da aplicação das penalidades cabíveis;

Fica evidente, assim, que a apropriação indébita previdenciária não traz qualquer tipo de lesão ao empregado-contribuinte. Não pode, pois, seu patrimônio ser considerado bem jurídico dos crimes previdenciários ${ }^{122}$. É o que se conclui pela análise sistemática da legislação da seguridade social.

3.1.2.3 A livre concorrência das empresas como bem jurídico

Mesmo com menor intensidade, ocasionalmente é citada a livre concorrência das empresas como bem jurídico a ser protegido pelos crimes previdenciários. Nessa vertente:

\footnotetext{
${ }^{121}$ Disponível em <http://www.planalto.gov.br/ccivil_03/Leis/L8213cons.htm>, acesso em 10.ago.2007, sem destaque no original.

${ }^{122} O$ empregado e o avulso não são vítimas do delito, pois a omissão no recolhimento por parte do empregador ou tomador de serviços não lhes acarreta prejuízo direto, uma vez que o art. 34 da Lei dos Beneficios da Previdência Social prevê que sejam computados no cálculo dos benefícios "para o segurado empregado e trabalhador avulso, os salários-de-contribuição referentes aos meses de contribuições devidas, ainda que não recolhidas pela empresa, sem prejuízo da respectiva cobrança e da aplicação das penalidades cabiveis" (BALTAZAR JUNIOR, José Paulo. O crime de omissão no recolhimento de contribuições sociais arrecadadas. Porto Alegre: Livraria do Advogado, 2000. p. 104-5).
} 
(...) $\mathrm{O}$ delito de apropriação indébita previdenciária sempre ocasiona, em conseqüência, um dano patrimonial, que acaba afetando também e secundariamente os próprios segurados e a livre concorrência das empresas ${ }^{123}$.

Crê-se que, ao afirmar que o crime de apropriação indébita previdenciária tem como bem jurídico a livre concorrência das empresas, o autor tenha concluído que o não recolhimento dos valores devidos possibilite uma vantagem competitiva em relação às demais empresas. Assim, determinada empresa que não cumpre com suas obrigações fiscais estaria auferindo benefícios e restaria prejudicada a situação de igualdade que deve reinar em cada um dos mercados.

A supressão dos pagamentos previdenciários propiciaria um excedente monetário, que poderia ser carreado para reinvestimento ou, simplesmente, a empresa teria condições de estabelecer um preço menor para os produtos ou serviços que oferta no mercado. Restaria lesada a norma programática do inciso IV do artigo 170 da Constituição da República, já que a livre concorrência foi eleita como um dos princípios da ordem econômica nacional. Confira-se o texto constitucional:

Art. 170. A ordem econômica, fundada na valorização do trabalho humano e na livre iniciativa, tem por fim assegurar a todos existência digna, conforme os ditames da justiça social, observados os seguintes princípios:

(...)

IV - livre concorrência;

(...)

Com tal afirmação não se pode concordar. A livre concorrência, embora seja bem jurídico protegido por normas penais, não o é pelas normas que criminalizam as condutas de apropriação indébita previdenciária (Código Penal, artigo 168-A) e de sonegação de contribuição previdenciária (Código Penal, artigo 337-A).

Os crimes de concorrência desleal, primitivamente descritos no artigo 196 do Código Penal, hoje são tipificados na Lei $\mathrm{n}^{\circ}$ 9.279, de 14 de maio de 1996. Por sua vez, a Lei $n^{\circ} 8.137$ de 27 de dezembro de 1990 define, em seus artigos $4^{\circ}, 5^{\circ}$ e $6^{\circ}$, delitos contra a ordem econômica, que também são conhecidos por crimes concorrenciais, tal qual o ajuste de empresas para o domínio de mercado por abuso do poder econômico, por exemplo. Esses são os diplomas legais que tutelam a livre concorrência. Os tipos delituosos descritos

${ }^{123}$ GOMES, Luis Flávio. Da apropriação indébita previdenciária: art. 168-A do Código Penal, com redação dada pela Lei no 9.983 de 14.07.00. Repertório de Jurisprudência IOB, São Paulo, n. 17, p. 366-9, set. 2000. (sem destaque no original). 
nessas leis em nada se assemelham aos da apropriação indébita previdenciária ou sonegação de contribuição previdenciária, e com eles não guardam nenhuma relação.

Importante realizar breve digressão, a fim de demonstrar ser incabível considerar os tipos penais introduzidos no Código Penal pela Lei $n^{\circ}$ 9.983/00 como protetores da livre concorrência. Faz-se relevante aludir ao conceito de bens jurídicos concêntricos. Tome-se como exemplo a vida, bem jurídico que se poderia chamar de originário em face da integridade física ou do risco nos crimes de periclitação. Não resta dúvida que a tutela da integridade física tem dignidade penal, mas também parece ser inconteste que a proteção oferecida à integridade física é de caráter secundário ou de subsidiária ordem, pois a conduta lesiva à integridade física é, ainda que em momento primitivo, uma ofensa à vida - mesmo ínfima.

Apenas para demonstrar que esse raciocínio alcança outras condutas e outros graus de subsidiariedade, basta argumentar com os crimes de perigo, como, por exemplo, o porte ilegal de arma ou o dirigir embriagado: estes últimos são subsidiários em relação à lesão corporal, que por sua vez é subsidiária em relação ao homicídio. Essa inevitável correlação existe porque ambos os tipos penais, tanto o do homicídio quanto o da lesão corporal, têm um núcleo originário único, qual seja, a vida. Portanto, sob pena de se identificar todo e qualquer comportamento indesejável como uma potencial lesão à vida, não parece ser adequado regredir-se indefinidamente a fim de buscar bens jurídicos secundários ou bens jurídicos mediatos.

Com efeito, poder-se-ia defender o seguinte raciocínio: o não recolhimento das contribuições previdenciárias afeta a livre concorrência das empresas. Afetada a concorrência, alguma empresa poderia se sobrepujar às demais, utilizando-se da vantagem competitiva gerada pelo excedente monetário que não seria recolhido aos cofres públicos. Com a vantagem concorrencial conquistada, as outras empresas do ramo poderiam ser levadas à bancarrota, e a empresa beneficiada pelo não recolhimento passaria a exercer monopólio dentro daquele mercado. No momento seguinte, senhora do mercado, os preços cobrados pelos produtos comercializados ou pelos serviços prestados poderiam sofrer aumentos ilimitados, já que não mais existiria a regulação natural que o mercado dá à precificação. Assim, com preços artificialmente elevados, os consumidores deixariam de usufruir dos produtos-serviços oferecidos pela empresa, o que, no extremo, pode significar 
risco à vida, caso se tratem, por exemplo, de produtos médicos ou de gêneros alimentícios de grande necessidade.

Do mesmo modo, e a prevalecer esse tortuoso raciocínio, um crime de licitação, previsto na Lei $n^{\circ} 8.666$ de 21 de junho de 1993, poderia ser considerado um crime contra a vida, já que os valores criminosamente desviados poderiam ter sido investidos em políticas públicas de saneamento básico, evitando doenças e mortes, ou ainda na recuperação de estradas, evitando acidentes automobilísticos.

Portanto, esse retorno ao infinito não parece ser adequado a fim de se estabelecer o bem jurídico tutelado por qualquer norma penal, mesmo porque é função do bem jurídico preencher de conteúdo a conduta proibida. Com esse infinito regresso o bem jurídico perde objetividade, e deixa de cumprir sua função, que é delimitar o âmbito de proibição da norma. De fato, admitir-se vários graus de subsidiariedade, neste caso, torna o bem jurídico por demais fluido, frustrando sua natureza e retirando-lhe utilidade.

Cite-se, ainda, que apontar a livre concorrência como bem jurídico tutelado pelas normas dos artigos 168-A e 337-A do Código Penal pressupõe que o valor não recolhido aos cofres públicos, obrigatoriamente, seja investido na empresa, a fim de garantir vantagem competitiva sobre os demais atores do mesmo mercado. E se o empresário, verbi gratia, apropria-se desse valor, em benefício próprio? Qual ganho competitivo seria gerado em benefício da empresa? Obviamente nenhum.

Não há que se considerar, pois, a livre concorrência como bem jurídico tutelado pelos crimes previdenciários.

3.1.2.4 A regular escrituração contábil como bem jurídico

Há quem afirme ${ }^{124}$, com relação ao crime de sonegação de contribuição previdenciária:

estamos diante de um crime também previsto na Parte Especial do Código, no Título XI, Capítulo II. "Dos Crimes Praticados por Particular contra a Administração em Geral". Assim a objetividade jurídica é o seu bom funcionamento: é a regular escrituração contábil no que se refere aos dados exigidos pela Previdência Social.

\footnotetext{
${ }^{124}$ MONTEIRO, Antonio Lopes. Crimes contra a Previdência Social. 2. ed. São Paulo: Saraiva, 2003. p. 59.
} 
Tal afirmação, ao que parece, não se coaduna com a melhor interpretação que se pode extrair a respeito da descrição típica da conduta. É que, igualmente à clássica sonegação fiscal, do artigo $1^{\circ}$ da Lei ${ }^{\circ}$ 8.137/90, o crime de sonegação de contribuição previdenciária, para que se consume, exige mais do que a mera incorreção da escrituração contábil. Na verdade, a incorreta escrituração contábil - um falso - é meio pelo qual o autor atingirá seu desiderato, qual seja, o não recolhimento dos valores devidos.

O fim do agente não é fraudar a escrituração contábil, assim como o fim da norma criminalizadora do artigo 337-A do Código Penal não é garantir uma incólume escrita contábil.

Ambos, sujeito ativo e passivo, têm os olhos voltados para a arrecadação da contribuição. Quem desfere disparo de arma de fogo em direção a outrem não tem sua intencionalidade voltada para o disparo em si, mas para as conseqüências que tal disparo irá ocasionar, assim como quem frauda a escrita contábil não quer meramente transcrever para o papel uma situação diferente da real, mas pretende se locupletar com esse fato, diminuindo ou suprimindo a arrecadação previdenciária.

Não se pode considerar, assim, ser a escrita contábil o bem jurídico protegido pela norma do artigo 337-A do Código Penal.

3.1.2.5 Conclusão parcial: a arrecadação para a seguridade social como bem jurídico

O bem jurídico tutelado pelas normas dos artigos 168-A e 337-A do Código Penal é a arrecadação para a seguridade social. Nesse sentido,

\footnotetext{
o bem jurídico protegido pelo art. 337-A não é o patrimônio da Seguridade Social, mas os interesses estatais ligados à arrecadação das contribuições previdenciárias e seus acessórios, devidos à Previdência Social (INSS) e não ao conjunto integrado de ações que compõem a Seguridade Social, visando à boa execução das políticas sociais e do custeio e manutenção do sistema de aposentadorias, auxílios em geral e outros benefícios. Protege, principalmente, a Administração Pública ${ }^{125}$.
}

\footnotetext{
125 Rui Stoco, citado em MACIEL FILHO, Euro Bento. Crimes Previdenciários. São Paulo: Juarez de Oliveira, 2004. p. 113 (sem grifos no original). Não se pode concordar com o autor citado, entretanto, quando esse afirma que o crime protege, principalmente, a Administração Pública, pelo mesmo motivo já exposto, qual seja, o retorno ao infinito que ocasiona a perda de concretude do bem jurídico e, por conseguinte, da delimitação do âmbito de proteção da norma.
} 
Ao criminalizar as condutas de apropriação indébita previdenciária e sonegação de contribuição previdenciária as normas penais objetivam, incontestavelmente, evitar condutas que esvaziariam o afluxo de receita ao sistema. A arrecadação, portanto.

Não se pode admitir como adequada a afirmação de que o bem jurídico protegido pelos crimes em questão é a seguridade social. Trata-se de conclusão ampla demais.

Muito embora a arrecadação de contribuições previdenciárias seja de interesse da seguridade social, também a ela interessam muitas outras condutas. Nesse diapasão, deve ficar esclarecido que inúmeras ações afetam a seguridade social. Por exemplo, a concessão de um benefício mediante a utilização de documentos falsificados. Por exemplo, a continuidade do recebimento de aposentadoria pelos parentes, mediante falta de comunicação do falecimento do beneficiário. Por exemplo, o roubo de um carro forte que transportava cartões magnéticos que seriam distribuídos aos segurados, a fim de que esses pudessem efetivar o saque mensal dos benefícios.

Ou seja: defender que as condutas dos artigos 168-A e 337-A do Código Penal têm como bem jurídico a seguridade social não está equivocado, mas também é afirmação que peca por não delimitar, com a precisão técnica que se espera do jurista, o restrito âmbito de incidência da norma.

O que se tutela, portanto, com as normas em questão, é a arrecadação previdenciária. Admite-se como correta, embora ainda peque pela precisão, a afirmação de Heloisa Estellita Salomão:

assim, temos, agora, verdadeiros crimes contra a arrecadação tributária inseridos dentro do Título II, dedicado aos "crimes contra o patrimônio", é o caso do novel art. 168-A, e no seio do Título XI, dedicado aos "crimes contra a administração pública”, sendo o caso do art. 337-A (...) Entendemos, assim, que, apesar da defeituosa e censurável localização topográfica dos novos "crimes contra a previdência social" descritos nos artigos 168-A e 337-A no seio da Parte Especial do Código Penal, o bem jurídico tutelado é o mesmo que já o era pela Lei $n^{\circ} 8.212 / 91$, ou seja a arrecadação tributária ${ }^{126}$.

Diz-se pecar a autora quanto à precisão, pois, se é certo que todo o delito contra a arrecadação previdenciária pode ser considerado um delito conta a arrecadação

\footnotetext{
${ }^{126}$ SALOMÃO, Heloisa Estellita. Novos Crimes Previdenciários - Lei no 9.983/00, de 14 de julho de 2000: Primeiras Impressões. Revista Dialética do Direito Tributário. São Paulo, n. 64, p. 70-90, jan. 2001.
} 
tributária, a recíproca não se aplica ${ }^{127}$. Portanto, os crimes de sonegação fiscal do artigo $1^{\circ}$ da Lei no 8.137/90 também são crimes contra a arrecadação tributária, apesar de distintos dos crimes dos artigos 168-A e 337-A do Código Penal.

Com correção, leciona Cezar Roberto Bitencourt, acerca, respectivamente, dos crimes de apropriação indébita previdenciária e sonegação de contribuição previdenciária:

\begin{abstract}
bem jurídico protegido são as fontes de custeio da seguridade social, particularmente os direitos relativos à saúde, à previdência e à assistência social (art. 194 da CF). São protegidas especialmente contra a apropriação indébita que pode ser praticada por quem tem o dever de recolher os tributos e taxas. É, em outros termos, a tutela da subsistência financeira da previdência social ${ }^{128}$.

bem jurídico protegido são as fontes de custeio da seguridade social, particularmente os direitos relativos à saúde, à previdência e à assistência social (art. 194 da CF) ou sinteticamente, a seguridade social ${ }^{129}$.
\end{abstract}

Em sentido muito próximo aduz Wagner Balera:

o objeto jurídico tutelado será, conforme este entendimento, o equilíbrio econômico financeiro do sistema de seguridade social que será abalado pela ausência de recolhimento, na época própria, das contribuições sociais, em prejuízo de toda a sociedade ${ }^{130}$.

A corroborar o quanto afirmado - ser a arrecadação para a seguridade social bem jurídico dos delitos em estudo - basta que se atenha às inúmeras prescrições legais que tratam da extinção da punibilidade pelo pagamento dos valores devidos.

O raciocínio é linear: efetivado o pagamento da quantia apropriada ou sonegada, a arrecadação resta intocada, pois se recompõe a inicial expectativa de receita do órgão público (arrecadação). Por benesse legal, de questionável virtude, fica, assim, extinta a punibilidade do autor do fato ${ }^{131}$.

Conclui-se, ser a arrecadação para a seguridade social o bem jurídico tutelado pela norma dos artigos 168-A e 337-A do Código Penal.

\footnotetext{
${ }^{127}$ Conferir capítulo 2.3, que conclui pela natureza tributária da contribuição previdenciária.

${ }^{128}$ BITENCOURT, Cesar Roberto. Tratado de Direito Penal - Parte Especial. v. 3. São Paulo: Saraiva, 2003. p. 254.

129 BITENCOURT, Cesar Roberto. Tratado de Direito Penal - Parte Especial. v. 4. São Paulo: Saraiva, 2004. p. 499.

${ }^{130}$ BALERA, Wagner. Crime Tributário de Apropriação Indébita. Repertório de Jurisprudência IOB, São Paulo, n. 4, p. 83-6, fev. 1998.

${ }^{131}$ A esse respeito confira-se capítulo 5.
} 
3.2 A prescrição normativa da Lei $n^{\circ}$ 9.983/00: os tipos incriminadores

3.2.1 Apropriação indébita previdenciária (CP, art. 168-A)

3.2.1.1 Histórico legislativo

É de 1937 o primeiro texto normativo que define como crime a conduta de apropriação indébita previdenciária $^{132}$ :

Art. $5^{\circ}$. O empregador que retiver as contribuições recolhidas de seus empregados e não as recolher na época própria incorrerá nas penas do art. $331, \mathrm{n}^{\circ}$ 2, da Consolidação das Leis Penais, sem prejuízo das demais sanções estabelecidas neste decreto-lei.

Posteriormente, a conduta passou a ser incriminada pela Lei Orgânica da Previdência Social (LOPS), Lei no 3.807 de 26 de agosto de 1960. Referido texto legal equiparava a conduta lesiva à previdência à apropriação indébita, nos seguintes termos:

Art. 86. Será punida com as penas do crime de apropriação indébita a falta de recolhimento, na época própria, das contribuições e de outras quaisquer importâncias devidas às instituições de previdência e arrecadadas dos segurados ou do público.

Parágrafo Único. Para os fins deste artigo, consideram-se pessoalmente responsáveis o titular da firma individual, os sócios solidários, gerentes, diretores ou administradores das empresas incluídas no regime desta lei.

Poucos anos mais tarde, o Decreto-Lei nº 66, de 21 de novembro de 1966 veio incriminar outros fatos relacionados à contribuição previdenciária ${ }^{133}$.

Já em 1976, pelo Decreto 77.077, de 24 de janeiro, expediu-se a Consolidação das Leis da Previdência Social (CLPS), que trouxe, em seu artigo 149, redação quase que exatamente igual à da Lei Orgânica da Previdência Social (LOPS), de 1960:

\footnotetext{
${ }^{132}$ Decreto-Lei no 65, de 14 de dezembro de 1937 que dispõe sobre o recolhimento das contribuições devidas por empregadores e empregados aos Institutos e Caixas de Aposentadorias e Pensões.

${ }^{133}$ Referido diploma legal equiparou algumas condutas lesivas à previdência social a figuras típicas já descritas pelo Código Penal. A título de exemplo, o Decreto-Lei passou a considerar crime de falsidade ideológica, definido no artigo 299 do Código Penal, inserir ou fazer inserir nas folhas de pagamento, a que se refere o item I do art. 80, pessoas que não possuem efetivamente a condição de segurado, ou inserir ou fazer inserir (...) na carteira profissional do empregado, declaração falsa ou diversa da que deveria ser escrita (CASTILHO, Ela Wiecko Volkner de. Crimes contra a previdência social. Revista da ProcuradoriaGeral da República. n. 8, p. 127-37, jan./jun. 1996).
} 
Art. 149. A falta de recolhimento, na época própria, de contribuição ou outra importância devida ao INPS e arrecadada dos segurados ou do público será punida com as penas do crime de apropriação indébita.

O Decreto $\mathrm{n}^{\circ}$ 83.081, de 24 de janeiro de 1979, em seu artigo 167, que aprovou o Regulamento do Custeio da Previdência Social estabeleceu constituir crime de apropriação indébita, nos termos da legislação penal, deixar de recolher na época própria, contribuição ou outra quantia arrecadada do segurado ou do público e devida à previdência social $^{134}$. Promulgado aos 23 de janeiro de 1984, em nova Consolidação das Leis da Previdência Social (CLPS), o Decreto $n^{\circ}$ 89.321/84 repetiu a redação do revogado Decreto ${ }^{\circ}$ 77.077/76, substituindo, apenas, a expressão INPS por Previdência Social.

Em 1990, através da Lei $n^{\circ} 8.137$ de 27 de dezembro, definiram-se, entre outros, os crimes contra a ordem tributária, dentre eles a falta de recolhimentos à previdência social. Com referido diploma legal, e já sob a égide da Constituição da República de 1988, a apropriação indébita previdenciária deixa de ser equiparada à apropriação indébita, como vinha acontecendo desde a criminalização da conduta, mas passa a ser tratada como sendo da mesma natureza dos crimes contra a ordem tributária. Ainda assim não adquire autonomia:

Art. $2^{\circ}$ Constitui crime da mesma natureza:

(...)

II - deixar de recolher, no prazo legal, valor de tributo ou de contribuição social, descontado ou cobrado, na qualidade de sujeito passivo de obrigação e que deveria recolher aos cofres públicos;

Já em 24 de julho de 1991, cerca de seis meses após a promulgação da Lei no $8.137 / 90$, teve vigência a Lei $n^{\circ} 8.212 / 91^{135}$ que, pela primeira vez, criou para a apropriação indébita figura incriminadora autônoma:

Art. 95. Constitui crime:

(...)

d) deixar de recolher, na época própria, contribuição ou outra importância devida à Seguridade Social e arrecadada dos segurados ou do público.

Muito embora houvesse o legislador cuidado de construir redação própria para o crime de apropriação indébita previdenciária, continuou-se, com relação à pena, a fazer

${ }^{134}$ DIAS, Jefferson Aparecido. Crime de Apropriação Indébita Previdenciária. CP, art. 168-A, § $1^{\circ}$, inc. I. 2. ed. Curitiba: Juruá, 2007. p. 40.

${ }^{135}$ Entre outras providências, normatizou a organização da seguridade social e instituiu seu plano de custeio. 
remissão a outro dispositivo legal. Com efeito, o $\S 1^{\circ}$ do artigo 95 da Lei $n^{\circ} 8.212 / 91$, determinou fosse aplicada ao crime em questão a pena do artigo $5^{\circ}$ da Lei $n^{\circ} 7.492 / 86^{136}$, que pune com pena de reclusão de 2 (dois) a 6 (seis) anos, e multa, a apropriação indébita do controlador ou administrador de instituição financeira.

A redação de dispositivo de lei específico para descrever e criminalizar a conduta da apropriação indébita previdenciária colocou fim a intensa discussão doutrinária. É que inúmeros autores entendem pela inviabilidade de criminalização por equiparação à clássica apropriação indébita. Cite-se, em primeiro lugar, que a tradicional apropriação indébita é crime contra o patrimônio, e a apropriação indébita previdenciária tem distinto bem jurídico ${ }^{137}$.

Mas não é só. A dessemelhança das condutas afasta a tipicidade da apropriação indébita previdenciária da clássica apropriação. O raciocínio é o seguinte. Figure-se situação hipotética, em que determinada empresa possui em seu caixa quantia suficiente para honrar com a folha de pagamento dos empregados, considerados os valores dos salários "cheios”, sem qualquer desconto.

No dia estipulado para o pagamento, e após os cálculos aritméticos das deduções, os valores referentes aos salários líquidos são entregues aos empregados a título de salário, permanecendo em poder da empresa, por óbvio, todo o dinheiro que não foi gasto com a folha de pagamentos. Em momento subsequiente, determinado pela legislação previdenciária, nasce outra obrigação para o empregador: recolher determinada quantia a título de contribuição previdenciária. O não recolhimento de tal quantia não pode ser tido como apropriação indébita, pois o proprietário não pode ser sujeito ativo de apropriação que tem por objeto material dinheiro de que já era, e sempre foi, $\operatorname{titular}^{138}$.

\footnotetext{
${ }^{136}$ Cabe ressaltar que, originalmente, a remissão ao artigo $5^{\circ}$ da Lei $n^{\circ} 7.492 / 86$ era feita pelo art. 105 do Decreto $n^{\circ} 612 / 92$, o que trazia flagrante inconstitucionalidade ao dispositivo.

${ }^{137}$ Conferir capítulo 3.1.2.5.

${ }^{138}$ Nesse sentido, em parecer publicado pela Revista dos Tribunais acerca da taxa para o financiamento dos produtores e da contribuição assistencial é o entendimento de Miguel Reale Júnior, que se transcreve parcialmente: (...) o crime de não-recolhimento de tributos apenas se realiza tipicamente se prevista figura típica específica na lei. Há necessidade, destarte, de redação típica precisa e taxativa da conduta de nãorecolhimento de impostos, muito embora essa figura típica tenha tomado, no passado, de empréstimo da apropriação indébita, a pena - mas só a pena! (REALE JÚNIOR, Miguel. Não há apropriação indébita por equiparação. Revista dos Tribunais. São Paulo, v. 87, n. 752, p. 467-77, jun. 1998).
} 
Na verdade, o empregador tem duas obrigações a cumprir, o pagamento da folha dos empregados (já com descontos) e o recolhimento de determinada quantia ao órgão arrecadador das contribuições previdenciárias. O caixa que fará frente a essa duas obrigações é único, sendo que os valores são pertencentes ao empregador. Não há, assim, como considerar o descumprimento da segunda obrigação - com a Previdência - como apropriação indébita, já que no mundo real, dos fatos, essa quantia nunca esteve na posse dos empregados. E, obviamente, não existe apropriação indébita que tenha como objeto material dinheiro próprio, porque no mundo real a empresa sempre foi titular de tal quantia.

A Lei $n^{\circ}$ 9.983/00 revogou expressamente, por seu artigo $3^{\circ}$, a alínea "d" do artigo 95 da Lei $n^{\circ} 8.212 / 91$, e introduziu no Código Penal, sob a numeração $168-\mathrm{A}^{139}$, o crime de apropriação indébita previdenciária.

\subsubsection{Origem do tipo penal}

Inevitável a comparação do tipo penal do artigo 168-A com a descrição da apropriação indébita do artigo 168 do Código Penal que, em nossa legislação, é um desdobramento do furto ${ }^{140}$. Confira-se Nélson Hungria:

no Brasil, o Código de 1830 não reconhecia autonomia ao crime que se trata, dispondo no seu art. 258, que "também cometerá furto... o que tendo para algum fim recebido a coisa alheia por vontade do seu dono se arrogar depois o domínio, ou uso, que lhe não fora transferido".

De idêntico modo normatizou o Código Penal dos Estados Unidos do Brasil, de 1890, que continuava a destacar a apropriação indébita como espécie do furto:

Art. 331. É crime de furto, sujeito ás mesmas penas e guardadas as distincções do artigo precedente

(...)

\footnotetext{
${ }^{139}$ A combinação de número e letra maiúscula para indicar o tipo é exigência da Lei Complementar $n^{\circ} 95$, de 26 de fevereiro de 1998, que dispõe sobre a elaboração, a redação, a alteração e a consolidação das leis, conforme determina o parágrafo único do artigo. 59 da Constituição Federal. Em seu artigo. 12, III, "b", com redação dada pela Lei Complementar no 107/01 prescreve: é vedada, mesmo quando recomendável, qualquer renumeração de artigos e de unidades superiores ao artigo, referidas no inciso $V$ do art. 10, devendo ser utilizado o mesmo número do artigo ou unidade imediatamente anterior, seguido de letras maiúsculas, em ordem alfabética, tantas quantas forem suficientes para identificar os acréscimos.

${ }^{140}$ HUNGRIA, Nélson; FRAGOSO, Heleno Cláudio. Comentários ao Código Penal. v. VII. 4. ed. Rio de Janeiro: Forense, 1980.
} 
$2^{\circ}$ Apropriar-se de cousa alheia, que lhe houver sido confiada, ou consignada por qualquer título, com obrigação de a restituir, ou fazer della uso intederminado ${ }^{141}$.

A Consolidação das Leis Penais, de 1932, manteve a mesma redação e é só no Código Penal de 1940 que a apropriação indébita ganha artigo próprio, adquirindo autonomia frente ao furto.

Portanto, a apropriação indébita previdenciária, se tomada a evolução do tipo penal, representa uma construção de terceira geração, já que deriva da apropriação indébita que, por sua vez, nasce como uma hipótese de furto, que dele se distingue por se referir à legitimidade da posse.

Euro Bento Maciel Filho ${ }^{142}$ aponta três diferenças entre a conduta "clássica" de apropriação indébita e a novel apropriação indébita previdenciária, quais sejam, a figura do artigo 168 descreve conduta comissiva, de apropriação, enquanto a do artigo 168-A enuncia crime de conduta mista, pois sucede à ação comissiva de apropriação conduta omissiva, de não-repasse dos valores descontados ao órgão público arrecadador; a tradicional apropriação é crime material, que exige resultado naturalístico para sua consumação, enquanto a apropriação indébita previdenciária, embora possa produzir resultado, não o exige para sua configuração, o que a caracterizaria como crime formal; por fim, não há que se falar em posse anterior quando se trata da apropriação previdenciária, já que tal posse é mera presunção que se esconde por trás de uma operação aritmética de desconto dos ganhos do empregado, pois, de fato, quando o empregador paga o salário ao empregado não existe o empenho do montante total, mas só da quantia líquida, já realizado o cálculo e diminuída a parcela retida.

3.2.1.3 Conduta punível e análise dogmática

A conduta da apropriação indébita previdenciária está tipificada no artigo 168A do Código Penal, que tem a seguinte redação:

Art. 168-A. Deixar de repassar à previdência social as contribuições recolhidas dos contribuintes, no prazo e forma legal ou convencional:

${ }^{141}$ Grafia original, conforme PIERANGELI, José Henrique. Códigos Penais do Brasil: Evolução histórica. São Paulo: RT, 2005. p. 311.

${ }^{142}$ MACIEL FILHO, Euro Bento. Crimes Previdenciários. São Paulo: Juarez de Oliveira, 2004. p. 83-4. 
Pena - reclusão, de 2 (dois) a 5 (cinco) anos, e multa.

$\S 1^{\circ}$ Nas mesmas penas incorre quem deixar de:

I - recolher, no prazo legal, contribuição ou outra importância destinada à previdência social que tenha sido descontada de pagamento efetuado a segurados, a terceiros ou arrecadada do público;

II - recolher contribuições devidas à previdência social que tenham integrado despesas contábeis ou custos relativos à venda de produtos ou à prestação de serviços;

III - pagar benefício devido a segurado, quando as respectivas cotas ou valores já tiverem sido reembolsados à empresa pela previdência social (...)

Imperioso notar, pois salta aos olhos, que se trata de norma penal em branco ${ }^{143}$. No que diz respeito ao caput há que se definir, para a completa intelecção do tipo, quem são os contribuintes e qual o prazo e forma legal-convencional de contribuição. Faz-se necessário diferenciar os contribuintes dos segurados, pois, apesar de, eventualmente, a figura do contribuinte coincidir com a do segurado, isso não se faz regra, por se tratarem de entes jurídicos distintos ${ }^{144}$.

A doutrina previdenciária aponta como contribuintes as empresas, o empregador doméstico e os trabalhadores, sendo que estes também são segurados. De acordo com a definição legal, contribuinte é quem tenha relação pessoal e direta com a situação que constitua o fato gerador da obrigação ${ }^{145}$.

Segurados são as pessoas físicas que exercem, exerceram ou não atividade, remunerada ou não, efetiva ou eventual, com ou sem vínculo empregatício ${ }^{146}$. A definição é por demais ampla, uma vez que a lei previdenciária admite, até por sua índole, inúmeras possibilidades de benefício. Ainda com relação aos segurados, são divididos em duas espécies, classificação cujo tom advém da modalidade de filiação: obrigatória ou facultativa. Os primeiros são filiados ao sistema previdenciário por imposição legal (verbi

\footnotetext{
${ }^{143}$ São normas de tipo incompleto, normas em que a descrição das circunstâncias elementares do fato tem de ser completada por outra disposição legal, já existente ou futura. Nelas a enunciação do tipo mantém deliberadamente uma lacuna, que outro dispositivo legal virá integrar. Nessas leis existe sempre um comando ou uma proibição, mas enunciados, em geral, de maneira genérica, a que só a disposição integradora dará a configuração específica (BRUNO, Aníbal. Direito Penal, parte geral. t. 1. 3. ed. Rio de Janeiro, 1967. p. 190).

144 CAMARGO DOS SANTOS, Leandro Luis. Curso de Direito da Seguridade Social. São Paulo: LTr, 2005. p. 94.

${ }^{145}$ Código Tributário Nacional, artigo 121, parágrafo único, I.

${ }^{146}$ MARTINS, Sergio Pinto. Direito da Seguridade Social. 9. ed. São Paulo: Atlas, 1998. p. 95.
} 
gratia, os empregados) e os outros têm seu vínculo oriundo de opção, como os desempregados, a dona de casa ou o estudante ${ }^{147}$.

Por determinação legal, muito embora seja considerado contribuinte e segurado, não cabe ao empregado, por si, providenciar o recolhimento da contribuição previdenciária aos cofres públicos. Tal função é legalmente atribuída ao empregador, na maior parte das vezes uma pessoa jurídica, que é denominado responsável. Em termos tributários, responsável é o sujeito passivo da obrigação tributária que não se reveste da condição de contribuinte, mas tem obrigação que decorre de texto de lei ${ }^{148}$. De fato, o artigo 30 da Lei $n^{\circ}$ 8.212/91 imputa ao empregador o ônus de descontar, arrecadar e recolher aos cofres da Seguridade Social a contribuição dos segurados que emprega ${ }^{149}$.

A periodicidade da obrigação é mensal, e o prazo estabelecido para o recolhimento das contribuições descontadas dos empregados é o dia dez do mês seguinte ao da competência. Vale destacar que, neste aspecto, a redação do dispositivo que complementa a norma do caput do artigo 168-A é dada pela Lei $\mathrm{n}^{\circ} 11.488 / 07$, que alterou o prazo de arrecadação ${ }^{150}$.

Preenchidas as lacunas - como já se disse, trata-se de norma penal em branco insta destacar que a conduta típica do dispositivo em questão é exclusivamente a dolosa, por força do parágrafo único do artigo 18 do Código Penal ${ }^{151}$. Assim, não configura crime a conduta do sujeito que, por imprudência, imperícia ou negligência deixa de recolher a contribuição deduzida dos empregados. Há que se verificar no caso concreto o dolo, ainda que indireto, de não repassar o valor previamente descontado ao órgão estatal.

\footnotetext{
${ }^{147}$ Artigo 11 da Lei n ${ }^{\circ} 8.213 / 91$.

${ }^{148}$ Código Tributário Nacional, artigo 121, parágrafo único, II.

${ }^{149}$ Para Euro Bento Maciel Filho a opção legislativa da substituição tributária se dá por ser muito complexa a arrecadação desses valores se tudo dependesse de cada segurado-empregado, aduzindo ainda que $o$ empregador (ou a empresa) atua como mero intermediário entre o contribuinte - que são seus empregados e o agente arrecadador - que são os bancos (MACIEL FILHO, Euro Bento. Crimes Previdenciários. São Paulo: Juarez de Oliveira, 2004. p. 80-1).

${ }^{150}$ Lei $\mathrm{n}^{\text {o }}$ 8.212/91, artigo 30, I: a empresa é obrigada a: a) arrecadar as contribuições dos segurados empregados e trabalhadores avulsos a seu serviço, descontando-as da respectiva remuneração; b) recolher o produto arrecadado na forma da alínea $a$ deste inciso, a contribuição a que se refere o inciso IV do caput do art. 22 desta Lei, assim como as contribuições a seu cargo incidentes sobre as remunerações pagas, devidas ou creditadas, a qualquer título, aos segurados empregados, trabalhadores avulsos e contribuintes individuais a seu serviço até o dia 10 (dez) do mês seguinte ao da competência.

${ }^{151}$ Salvo os casos expressos em lei, ninguém pode ser punido por fato previsto como crime, senão quando o pratica dolosamente.
} 
O tipo penal do caput do artigo 168-A do Código Penal se configura com a verificação consecutiva de duas condutas: a subtração de parcela do salário a ser auferido pelo empregado e o apossamento em definitivo, de tal quantia, pelo empregador. O texto legal, ao referir-se à primeira conduta, usa o verbo recolher, assim: as contribuições recolhidas dos contribuintes. Recolher significa apanhar, guardar, retirar, mas também é verbo que se utiliza, no vocabulário jurídico, para indicar a ação de pagar tributos, como, por exemplo, na frase: a empresa recolheu imposto de renda. Portanto, se tomada essa última acepção, fica confusa e contraditória a redação do texto legal em análise, pois o empregado-contribuinte nada recolhe em favor da empresa. E, por outro lado, ainda que se considere serem os prepostos da rede bancária os únicos sujeitos ativos do caput do artigo em questão, a redação ainda se mostra dúbia, posto que o empregador não é contribuinte no que pertine à parcela descontada dos empregados, mas mero responsável. Mais claro seria o sentido da redação se fosse utilizada a expressão contribuições descontadas ou contribuições diminuídas ${ }^{152}$.

De volta ao texto legal, a conduta inicial é recolher dos empregados, que só se configura de forma comissiva.

É certo que, contemporaneamente, e a depender das rotinas adotadas por cada empregador, notadamente as pessoas jurídicas, o desconto da contribuição previdenciária se dá de modo automático. Grande parte das empresas se vale de programas de computador, que calculam mensalmente o valor a ser subtraído de cada empregado e indicam ao empregador a totalidade do valor a ser pago aos funcionários, já descontada a contribuição previdenciária. Assim, ao fazer o empenho do dinheiro a ser gasto com o salário de seus trabalhadores, o empresário já trabalha com o valor líquido, subtraído o valor da contribuição de cada um dos empregados. Mesmo assim, há que se convir, a conduta continua a ser comissiva. Ainda que não se repita a cada mês a ordem para o desconto, a cada mês ele ocorre, seguindo rotina previamente estabelecida por quem de direito dentro da organização empresarial. Essa primeira conduta, qual seja, o desconto, é

\footnotetext{
${ }^{152}$ Por conta dessa imprecisão terminológica, há autores que afirmam ser o caput do artigo 168-A aplicável somente à rede bancária, sendo que as empresas, por seus representantes legais, estariam sujeitas à norma do $\S 1^{\circ}$, I. Confira-se: no caput do art. 168-A do Código Penal, acrescentado pela Lei 9.983 de 14.07.2000, está criminalizada a conduta daquele que, ao receber as contribuições previdenciárias dos respectivos contribuintes, deixa de repassá-las para a Previdencia Social. Como a quase totalidade dos tributos são arrecadados pela rede bancária, cometerão esse crime os representantes legais ou empregados de instituição bancária que, ao receberem as contribuições previdenciárias recolhidas por uma empresa, deixarem de repassá-las aos cofres públicos (DIAS, Jefferson Aparecido. Crime de Apropriação Indébita Previdenciária. CP, art. 168-A, $\S 1^{\circ}$, inc. I. 2. ed. Curitiba: Juruá, 2007. p. 43).
} 
ato completamente lícito e, diga-se de passagem, determinado pela legislação previdenciária.

O crime apenas se aperfeiçoa com o não repasse dos valores descontados ao órgão previdenciário, no prazo legal. Aqui, nota-se que a conduta é omissiva, ou seja: para sua configuração deve o sujeito ativo manter-se inerte, sem praticar o ato que lhe é exigido pela legislação previdenciária. Essa segunda conduta é descrita no tipo penal pela locução deixar de repassar à previdência social. A norma penal exige que se cumpra uma obrigação, qual seja, entregar ao ente público o valor descontado dos empregados. A conduta, portanto, é negativa, de inação ${ }^{153}$.

Assim, com relação à conformação típica, exige-se a confluência de duas condutas por parte do sujeito ativo: o desconto e a ausência de repasse $e^{154}$. Note-se que, isoladamente, nenhuma das duas ações configura crime ${ }^{155}$. A falta do desconto - que, na prática, significaria a entrega integral do salário ao empregado - por óbvio não é crime. Também não há que se falar em ausência de repasse se não houve desconto. Claro está, pela conformação típica, que o delito apenas se configura quando ocorre o lançamento do desconto no holerite do empregado e tal valor, posteriormente, deixa de ser recolhido. Caso não seja efetivado o desconto não há que se falar em apropriação indébita previdenciária, ainda que o empregador possa vir a ser responsabilizado pelo não recolhimento das quantias. Para Henrique Geaquintino Herkenhoff, a conduta de quem deixa de realizar o

\footnotetext{
153 Alerta Hugo de Brito Machado que no caso do imposto de renda retido na fonte, ou das contribuições descontadas dos salários, embora possa parecer que há uma apropriação, na verdade ela não existe, porque o empregador, ao pagar o salário, ou a fonte, ao pagar o rendimento sujeito à incidência do imposto, na verdade está pagando parte de seu débito, e fica a dever o restante, a ser pago ao fisco. A relação jurídica, em qualquer desses casos, com o fisco, é uma relação de direito obrigacional (MACHADO, Hugo de Brito. Apropriação indébita e dívida de tributo. IOB - Repertório de Jurisprudência civil, processual, penal e comercial. São Paulo, n. 12, p. 229-30, jun. 1994).

${ }^{154}$ Cezar Roberto Bitencourt aponta, no mesmo sentido, que o desconto é pressuposto do crime: somente é possível repassar algo que se tenha recebido ou recolhido. O prefixo "re" tem, etimologicamente, esse sentido de repetição. Portanto, o sujeito ativo somente poderá repassar as contribuições quando as houver recolhido, pois somente assim terá sua posse $e$, não as repassando, poderá apropriar-se (BITENCOURT, Cesar Roberto. Tratado de Direito Penal - Parte Especial. v. 3. São Paulo: Saraiva, 2003. p. 255.)

${ }^{155}$ Parte da doutrina denomina a conduta descrita de mista, por haver uma conduta antecedente comissiva e outra, subsequiente, omissiva. Nesse exato sentido: SALOMÃO, Heloisa Estellita. Crimes Previdenciários: Arts 168-A e 337-A do CP - Aspectos Gerais. Revista Brasileira de Ciências Criminais. p. 309-50. Ano 9, out./dez. 2001.
} 
desconto contábil não corresponde à apropriação indébita previdenciária, podendo contudo constituir sonegação de contribuição previdenciária (...) ${ }^{156} 157$.

Heleno Cláudio Fragoso, citado por Ela Wiecko Volkner de Castilho ${ }^{158}$, conclui que

o atraso no recolhimento das contribuições não se equipara à apropriação indébita. A contribuição devida pelos empregados não é "arrecadada" pelo empregador, que paga sempre aos empregados o valor líquido dos salários. A arrecadação, no caso, é puramente ficta.

Mesmo sendo o iter criminis fracionado, em vista de a segunda conduta ser omissiva, não há possibilidade de configuração da modalidade tentada.

O crime, em que pesem percepções contrárias, é material ${ }^{159}$. Diz-se material o crime que só se torna perfeito com a realização do resultado fixado como característico pelo tipo penal ${ }^{160}$. O crime material, por convenção doutrinária, deve alterar a ordem natural das coisas, incidindo sobre a realidade e modificando-a. O agir de quem desconta, ainda que contabilmente, parcela da remuneração dos empregados e deixa de repassar tal montante aos cofres da seguridade social tem resultado concreto, qual seja, a transferência de disponibilidade econômica do empregado para a empresa. Há real alteração no mundo da percepção, consubstanciada pela subtração de quantia do contribuinte-empregado em favor do responsável-empregador de valor que deveria ser repassado aos cofres públicos,

${ }^{156}$ HERKENHOFF, Henrique Geaquintino. Novos crimes previdenciários. Rio de Janeiro: Forense, 2001. p. 10.

${ }^{157}$ Para Heloisa Estellita Salomão, deve-se chamar a atenção para o fato de que, embora entendemos que não haja exigência da apropriação da quantia descontada, deverá ela ter sido efetivamente descontada do pagamento feito ao segurado, ou seja, o numerário deve existir quando do pagamento e deve, posteriormente, deixar de ser recolhido pelo responsável tributário, a "empresa". Portanto, não basta o puro e simples não-recolhimento das contribuições previdenciárias devidas, é necessário seu anterior e real desconto dos pagamentos efetuados aos segurados e a terceiros (SALOMÃO, Heloisa Estellita. Novos Crimes Previdenciários - Lei n ${ }^{\circ}$ 9.983/00, de 14 de julho de 2000: Primeiras Impressões. Revista Dialética do Direito Tributário. São Paulo, n. 64, p. 70-90, jan. 2001).

${ }^{158}$ CASTILHO, Ela Wiecko Volkner de. Crimes contra a previdência social. Revista da Procuradoria-Geral da República. n. 8, p. 127-37, jan./jun. 1996.

${ }^{159}$ Para Cezar Roberto Bitencourt (Tratado de Direito Penal - Parte Especial. v. 3. São Paulo: Saraiva, 2003. p. 257); Euro Bento Maciel Filho (Crimes Previdenciários. São Paulo: Juarez de Oliveira, 2004. p. 83) e Henrique Geaquinto Herkenhoff (Novos Crimes Previdenciários. Rio de Janeiro: Forense, 2001. p. 9), o crime é formal. É crime material para Celso Delmanto et al (Código Penal Comentado. 6. ed. Rio de Janeiro: Renovar, 2002. p. 386), Roberto Podval e Paula Kahan Mandel (PODVAL, Roberto; MANDEL, Paula Kahan. Crimes de Apropriação Indébita e de Sonegação de Contribuição Previdenciária - Comentários Críticos à Lei n. 9.983, de 17.2.2000. Revista Dialética de Direito Tributário. São Paulo, n. 65, p. 106-22, fev. 2001).

${ }^{160}$ BRUNO, Aníbal. Direito Penal, parte geral. t. 2. 3. ed. Rio de Janeiro, 1967. p. 221. 
mas não o é. Assim, ainda que não se veja alterada a situação dos ativos da Previdência pois é da essência do crime a ausência do repasse - fica evidente a variação de fortuna do empregado. Este é o resultado naturalístico exigido para a consumação do tipo.

Sujeito ativo do delito em questão é o responsável pela arrecadação da contribuição, ou seja, o empregador. É ele quem desconta e deixa de repassar ou recolher (caput e incisos I e II) ou deixa de pagar benefício (inciso III). O sujeito ativo é próprio, posto que se exige dele qualidade especial, qual seja, ser o responsável legal pela obrigação tributária.

A questão do sujeito passivo do crime do artigo 168-A do Código Penal (caput e também dos incisos I e II do $\S 1^{\circ}$ ) está intimamente ligada à análise do bem jurídico tutelado $^{161}$. Para Henrique Geaquintino Herkenhoff, sujeito passivo é o sujeito ativo da obrigação tributária, normalmente o INSS ${ }^{162}$. Outros autores afirmam no mesmo sentido. Ao discorrer sobre os sujeitos passivos dos crimes previdenciários aduz Euro Bento Maciel Filho $^{163}$ :

já o sujeito passivo do crime, isto é, aquele que é vitimado pela prática criminosa, será, sempre, o Estado, mais precisamente a autarquia federal encarregada de gerir a previdência social - o INSS -, e, num segundo momento, poderá ser também o segurado, já que, em alguns casos, ele também é lesado pelo não recolhimento das contribuições previdenciárias que lhe foram descontadas.

Wagner Balera, que escreveu à luz da legislação anterior, revogada pela Lei $\mathrm{n}^{\circ}$ 9.983/00, aduz:

o sujeito passivo é o Estado, personificado na entidade que detém a capacidade tributária ativa. Mas na configuração desse modelo, além do INSS, pode ser considerado como sujeito passivo da infração penal o segurado a quem a lei confere o direito aos benefícios enumerados na alínea "f” do art. 95 (...) Caso, porém, o Instituto Nacional de Seguro Social efetue o pagamento desse benefício diretamente ao segurado - o que pode ser exigido por este - a sujeição passiva se restringe à autarquia previdenciária ${ }^{164}$.

\footnotetext{
${ }^{161}$ Capítulo 3.1.2.5, supra.

${ }^{162}$ HERKENHOFF, Henrique Geaquintino. Novos crimes previdenciários. Rio de Janeiro: Forense, 2001. p. 13.

${ }^{163}$ MACIEL FILHO, Euro Bento. Crimes Previdenciários. São Paulo: Juarez de Oliveira, 2004. p. 107 (sem esses grifos no original).

${ }^{164}$ BALERA, Wagner. Crime Tributário de Apropriação Indébita. Repertório de Jurisprudência IOB, São Paulo, n. 4, p. 83-6, fev. 1998.
} 
Referido autor admite a identidade entre o Estado e o INSS - Instituto Nacional do Seguro Social, com o que não se pode concordar, haja vista ter referido Instituto personalidade jurídica própria. Também não se pode aceder com a colocação do contribuinte-trabalhador como sujeito passivo, em razão da disposição legal do artigo 34 da Lei ${ }^{\circ} 8.213 / 91$.

\section{Como regra,}

o empregado e o avulso não são vítimas do delito, pois a omissão no recolhimento por parte do empregador ou tomador de serviços não lhes acarreta prejuízo direto (...) ${ }^{165}$.

Admite-se, todavia, o trabalhador contribuinte como sujeito passivo quando se está a falar da conduta descrita no inciso III do $\S 1^{\circ}$, pois nesta hipótese a seguridade ampara o trabalhador, remetendo-lhe o pagamento do benefício que fica retido pela empresa, responsável pelo repasse. Como se vê, o prejuízo toca, nesse caso, única e exclusivamente ao trabalhador, que fica impossibilitado de gozar do benefício que lhe fora concedido pelo Instituto e interceptado pela empresa.

Objeto material é o montante não pago ao trabalhador ou prestador de serviço por conta do desconto legalmente determinado. Ao deixar de cumprir com sua obrigação junto ao órgão arrecadador, o sujeito ativo faz própria a disponibilidade financeira que deveria transferir aos cofres públicos.

3.3.2 Sonegação de contribuição previdenciária (Código Penal, artigo 337-A)

Dispõe o artigo 337-A do Código Penal, introduzido pela Lei nº 9.983/00:

\section{Sonegação de contribuição previdenciária}

Art. 337-A. Suprimir ou reduzir contribuição social previdenciária e qualquer acessório, mediante as seguintes condutas:

I - omitir de folha de pagamento da empresa ou de documento de informações previsto pela legislação previdenciária segurados empregado, empresário, trabalhador avulso ou trabalhador autônomo ou a este equiparado que lhe prestem serviços;

II - deixar de lançar mensalmente nos títulos próprios da contabilidade da empresa as quantias descontadas dos segurados ou as devidas pelo empregador ou pelo tomador de serviços;

165 BALTAZAR JUNIOR, José Paulo. O crime de omissão no recolhimento de contribuições sociais arrecadadas. Porto Alegre: Livraria do Advogado, 2000. p. 104-5. 


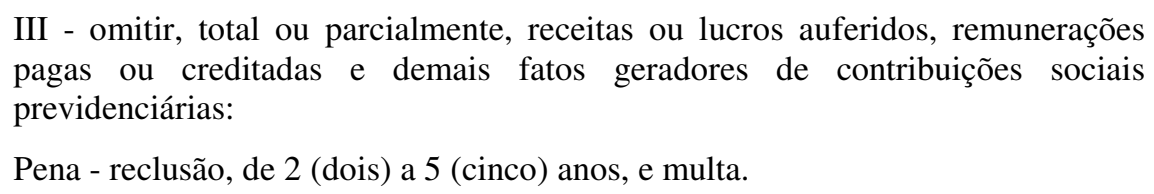

Tal qual o artigo 168-A do Código Penal, o dispositivo em estudo é norma penal em branco ${ }^{166}$. Sendo assim, algumas expressões que compõem o tipo penal devem ser analisadas, a fim de preencher de conteúdo a norma e delimitar, com a maior exatidão possível, quais condutas são abrangidas pelo tipo.

O conceito de acessórios é dado pelo Código Tributário Nacional ${ }^{167}$, que no artigo 113 distingue a obrigação principal da acessória. Assim, a obrigação principal surge com a ocorrência do fato gerador, tem por objeto o pagamento de tributo ou penalidade pecuniária e extingue-se juntamente com o crédito dela decorrente. Já a obrigação acessória decorre da legislação tributária e tem por objeto as prestações, positivas ou negativas, nela previstas no interesse da arrecadação ou da fiscalização dos tributos. As obrigações acessórias abrangem as multas, os juros e a atualização monetária da quantia devida $^{168}$.

A expressão empresa também tem definição legal na órbita do Direito Previdenciário. Conforme inciso I do artigo 15 da Lei $\mathrm{n}^{\circ}$ 8.212/91, trata-se da firma individual ou sociedade que assume o risco de atividade econômica urbana ou rural, com fins lucrativos ou não, bem como os órgãos e entidades da Administração Pública direta, indireta ou fundacional.

Fato gerador é uma situação definida em lei como necessária e suficiente ao nascimento da obrigação tributária. A definição é dada pelo artigo 114 do Código Tributário Nacional. A conceituação do elemento do tipo segurado, o prazo e periodicidade de recolhimento são os mesmos do crime do artigo 168-A do Código Penal $^{169}$.

\footnotetext{
${ }^{166}$ Muitas das características do tipo penal do artigo 337-A são semelhantes às já comentadas no capítulo 3.2.1, no qual se analisou o crime de apropriação indébita previdenciária do artigo 168-A do Código Penal. Assim, a fim de evitar repetições desnecessárias, por vezes se fará remissão àquele capítulo.

${ }^{167}$ Lei $\mathrm{n}^{\circ}$ 5.172, de 25 de outubro de 1966.

${ }^{168}$ Artigo 27, I, da Lei n ${ }^{\circ} 8.212 / 91$.

${ }^{169}$ Consultar capítulo 3.2.1.
} 
Ao se iniciar a análise da descrição da conduta criminosa evidencia-se um tipo de conduta vinculada ${ }^{170}$. Trata-se de construção normativa que prevê um resultado e também as formas pelas quais esse resultado deve ser obtido. Assim, o legislador determina o resultado e as condutas a serem evitadas. Nas palavras de Heloisa Estellita Salomão, todas essas condutas fraudulentas devem ter por escopo e conseqüência a supressão ou redução da quantia devida a título de contribuição social previdenciária, conforme claramente estabelecido no caput do artigo ${ }^{171}$.

O resultado é a supressão ou redução de contribuição previdenciária ou de qualquer de seus acessórios, e vem descrito no caput. As condutas são as enumeradas nos incisos I a III.

Suprimir tem o sentido de subtrair, retirar, e indica, no caso do tipo, o não recolhimento do montante total devido. Reduzir, embora tenha significado muito próximo, indica a diminuição parcial do valor ou, sob outro ponto de vista, pode-se falar que comete redução da contribuição quem a recolhe de forma incompleta, esvaziada, a menor do que é devido.

O crime é material, já que existe a necessidade da verificação de resultado, qual seja, a frustração da arrecadação. Ocorrido o fato gerador nasce expectativa de recolhimento do tributo que, se obstada, tem como resultado diminuição da arrecadação para a seguridade social.

O elemento subjetivo do tipo, por ausência de previsão legal em sentido contrário, é o dolo ${ }^{172}$.

\footnotetext{
${ }^{170}$ Tome-se como exemplo que serve bem a explicar a construção dos tipos de conduta vinculada o artigo 130 do Código Penal, o qual prescreve ser crime expor alguém, por meio de relações sexuais ou qualquer ato libidinoso, a contágio de moléstia venérea, de que sabe ou deve saber que está contaminado. O resultado não desejado pelo legislador é a exposição de alguém a contágio de moléstia venérea. $\mathrm{E}$ a forma de concretização desse resultado, a conduta, é a relação sexual. Fica estabelecido legalmente, portanto, um binômio condutaresultado, sendo que o crime só se tipifica pela realização do resultado, desde que esse seja ocasionado pela conduta prescrita (relação sexual). Assim, não se adequa à descrição típica do artigo 130 do Código Penal a exposição de alguém a contágio de moléstia venérea por qualquer meio que não a relação sexual. Neste diapasão, não configura o crime do artigo 130 do Código Penal expor alguém a contágio venéreo por meio da administração intravenosa, por seringa, de agente patogênico.
}

${ }^{171}$ SALOMÃO, Heloisa Estellita. Novos Crimes Previdenciários - Lei no 9.983/00, de 14 de julho de 2000: Primeiras Impressões. Revista Dialética do Direito Tributário. São Paulo, n. 64, p. 70-90, jan. 2001

${ }^{172}$ Verificar Código Penal, artigo 18, parágrafo único. 
A conduta é omissiva pura (ou própria), já que a norma tem o sentido de prescrever a obrigação de recolher as contribuições, impondo tal ônus às pessoas que se enquadram nas situações descritas pelos fatos geradores. Comete-se o crime descumprindo o comando da norma, ou seja, não recolhendo as contribuições. Note-se que os verbos e locuções dos incisos são omitir (incisos I e III) e deixar de lançar (inciso II). Indicam, portanto, inações ou ações negativas.

Surge, porém, interessante questão ao se analisar o tipo verbal reduzir que, conforme supramencionado, descreve a conduta daquele que recolhe a contribuição em montante menor do que será devido. Se ocorrer recolhimento parcial, está-se diante de ação positiva, e não de ação negativa, o que poderia levar à conclusão de ser o crime, nesse caso específico (reduzir), comissivo. Tal raciocínio, entretanto, não vence uma análise mais apurada da questão. Muito embora o sujeito ativo tenha agido positivamente, desempenhando a ação de recolhimento parcial, não é por esse fato (ação) que será incriminado. Ainda quando ocorre o recolhimento parcial - que sem dúvida é ação positiva - a conduta punida é a omissão de recolhimento da parcela restante, o que leva a concluir que mesmo na modalidade reduzir trata-se de crime omissivo.

O sujeito ativo é o empregador ou tomador de serviço, e tal questão não apresenta maiores dificuldades em razão da descrição legal. É próprio, portanto.

Com relação ao sujeito passivo assevera Euro Bento Maciel Filho que será, sempre, o Instituto Nacional de Seguridade Social - INSS, já que é a Autarquia Federal responsável pela fiscalização e arrecadação das contribuições sociais ${ }^{173}$. Na mesma linha vem Henrique Geaquintino Herkenhoff ${ }^{174}$ : sujeito passivo é o sujeito ativo da obrigação tributária: em princípio o INSS. Tal questão, assim como no crime de apropriação indébita de contribuição previdenciária, tem íntima ligação com a discussão acerca do bem jurídico tutelado ${ }^{175}$.

Objeto material do crime é a contribuição social previdenciária, ou seus acessórios, como multas, atualização monetária e juros moratórios ${ }^{176}$. É para tutelar sua

\footnotetext{
${ }^{173}$ MACIEL FILHO, Euro Bento. Crimes Previdenciários. São Paulo: Juarez de Oliveira, 2004. p. 121.

${ }^{174}$ HERKENHOFF. Henrique Geaquintino. Novos crimes previdenciários. Rio de Janeiro: Forense, 2001. p. 33.

${ }^{175}$ Conferir capítulo 3.1.2.5.

${ }^{176}$ Conforme dispõe o artigo 27, I, da Lei n ${ }^{\circ} 8.212 / 91$.
} 
escorreita arrecadação que existe o tipo incriminador; ela é o que visa o sujeito ativo, fazendo sua a disponibilidade econômica que, por determinação da legislação previdenciária, deveria ser transferida ao órgão competente.

Pode-se apontar, também, como objetos materiais do crime a folha de pagamento ou documento de informações (inciso I) e os títulos próprios da contabilidade da empresa (inciso II). Os dados inseridos em tais documentos são os que, ideologicamente falsos, permitem ao sujeito ativo do crime deixar de recolher a contribuição devida.

3.3 Comparação entre os tipos penais

Os tipos penais de apropriação indébita previdenciária e sonegação de contribuição previdenciária, objeto do presente estudo, foram introduzidos no Código Penal pela Lei $n^{\circ}$ 9.983/00. É de se esperar, portanto que tenham como objeto de tutela o mesmo bem jurídico, como de fato têm. As penas cominadas aos tipos são idênticas, quais sejam, reclusão, de 2 (dois) a 5 (cinco) anos, e multa ${ }^{177}$.

Mesmo sendo idênticas as penas, será que se pode dizer tenham as condutas descritas o mesmo desvalor ${ }^{178}$ ? Para responder à questão cabem duas distintas linhas de investigação.

A apropriação indébita previdenciária e a sonegação de contribuição previdenciária são condutas que frustram a arrecadação para a seguridade social. Portanto, a prática de qualquer dos delitos onera igualmente os cofres públicos, turbando a disponibilidade financeira do órgão previdenciário. Sob essa ótica parece que não haveria, do ponto de vista do desvalor da conduta, nenhuma diferença entre a apropriação indébita e a sonegação. Tal conclusão, nesse primeiro ponto de vista, é verdadeira. Conforme já se teve oportunidade de analisar quando do estudo em separado da apropriação indébita previdenciária $^{179}$, o desconto e retenção de parcela do salário do trabalhador, por parte do

\footnotetext{
${ }^{177}$ Referida pena também é a aplicada aos crimes contra a ordem tributária, artigos $1^{\circ}$ e $2^{\circ}$ da Lei no $8.137 / 90$.

${ }^{178} \mathrm{O}$ tanto quanto possível deve o Direito Penal respeitar a proporcionalidade das sanções, medida que é dada pelo desvalor da conduta. Assim, quanto mais desvalor a conduta carregar maior deve ser a reprimenda, e vice-versa.

${ }^{179}$ Conferir capítulos 3.2.1.3.
} 
empregador, é mera ficção jurídica. Na verdade, o empregador possuiu dois compromissos: em determinado momento do mês tem obrigação de pagar os salários dos trabalhadores (aqui, o montante a ser despendido não leva em consideração o valor bruto dos salários, mas a parcela líquida, já descontada a fração "retida" a título de contribuição pessoal do trabalhador) e, num segundo momento, o empregador tem obrigação de cumprir sua responsabilidade junto ao órgão previdenciário de arrecadação (aqui, serão recolhidos os valores que fictamente foram descontados dos empregados e também os relativos à contribuição patronal).

Portanto, o que o empregador apresenta ao órgão previdenciário é a soma dos valores "descontados" - que recolhe como responsável tributário - e dos valores que efetivamente deve a título de contribuição do empregador - que recolhe como sujeito passivo da obrigação tributária. Logo, percebe-se que tanto o "caixa de saída" (empregador) como o "caixa de entrada" (seguridade social) são os mesmos. Isso indicaria não haver diferenciação, do ponto de vista valorativo, entre um delito e outro.

De outro ponto de vista, entretanto, a conduta de sonegação de contribuição previdenciária parece encerrar maior desvalor. É que ela exige, pela conformação típica do artigo 337-A do Código Penal, a realização de um plus, uma conduta pré-ordenada que prepara e possibilita tenha sucesso a sonegação. Com efeito, para que se atinja a efetiva sonegação, deve o agente praticar um falso ideológico, seja omitindo dados na folha de pagamento (inciso I), seja deixando de lançar dados de quantias descontadas dos segurados ou devidas por si (inciso II) ou, ainda, omitindo total ou parcialmente receitas, lucros auferidos, remunerações pagas ou creditadas ou demais fatos geradores da contribuição (inciso III).

Assim, parece ser mais intenso o dolo da conduta daquele que desempenha uma ação prévia de falsidade, abrindo caminho para a consecução da sonegação, se comparada à conduta daquele que regularmente escritura, no holerite e folha de pagamento, a retenção de fração dos vencimentos dos empregados.

Invertendo a ordem cronológica dos fatos é possível perceber que, no dia em que as contribuições devem ser recolhidas (seja a parcela descontada dos empregados, seja a parcela da contribuição patronal), o empregador pratica a ação dolosa de deixar de recolher. Ocorre que, na sonegação de contribuição previdenciária, antes desse momento, 
o dolo de não recolhimento já se evidenciou, pois o agente já cuidara de falsificar dados, em documentos contábeis, que possibilitaram o não recolhimento. Há, portanto, na sonegação de contribuição previdenciária, a vontade de iludir os órgãos de fiscalização, omitindo informações que possibilitem auferir o real montante devido.

Pode-se, assim, concluir pelo maior desvalor da conduta de sonegação de contribuição previdenciária, em que pese a igual cominação de penas.

No que se refere à extinção da punibilidade, o legislador adotou diferentes medidas, tratando mais gravosamente o crime de apropriação indébita previdenciária. A desigual forma de tratamento adotada pelo Código Penal ${ }^{180}$ foi equalizada pelo artigo $9^{\circ} \S$ $2^{\circ}$ da Lei $n^{\circ} 10.684 / 03$, conforme será abordado no capítulo 5.2, infra.

${ }^{180}$ Com redação dada pela Lei $n^{\circ} 9.983 / 00$. 


\title{
4 DIREITO COMPARADO
}

\author{
4.1 Legislação portuguesa
}

O Regime Geral das Infracções Tributárias (RGIT), aprovado pela Lei $\mathrm{n}^{\mathrm{o}}$ 15/01, de 5 de junho de 2001, define, em seu capítulo IV, os crimes contra a segurança social, em dois artigos ${ }^{181}$. Confira-se:

\section{Artigo $106^{\circ}$ - Fraude contra a segurança social}

1- Constituem fraude contra a segurança social as condutas das entidades empregadoras, dos trabalhadores independentes e dos beneficiários que visem a não liquidação, entrega ou pagamento, total ou parcial, ou o recebimento indevido, total ou parcial, de prestações de segurança social com intenção de obter para si ou para outrem vantagem patrimonial ilegítima de valor superior a $€$ 7500 .

2- É aplicável à fraude contra a segurança social a pena prevista no $\mathrm{n}^{\circ} 1$ do artigo $103^{\text {o182 }}$ e o disposto nas alíneas a) a c) do $n^{\circ} 1^{183}$ e no $n^{o} 3^{184}$ do mesmo artigo.

3- É igualmente aplicável às condutas previstas no $\mathrm{n}^{\mathrm{o}} 1$ deste artigo o disposto no artigo $104^{\text {o185 }}$.

4- Para efeito deste artigo também se consideram prestação da segurança social os benefícios previstos na legislação da segurança social.

\section{Artigo $107^{\circ}$ - Abuso de confiança contra a segurança social}

1- As entidades empregadoras que, tendo deduzido do valor das remunerações devidas a trabalhadores e membros dos órgãos sociais o montante das contribuições por estes legalmente devidas, não o entreguem, total ou parcialmente, às instituições de segurança social, são punidas com as penas previstas nos $n^{\circ} \mathrm{s} 1^{186}$ e $5^{187}$ do artigo $105^{\circ}$.

2- É aplicável o disposto nos $n^{\circ} s 4^{188}, 6^{189}$ e $7^{190}$ do artigo $105^{\circ}$.

${ }^{181}$ Disponível em <http://www.inforfisco.pt/Codigos/RGIT.pdf>, acesso em 12.dez.2007.

${ }^{182}$ Pena de prisão até três anos ou multa até 360 dias.

183 a) Ocultação ou alteração de factos ou valores que devam constar dos livros de contabilidade ou escrituração, ou das declarações apresentadas ou prestadas a fim de que a administração fiscal especificamente fiscalize, determine, avalie ou controle a matéria colectável; b) Ocultação de factos ou valores não declarados e que devam ser revelados à administração tributária; c) Celebração de negócio simulado, quer quanto ao valor, quer quanto à natureza, quer por interposição, omissão ou substituição de pessoas.

${ }^{184}$ Para efeitos do disposto nos números anteriores, os valores a considerar são os que, nos termos da legislação aplicável, devam constar de cada declaração a apresentar à administração tributária.

185 Prisão de um a cinco anos para as pessoas singulares e multa de 240 a 1200 dias para as pessoas colectivas, em hipóteses específicas cumuladas como, por exemplo, o agente falsificar ou viciar, ocultar, destruir, inutilizar ou recusar entregar, exibir ou apresentar livros, programas ou ficheiros informáticos e quaisquer outros documentos ou elementos probatórios exigidos pela lei tributária.

${ }^{186}$ Pena de prisão até três anos ou multa até 360 dias.

${ }^{187}$ Quando a entrega não efectuada for superior a $€ 50.000$, a pena é a de prisão de um a cinco anos e de multa de 240 a 1200 dias para as pessoas colectivas.

${ }^{188}$ Os factos descritos nos números anteriores só são puníveis se: 
Resta claro, da análise da legislação portuguesa, que o artigo $106^{\circ}$ abarca, entre outras, a conduta do caput do artigo 337-A do Código Penal, qual seja, a sonegação de contribuição previdenciária, haja vista a previsão de punição, na norma lusitana, da conduta de não liquidação, entrega ou pagamento.

O dispositivo comentado, entretanto, vai além da legislação brasileira, criminalizando, por exemplo, o recebimento indevido, total ou parcial, de prestações de segurança social com intenção de obter para si ou para outrem vantagem patrimonial ilegítima. Entre nós, não existe tipo específico para tal situação, ficando a punição, quando caracterizada tal conduta, a cargo do estelionato do artigo 171 do Código Penal ${ }^{191}$.

$\mathrm{O}$ artigo $106^{\circ}$ fixa um montante mínimo para que o Direito Penal passe a atuar, qual seja, € 7.500. Ficam, assim, imunes à persecução penal condutas de relativo vulto, mas que não são consideradas, ao que parece, carecedoras de sanção penal. Com relação a esse aspecto específico, a lei brasileira prevê mecanismos semelhantes:

\begin{abstract}
Art. 337-A (...)
$\$ 2^{\circ}$. É facultado ao juiz deixar de aplicar a pena ou aplicar somente a de multa se o agente for primário e de bons antecedentes, desde que

II- o valor das contribuições devidas, inclusive acessórios, seja igual ou inferior àquele estabelecido pela previdência social, administrativamente, como sendo o mínimo para o ajuizamento de suas execuções fiscais.

$\S 3^{\circ}$. Se o empregador não é pessoa jurídica e sua folha de pagamento mensal não ultrapassa $\mathrm{R} \$ 1.510,00$ (um mil quinhentos e dez reais), o juiz poderá reduzir a pena de um terço, até a metade, ou aplicar apenas a de multa ${ }^{192}$.
\end{abstract}

a) Tiverem decorrido mais de 90 dias sobre o termo do prazo legal de entrega da prestação;

b) A prestação comunicada à administração tributária através da correspondente declaração não for paga, acrescida dos juros respectivos e do valor da coima aplicável, no prazo de 30 dias após notificação para o efeito.

${ }^{189}$ Se o valor da prestação a que se referem os números anteriores não exceder $€ 2.000$, a responsabilidade criminal extingue-se pelo pagamento da prestação, juros respectivos e valor mínimo da coima aplicável pela falta de entrega da prestação no prazo legal, até 30 dias após a notificação para o efeito pela administração tributária.

${ }^{190}$ Para efeitos do disposto nos números anteriores, os valores a considerar são os que, nos termos da legislação aplicável, devam constar de cada declaração a apresentar à administração tributária.

${ }^{191}$ Imagine-se a hipótese de contribuinte que pleiteie e obtenha aposentadoria junto à previdência social utilizando-se de anotações falsas em sua Carteira de Trabalho e Previdência Social (CTPS). Sob a ótica da legislação portuguesa trata-se de crime contra a segurança da seguridade social, punido pelo artigo $106^{\circ}$ mas, no Brasil, essa fraude não é punida pelo crime previdenciário, restando a subsidiária punição pelo estelionato.

${ }^{192}$ A portaria $n^{o}$ 342, de 16 de agosto de 2006, do Ministério da Previdência Social,determina que, a partir de $1^{o}$ de agosto de 2006, o valor estabelecido neste parágrafo será de $R \$ 2.473,55$ (dois mil quatrocentos e setenta e três reais e cinqüenta e cinco centavos). 
A lei penal brasileira exige, além do requisito de ínfima lesão, a primariedade e os bons antecedentes do agente, no que diz às benesses previstas no $\S 2^{\circ}$, o que não ocorre com a norma de Portugal.

Enquanto a lei portuguesa considera atípicas as condutas que não alcancem o piso determinado legalmente, o sistema brasileiro trabalha com o perdão judicial (deixar de aplicar a pena) ou a diminuição da reprimenda (aplicar somente a pena de multa ou reduzir a pena corporal de um terço até a metade).

No estatuto português, para a figura básica do artigo $106^{\circ}$ a pena privativa de liberdade é de até três anos; sofre aumento, para mínimo de um e máximo de cinco, entretanto, em hipóteses específicas. Com relação a esse aspecto, encontra-se considerável variação na pena mínima das figuras básicas, se comparadas as duas legislações, sendo muito elevada - dois anos - a reprimenda fixada no Brasil. Equipara-se o artigo $107^{\circ}$ da norma portuguesa à apropriação indébita previdenciária, do artigo 168-A de nosso Código Penal. De se notar que entre os portugueses a conduta também é descrita em duas fases ${ }^{193}$, quais sejam, não entregar os valores após os ter deduzido.

Na legislação estrangeira existe um teto monetário que, se ultrapassado, induz a aplicação de pena mais elevada: no caso da apropriação de valores superiores a $€ 50.000$, a pena de até três anos passa a ser mínima de um e máxima de cinco anos. Interessante destacar, ainda, que na legislação portuguesa a punibilidade só se faz presente para o crime de abuso de confiança contra a segurança social se é excedido o prazo de noventa dias da data estipulada para o pagamento. Cite-se, por fim, que em ambos os artigos relacionados $\left(106^{\circ}\right.$ e $\left.107^{\circ}\right)$ admite-se a punição, com pena de multa, para as pessoas jurídicas (pessoas colectivas).

\subsection{Legislação italiana}

Dispõe o artigo 37 da Lei $n^{\circ} 689$, de 24 de novembro de $1981^{194}$, que guarda relação com o crime de sonegação de contribuição previdenciária do nosso ordenamento:

\footnotetext{
${ }^{193}$ Confira-se capítulo 3.2.1.

${ }^{194}$ Disponível em <http://www.giustizia.it/cassazione/leggi/1689_81.html>, acesso em 12.dez.2007.
} 


\section{Art. 37 - Omissione o falsità in registrazione o denuncia obbligatoria}

Salvo che il fatto costituisca più grave reato, il datore di lavoro che, al fine di non versare in tutto $\mathrm{o}$ in parte contributi e premi previsti dalle leggi sulla previdenza e assistenza obbligatorie, omette una o più registrazioni o denunce obbligatorie, ovvero esegue una o più denunce obbligatorie in tutto $\mathrm{o}$, in, parte, non conformi al vero, è punito con la reclusione fino a due anni quando dal fatto deriva l'omesso versamento di contributi e premi previsti dalle leggi sulla previdenza e assistenza obbligatorie per un importo mensile non inferiore al maggiore importo fra cinque milioni mensili e il cinquanta per cento dei contributi complessivamente dovuti.

Fermo restando l'obbligo dell'organo di vigilanza di riferire al pubblico ministero la notizia di reato, qualora l'evasione accertata formi oggetto di ricorso amministrativo o giudiziario il procedimento penale è sospeso dal momento dell'iscrizione della notizia di reato nel registro di cui all'articolo 335 del codice di procedura penale, fino al momento della decisione dell'organo amministrativo o giudiziario di primo grado.

La regolarizzazione dell'inadempienza accertata, anche attraverso dilazione, estingue il reato.

Entro novanta giorni l'ente impositore è tenuto a dare comunicazione all'autorità giudiziaria dell'avvenuta regolarizzazione o dell'esito del ricorso amministrativo o giudiziario.

Alguns aspectos da legislação italiana a fazem muito próxima da brasileira. Por exemplo, a construção de um tipo de conduta vinculada, com descrição de um resultado (al fine di non versare in tutto o in parte contributi e premi previsti dalle leggi sulla previdenza e assistenza obbligatorie) e condutas pelas quais se lhe atinge (omette una o più registrazioni o denunce obbligatorie, ovvero esegue una o più denunce obbligatorie in tutto o, in, parte). Na lei brasileira o resultado é suprimir ou reduzir contribuição social previdenciária e qualquer acessório, e são três as condutas previstas: incisos I, II e III do caput do artigo 337-A do Código Penal.

A lei penal italiana só pune condutas de sonegação de contribuição previdenciária se o valor mensal for superior a cinco milhões de liras ou superior a mais da metade da contribuição devida no mês, o que for maior. Assim, ainda que o empregador deixe de recolher dez milhões de liras, por exemplo, tal conduta não será punida se esse valor não for superior à metade do que deve ser recolhido.

De se destacar, ainda, a previsão de suspensão do procedimento penal enquanto pende decisão administrativa ou judiciária de primeiro grau acerca do objeto do débito (il procedimento penale è sospeso dal momento dell'iscrizione della notizia di reato nel registro di cui all'articolo 335 del codice di procedura penale, fino al momento della 
decisione dell'organo amministrativo o giudiziario di primo grado $)^{195}$. A pena máxima é de dois anos na lei italiana, o que demonstra punição bem mais branda que a da legislação brasileira, em que a pena mínima é de dois anos. Pela lei italiana, a regularização do inadimplemento (regolarizzazione dell'inadempienza) extingue o crime.

Pouco tempo depois da regulamentação do crime de omissione o falsità in registrazione o denuncia obbligatoria, o Decreto-Lei $\mathrm{n}^{\circ} 463$, de 11 de setembro de 1983, convertido na Lei $\mathrm{n}^{\mathrm{o}}$ 638, de 11 de novembro de 1983, a qual foi posteriormente modificada pelos Decretos-Legislativos no 338, de 9 de outubro de 1989, e $\mathrm{n}^{\circ} 211$, de 24 de março de 1994, normatizou o crime de apropriação indébita previdenciária. O texto legal, depois de processadas as alterações, ficou assim redigido ${ }^{196}$ :

1. Le ritenute previdenziali ed assistenziali operate dal datore di lavoro sulle
retribuzioni dei lavoratori dipendenti, ivi comprese le trattenute effettuate ai
sensi degli articoli 20,21 e 22 della legge 30 aprile $1969, \mathrm{n}$. 153, debbono essere
comunque versate e non possono essere portate a conguaglio con le somme
anticipate, nelle forme e nei termini di legge, dal datore di lavoro ai lavoratori
per conto delle gestioni previdenziali ed assistenziali, e regolarmente denunciate
alle gestioni stesse, tranne che a seguito di conguaglio tra gli importi contributivi
a carico del datore di lavoro e le somme anticipate risulti un saldo attivo a favore
del datore di lavoro. 1-bis. L'omesso versamento delle ritenute di cui al comma primo è punito con la
reclusione fino a tre anni e con la multa fino a lire due milioni. Il relativo versamento entro sei mesi dalla scadenza della data stabilita per lo stesso e comunque, ove sia fissato il dibattimento prima di tale termine, non oltre le formalità di apertura del dibattimento stesso, estingue il reato.

1-ter. La denuncia di reato é presentata o trasmessa senza ritardo dopo il versamento di cui al comma 1-bis ovvero decorso inutilmente il termine ivi previsto. Alla denuncia é allegata l'attestazione delle somme eventualmente versate.

1-quater. Durante il termine di cui al comma 1-bis il corso della prescrizione rimane sospeso.

Com relação à pena privativa de liberdade cominada, tanto a mínima como a máxima são significativamente inferiores às adotadas no Brasil. Cumulativamente aplicase pena de multa, de até dois milhões de liras.

\footnotetext{
195 Pode-se traçar um pararelo com os artigos 93 e 94 do nosso Código de Processo Penal, que tratam das questões prejudiciais.

${ }^{196}$ Compilação dos textos legais disponíveis em <http://normativo.inail.it/BDNInternet/docs/dl46383.htm> e <http://www.csmb.unimo.it/index/nazionale/decretolegge_338_1989.pdf>, acesso em 13.dez.2007.
} 


\subsection{Legislação espanhola}

O Código Penal Espanhol, Lei Orgânica 10/95, publicado no Boletim Oficial do Estado (BOE) de 24 de novembro de $1995^{197}$ normatiza, no Título XIV do Livro II los delitos contra la hacienda pública y contra la seguridad social. Prescreve o artigo 307 do citado diploma legal:

1. El que, por acción u omisión, defraude a la Seguridad Social eludiendo el pago de las cuotas de ésta y conceptos de recaudación conjunta, obteniendo indebidamente devoluciones de las mismas o disfrutando de deducciones por cualquier concepto asimismo de forma indebida, siempre que la cuantía de las cuotas defraudadas o de las devoluciones o deducciones indebidas exceda de 120.000 euros será castigado con la pena de prisión de uno a cuatro años y multa del tanto al séxtuplo de la citada cuantía.

Las penas señaladas en el párrafo anterior se aplicarán en su mitad superior cuando la defraudación se cometa concurriendo alguna de las circunstancias siguientes:

a) La utilización de persona o personas interpuestas de manera que quede oculta la identidad del verdadero obligado frente a la Seguridad Social.

b) La especial trascendencia y gravedad de la defraudación atendiendo al importe de lo defraudado o a la existencia de una estructura organizativa que afecte o pueda afectar a una pluralidad de obligados frente a la Seguridad Social.

2. A los efectos de determinar la cuantía mencionada en el apartado anterior, se estará a lo defraudado en cada liquidación, devolución o deducción, refiriéndose al año natural el importe de lo defraudado cuando aquéllas correspondan a un período inferior a doce meses.

3. Quedará exento de responsabilidad penal el que regularice su situación ante la Seguridad Social, en relación con las deudas a que se refiere el apartado primero de este artículo, dirigidas a la determinación de dichas deudas o, en caso de que tales actuaciones no se hubieran producido, contra aquél dirigida.

La exención de responsabilidad penal contemplada en el párrafo anterior alcanzará igualmente a dicho sujeto por las posibles falsedades instrumentales que, exclusivamente en relación a la deuda objeto de regularización, el mismo pudiera haber cometido con carácter previo a la regularización de su situación.

As condutas criminosas descritas só adquirem tipicidade se os valores subtraídos à arrecadação forem superiores a $€ 120.000$, o que certamente só traz punição às empresas que contam grande número de empregados.

Destaca-se que a lei espanhola isenta de responsabilidade (quedará exento de responsabilidad) o agente que antes da atuação dos órgãos encarregados (antes de que se le haya notificado la iniciación de actuaciones inspectoras o antes de que el Ministerio Fiscal o el Letrado de la Seguridad Social interponga querella o denuncia), regularize sua

197 Disponível em <http://www.060.es/te_ayudamos_a/legislacion/disposiciones/7734-ides-idweb.html>, acesso em 13.dez.2007. 
situação junto à seguridade social (regularice su situación ante la Seguridad Social). Ocorrendo dita regularização, é expressa a extensão da isenção às condutas fraudulentas que tenham servido de meio à consecução do fato típico referente à dívida objeto da persecução penal $^{198}$.

No que concerne à pena privativa de liberdade, é mínima de um e máxima de quatro anos, com patamares próximos aos da legislação do Brasil, se bem que, ainda, inferiores. No entanto, ocorrendo alguma das hipóteses descritas nas letras "a" e "b", a pena privativa de liberdade mínima passa a ser de dois anos. A pena de multa, aplicada cumulativamente à de prisão, deve ser fixada em valor que varia do equivalente à quantia não arrecadada até seis vezes tal montante. Trata-se de interessante solução, que adequa a pena cominada à lesão que se causou.

\footnotetext{
${ }^{198}$ Embora não expressamente prevista tal extensão em lei, referindo-se à jurisprudência pátria, Rodrigo Sánches Ríos afirma que se está, por aqui, seguindo a mesma orientação: (...) estendem-se os benefícios decorrentes da exceção de responsabilidade penal às condutas delitivas acessórias, sempre que essas tenham um papel secundário e estejam voltadas unicamente à lesão do bem jurídico tutelado no crime previdenciário (RÍOS, Rodrigo Sánches. Das Causas de Extinção da Punibilidade nos Delitos Econômicos. São Paulo: RT, 2003. p. 164).
} 


\title{
5 OS CAMINHOS OBTUSOS DA DESCRIMINALIZAÇÃO: EXTINÇÃO DA PUNIBILIDADE PELO PAGAMENTO
}

\author{
5.1 Introdução: punibilidade
}

A questão acerca da natureza jurídica da punibilidade parece ter se pacificado $^{199}$. Discutiu-se muito se a punibilidade integraria o conceito de delito, idéia que é rechaçada pela quase totalidade dos doutrinadores de hoje.

Para Franz von Liszt, as condições de punibilidade são circumstancias exteriores, que nada têm de commum com o acto delituoso mesmo e seus elementos, e que, pelo contrario, devem ser considerados completamente distinctos destes ${ }^{200}$. Nesse sentido:

\begin{abstract}
a punibilidade é conseqüência do crime, não podendo ser considerada um seu elemento, como pretendeu Giulio Battaglini. Elemento é uma condição necessária à existência de todo o fenômeno, sendo, portanto, algo que o precede. A punibilidade, ao contrário, é um posterius com relação ao crime, do qual se origina. Praticada a ação delituosa surge o direito subjetivo do Estado de impor a sanção ao infrator, direito que se expressa na chamada pretensão punitiva ${ }^{201}$.
\end{abstract}

No mesmo diapasão são as lições de João Mestieri: delito é a ação humana, típica e culpável. Punibilidade não é elemento constitutivo do crime, mas a conseqüência de se reconhecer presentes os seus elementos constitutivos ${ }^{202}$. Assim para o autor, a punibilidade seria uma decorrência do delito, que pode ser obstada em específicos casos. Vale dizer: ao delito, como regra, segue-se a punibilidade, mas essa relação não é necessária e pode ser frustrada mediante a ocorrência de determinados fenômenos.

A verificação do delito faz agir o poder estatal de punir. Mais do que um poder, o Estado tem dever de mover seu aparato persecutório contra o autor de conduta nociva ao tecido social.

\footnotetext{
${ }^{199}$ DOTTI, René Ariel. Teoria Geral da Punibilidade. Revista CEJ. Brasília. v. 3. n. 7. p. 24-31. abr. 1999.

${ }^{200}$ LISZT, Franz von. Tratado de Direito Penal allemão. trad. José Hygino Duarte Pereira. Brasília: Senado Federal, 2006. p. 308 (grafia original da tradução).

${ }^{201}$ COSTA JR., Paulo José. Direito Penal. Curso Completo. 5. ed. São Paulo: Saraiva, 1999. p. 224.

${ }^{202}$ MESTIERI, João. Manual de Direito Penal. Parte Geral. v. 1. Rio de Janeiro: Forense, 1999. p. 315.
} 
Francesco Antolisei ${ }^{203}$, no mesmo sentido, não empresta à punibilidade status de elemento do delito, mas a considera conseqüência jurídica deste,

devendo ser aplicada a sanção quando se verificar que houve o crime e a conduta do agente for culpável. Com a prática do crime, o direito de punir do Estado, que era abstrato, torna-se concreto, surgindo a punibilidade, que é a possibilidade jurídica de impor a sanção.

Para René Ariel Dotti, a punibilidade é uma das condições para o exercício da ação penal (CPP, art. 43, II) e pode ser definida como a possibilidade jurídica do estado aplicar a sanção penal (pena ou medida de segurança) ao autor do crime ${ }^{204}$.

Acrescente-se a esses conceitos que a efetiva pena só poderá ser imposta após o trânsito em julgado da condenação, proferida após o desenrolar do devido processo legal (nulla poena sine iudicio), tal qual leciona Celso Delmanto, para quem a punibilidade é a possibilidade jurídica de impor pena ao violador da norma penal ${ }^{205}$.

Portanto, falar de punibilidade não é falar de delito, mas de uma consequiência lógica e jurídica deste. No entanto, em alguns casos, interpõe-se entre o delito e a punibilidade um acontecimento que impede o Estado de exercer o ius puniendi. Conforme já mencionado, ao delito segue-se a punibilidade, relação essa que não se verifica incondicionalmente. Há situações em que a norma penal impede que do delito, como consequiência lógica, deflua a punibilidade. Está-se diante, nesses casos, de causas extintivas da punibilidade, as quais têm o condão de obstar que a partir do crime siga-se a punição.

Interessante a dicotomia citada por Rodrigo Sánches $\operatorname{Ríos}^{206}$, que divide a punibilidade em concreta e abstrata:

tem se entendido, desta forma, que o enfoque "abstrato" configuraria o momento
normativo da punibilidade, e o "concreto", o seu momento aplicativo. O primeiro
refere-se, de fato, à existência de uma cominação de pena em abstrato, e o
segundo está voltado à concreta e efetiva aplicação da sanção penal.

${ }^{203}$ Citado em MIRABETE, Julio Fabbrini. Manual de Direito Penal. v. 1. 21 ed. São Paulo: Atlas, 2004. p. 383.

${ }^{204}$ DOTTI, René Ariel. Curso de Direito Penal. Parte Geral. Rio de Janeiro: Forense, 2003. p. 670.

${ }^{205}$ DELMANTO, Celso et al. Código Penal Comentado. 6. ed. Rio de Janeiro: Renovar, 2002. p. 202.

${ }^{206}$ RÍOS, Rodrigo Sánches. Das Causas de Extinção da Punibilidade nos Delitos Econômicos. São Paulo: RT, 2003. p. 25. 
As causas de extinção da punibilidade, portanto, são hipóteses legais que impedem a punibilidade, mesmo em face da verificação do delito. $\mathrm{O}$ abstrato direito estatal de punir, impedido pela causa extintiva, não se concretiza. René Ariel Dotti, ao conceituar as causas extintivas da punibilidade fala em atos ou fatos que impedem a aplicação da sanção penal ${ }^{207}$.

Janaina Conceição Paschoal aborda o tema sob outro aspecto: praticado um crime, não estando presentes quaisquer causas de extinção da punibilidade, o Estado está livre para promover a ação penal correspondente ao crime perpetrado e punir o agente por sua prática ${ }^{208}$.

O Direito Penal brasileiro, em alguns casos, passou a adotar para crimes que envolvam quantias patrimoniais a extinção da punibilidade pelo pagamento, com o que se recompõe a situação monetária do sujeito passivo, como se a conduta delituosa não tivesse existido.

Fica franqueada, assim, extensa hipótese de exceção à aplicação da lei penal a fatos que são considerados típicos, ilícitos e culpáveis, verdadeira "descriminalização", que segue tortuosos caminhos.

5.2 O Código Penal, as Leis $\mathrm{n}^{\circ}$ 9.964/00 (REFIS I), $\mathrm{n}^{\circ}$ 10.684/03 (REFIS II ou PAES) e a Medida Provisória n 303/06 (Refis III ou PAEX)

Nas palavras de Rodrigo Sánches Ríos ${ }^{209}$, citando Fernando Perez Royo, a raiz do instituto da extinção da punibilidade pelo pagamento do crédito tributário encontra-se no ordenamento jurídico alemão. Referido instituto, naquele país, é denominado autodenúncia liberadora da pena.

Afirma César de Faria Júnior ${ }^{210}$, com esteio em Heleno Cláudio Fragoso, que $a$ legislação pátria, ao longo dos anos, tem, sucessivamente, permitido o recolhimento do

\footnotetext{
${ }^{207}$ DOTTI, René Ariel. Teoria Geral da Punibilidade. Revista CEJ. Brasília. v. 3. n. 7. p. 24-31. abr. 1999.

${ }^{208}$ PASCHOAL, Janaina Conceição. Direito Penal. Parte Geral. Barueri: Manole, 2003.

${ }^{209}$ RíOS, Rodrigo Sánches. Das Causas de Extinção da Punibilidade nos Delitos Econômicos. São Paulo: RT, 2003. p. 138.

${ }^{210}$ FARIA JÚNIOR, César de. Crime Previdenciário. Revista Brasileira de Ciências Criminais. São Paulo, v. 3, n. 11, p. 113-7, jul./set. 1995.
} 
débito em atraso, e, em todas as vezes que isso ocorreu, a jurisprudência, pacificamente, entendeu ter tornado o fato ora em exame penalmente impunível.

Como antecedente no Direito Penal brasileiro pode-se citar o artigo 34 da Lei $n^{\circ}$ 9.249/95, que estabelecia:

Extingue-se a punibilidade dos crimes definidos na Lei $\mathrm{n}^{\circ} 8.137$, de 27 de dezembro de 1990 , e na Lei $n^{\circ} 4.729$, de 14 de julho de 1965 , quando o agente promover o pagamento do tributo ou contribuição social, inclusive acessórios, antes do recebimento da denúncia.

Tal instituto também era aplicado aos crimes previdenciários do artigo 95 da Lei $\mathrm{n}^{\circ}$ 8.212/91, antecessores dos delitos previdenciários que, atualmente, estão contemplados nos artigos 168-A e 337-A do Código Penal.

A Lei $n^{\circ}$ 9.964/00, instituiu o Programa de Recuperação Fiscal - REFIS ${ }^{211}$, estabelecendo a extinção da punibilidade dos delitos previstos no artigo 95 da Lei ${ }^{\circ}$ 8.212/91, que criminalizava, à época, uma série de condutas lesivas à arrecadação da seguridade social, entre elas, a de apropriação indébita previdenciária (artigo 95, "d") ${ }^{212} \mathrm{e}$ de sonegação de contribuição previdenciária (art. 95, "a", "b" e "c"). Confira-se:

Art. 15. É suspensa a pretensão punitiva do Estado, referente aos crimes previstos nos arts. $1^{\circ}$ e $2^{\circ}$ da Lei $n^{\circ} 8.137$, de 27 de dezembro de 1990 , e no art. 95 da Lei $n^{\circ} 8.212$, de 24 de julho de 1991, durante o período em que a pessoa jurídica relacionada com o agente dos aludidos crimes estiver incluída no Refis, desde que a inclusão no referido Programa tenha ocorrido antes do recebimento da denúncia criminal.

$\S 1^{\circ}$ A prescrição criminal não corre durante o período de suspensão da pretensão punitiva.

$\S 2^{\circ}(\ldots)$

$\S 3^{\circ}$ Extingue-se a punibilidade dos crimes referidos neste artigo quando a pessoa jurídica relacionada com o agente efetuar o pagamento integral dos débitos oriundos de tributos e contribuições sociais, inclusive acessórios, que tiverem sido objeto de concessão de parcelamento antes do recebimento da denúncia criminal.

De se ressaltar, nos trechos transcritos, que a inclusão no programa de parcelamento dever-se-ia dar antes do oferecimento da denúncia criminal. Merece ser

${ }^{211}$ Art. $1^{o}$ : É instituído o Programa de Recuperação Fiscal - Refis, destinado a promover a regularização de créditos da União, decorrentes de débitos de pessoas jurídicas, relativos a tributos e contribuições, administrados pela Secretaria da Receita Federal e pelo Instituto Nacional do Seguro Social - INSS, com vencimento até 29 de fevereiro de 2000, constituídos ou não, inscritos ou não em dívida ativa, ajuizados ou a ajuizar, com exigibilidade suspensa ou não, inclusive os decorrentes de falta de recolhimento de valores retidos.

${ }^{212}$ Sobre a evolução do tipo penal, ver capítulo 3.2.1.1. 
destacado que referida lei determinou a suspensão da pretensão punitiva estatal durante o prazo do parcelamento. Há benefício para o contribuinte-acusado, pois desde o momento de adesão ao programa de recuperação fiscal fica obstada a persecução penal. Por outro lado, equilibrando a equação, fica suspenso o prazo prescricional do crime, o que parece ser medida acertada, haja vista a possibilidade de o agente deixar de cumprir com os pagamentos estabelecidos, frustrando a arrecadação dos valores. Todavia, a extinção da punibilidade é fenômeno restrito à adesão ao programa de parcelamento, e só tem lugar antes de oferecida a denúncia criminal.

Juntamente com as normas que descrevem as condutas típicas de apropriação indébita previdenciária e sonegação de contribuição previdenciária, a Lei no 9.983/00²13 trouxe, para o Código Penal, causas de extinção da punibilidade relativas aos artigos 168$\mathrm{A}\left(\S 2^{\mathrm{o} 214}\right)$ e $337-\mathrm{A}\left(\S 1^{\mathrm{o} 215}\right)$.

Destaque-se, de início, que referidos dispositivos do Código Penal apresentam grande similitude, mas não identidade. É que o tratamento dado à apropriação indébita previdenciária é mais rígido, pois exige que o agente efetue o pagamento para que alcance a extinção da punibilidade. Já no crime de sonegação de contribuição previdenciária basta declarar e confessar os valores devidos, sem necessidade de seu pagamento. Esse tratamento desigual não ficou indene a críticas: denota-se, obviamente, a incongruência do legislador na elaboração dos tipos penais, acentuando o tratamento diferenciado para condutas da mesma família delitiva ${ }^{216}$.

\footnotetext{
${ }^{213}$ Em sucinto estudo acerca da extinção da punibilidade, publicado logo após a edição do texto legal afirmou Heloisa Estellita Salomão: essa brevíssima apresentação, que se restringe a um único aspecto da nova disciplina, já evidencia a falta de técnica do legislador e o seu total despreparo no trato da matéria. Trata-se claramente de intervenção penal de cunho estritamente simbólico e com fins de mero aumento da arrecadação tributária, realizada à revelia dos princípios da intervenção mínima, da proporcionalidade e da isonomia (...) (SALOMÃO, Heloisa Estellita. Extinção da punibilidade pelo pagamento nos crimes tributários e previdenciários após o advento da lei 9.983/00. Revista Síntese de Direito Penal e Processual Penal. Porto Alegre. v. 2, n. 8, p. 63-5, jun./jul. 2001).

${ }^{214}$ É extinta a punibilidade se o agente, espontaneamente, declara, confessa e efetua o pagamento das contribuições, importâncias ou valores e presta as informações devidas à previdência social, na forma definida em lei ou regulamento, antes do início da ação fiscal.

${ }^{215}$ É extinta a punibilidade se o agente, espontaneamente, declara e confessa as contribuições, importâncias ou valores e presta as informações devidas à previdência social, na forma definida em lei ou regulamento, antes do início da ação fiscal.

${ }^{216}$ RÍOS, Rodrigo Sánches. Das Causas de Extinção da Punibilidade nos Delitos Econômicos. São Paulo: RT, 2003. p. 163.
} 
No que concerne à comparação do texto da Lei $n^{\circ}$ 9.964/00 com aquele que passou a ter vigência após as alterações do Código Penal, introduzidas pela Lei $\mathrm{n}^{\mathbf{o}}$ 9.983/00, faz-se relevantes algumas observações.

Pode-se concluir ter havido agravamento da situação do acusado, uma vez que a norma anterior previa a possibilidade de adesão ao sistema, com conseqüente probabilidade da extinção da punibilidade, até antes do oferecimento da denúncia criminal. A lei posterior só admite a extinção da punibilidade antes do início da ação fiscal, o que levou a intensa discussão doutrinária, a fim de se delimitar o exato sentido de tal expressão $^{217}$. Entretanto, se tomada a norma anterior (Lei n $\left.{ }^{\circ} 9.964 / 00\right)$, especificamente no que tange ao crime de sonegação de contribuição previdenciária, há que se notar, por outro aspecto, ter se tornado menos gravosa a situação do acusado: é que pelo texto da Lei $\mathrm{n}^{\mathrm{o}}$ 9.964/00 era necessário o pagamento integral dos valores e, com as alterações do Código Penal, basta declarar e confessar o débito.

A Lei $\mathrm{n}^{\mathrm{o}} 10.684^{218}$, de 30 de maio de 2003 (REFIS II ou PAES) que teve origem na conversão da Medida Provisória $n^{\circ}$ 107/03, tratou da suspensão da pretensão punitiva e da extinção da punibilidade em seu artigo $9^{\circ}$ :

\begin{abstract}
Art. $9^{\circ}$. É suspensa a pretensão punitiva do Estado, referente aos crimes previstos nos arts. $1^{\circ}$ e $2^{\circ}$ da Lei no 8.137, de 27 de dezembro de 1990, e nos arts. 168A e 337A do Decreto-Lei no 2.848, de 7 de dezembro de 1940 - Código Penal, durante o período em que a pessoa jurídica relacionada com o agente dos aludidos crimes estiver incluída no regime de parcelamento.

$\S 1^{\circ}$ A prescrição criminal não corre durante o período de suspensão da pretensão punitiva.

$\S 2^{\circ}$ Extingue-se a punibilidade dos crimes referidos neste artigo quando a pessoa jurídica relacionada com o agente efetuar o pagamento integral dos débitos oriundos de tributos e contribuições sociais, inclusive acessórios.
\end{abstract}

A nova regulamentação de recuperação fiscal possibilitou o parcelamento de quaisquer contribuições, ou seja: ficam abrangidos pelo programa tanto os valores relativos à contribuição do empregado (que se retidos e não repassados passam a constituir o crime de apropriação indébita previdenciária) como também os valores referentes às obrigações do empregador (as quais não adimplidas caracterizam o crime de sonegação de

\footnotetext{
217 A esse respeito, com exposição minudente das correntes que se estabeleceram, consultar SALOMÃO, Heloisa Estellita. Novos Crimes Previdenciários - Lei no 9.983/00, de 14 de julho de 2000: Primeiras Impressões. Revista Dialética do Direito Tributário. São Paulo, n. 64, p. 70-90, jan. 2001.

${ }^{218}$ Altera a legislação tributária, dispõe sobre parcelamento de débitos junto à Secretaria da Receita Federal, à Procuradoria-Geral da Fazenda Nacional e ao Instituto Nacional do Seguro Social e dá outras providências.
} 
contribuição previdenciária). Não há qualquer menção ao momento do pagamento e o estágio já alcançado pela persecução criminal, com o que se passou a entender que o pagamento do débito, a qualquer tempo, acarreta a extinção da punibilidade.

A legislação, em seu $\S 2^{\circ}$, trouxe para além dos programas de recuperação fiscal a disciplina da extinção da punibilidade, flexibilizando, principalmente no que condiz com o elemento temporal, a normatização acerca do assunto. Assim, para qualquer dos crimes contra a ordem tributária dos artigos $1^{\circ}$ e $2^{\circ}$ da Lei $n^{\circ} 8.137 / 90$, bem como para os crimes dos artigos 168-A e 337-A do Código Penal, extingue-se a punibilidade (...) quando a pessoa jurídica relacionada com o agente efetuar o pagamento integral dos débitos oriundos de tributos e contribuições sociais, inclusive acessórios.

Em 29 de junho de 2006, pela Medida Provisória $n^{\text {o }} 303^{219}$, ficou instituído novo programa de recuperação fiscal, que passou a ser chamado REFIS III ou PAEX ${ }^{220}$. Confira-se seu artigo $1^{\circ}$ :

os débitos de pessoas jurídicas junto à Secretaria da Receita Federal - SRF, à Procuradoria-Geral da Fazenda Nacional - PGFN e ao Instituto Nacional do Seguro Social - INSS, com vencimento até 28 de fevereiro de 2003, poderão ser, excepcionalmente, parcelados em até cento e trinta prestações mensais e sucessivas, na forma e condições previstas nesta Medida Provisória.

O novo programa procurou abarcar todo e qualquer débito fiscal federal, constituído ou não, inscrito ou não em dívida ativa da União ou do Instituto Nacional do Seguro Social (INSS). Admitiu, sob suas regras, o parcelamento de débitos que estavam sendo discutidos judicialmente em ação proposta pelo sujeito tributário passivo ou em fase de execução fiscal já ajuizada. Englobou, ainda, débitos que haviam sido objeto de parcelamento anterior, não integralmente quitado, ainda que cancelado por falta de pagamento $^{221}$.

Oportunizou-se, assim, uma acolhida aos devedores de tributos, entre eles os autores de crimes de sonegação de contribuição previdenciária. Não foram admitidos ao referido parcelamento, todavia, os débitos relativos à apropriação indébita previdenciária,

\footnotetext{
${ }^{219}$ Dispõe sobre parcelamento de débitos junto à Secretaria da Receita Federal, à Procuradoria-Geral da Fazenda Nacional e ao Instituto Nacional do Seguro Social nas condições que especifica e altera a legislação tributária federal.

${ }^{220}$ Parcelamento excepcional.

${ }^{221}$ Conforme $\S 1^{\circ}$ do artigo $1^{\circ}$.
} 
por força do artigo $2^{\circ}$, I, da referida Medida Provisória ${ }^{222}$, em vista do desconto se operar antes do obrigatório repasse ao órgão de arrecadação. Contudo, não houve qualquer menção aos efeitos penais do parcelamento, nem ao artigo $9^{\circ}$ da Lei $n^{\circ} 10.684 / 03$. Assevera, assim, Heloisa Estellita ${ }^{223}$ :

(...) em conformidade com o entendimento consagrado no Supremo Tribunal Federal, trata-se tão-somente de nova modalidade de parcelamento de débitos tributários federais, mantida a disciplina prevista no artigo $9^{\circ}$ da Lei $n^{\circ} 10.864 / 03$ quanto aos efeitos penais; isto é, deferido o parcelamento suspende-se a pretensão punitiva e a prescrição, pago o tributo (de uma vez só ou como quitação do parcelamento), extinta estará a punibilidade.

No que pertine à Medida Provisória n 303/06, cabe ressaltar que não foi convertida em lei, conforme determina o artigo $62, \S 3^{\circ}$, da Constituição da República ${ }^{224}$, nem teve suas relações jurídicas disciplinadas, restando, portanto, conservados os efeitos dos acontecimentos por ela regidos ${ }^{225}$. Em 31 de outubro de 2006, pelo ato $\mathrm{n}^{\mathrm{o}} 57$ do Presidente do Congresso Nacional, foi comunicada a perda de vigência da Medida Provisória $^{226}$.

Sendo assim, a suspensão da pretensão punitiva e da prescrição em matéria de delitos contra a arrecadação da seguridade social, bem como a extinção da punibilidade pelo pagamento do débito continuam regidas pelo artigo $9^{\circ}$ da Lei ${ }^{\circ} 10.684 / 03$.

A extinção da punibilidade pelo pagamento, hoje, em relação aos crimes fiscais e também em relação aos delitos previdenciários, funciona como uma válvula de escape do

${ }^{222} \mathrm{O}$ parcelamento de que trata o art. $1^{\circ}$ não se aplica a débitos:

I- relativos a impostos e contribuições retidos na fonte ou descontados de terceiros e não recolhidos à Fazenda Nacional ou ao INSS;

(...)

${ }^{223}$ ESTELLITA, Heloisa. O parcelamento previsto na MP 303/06 e a punibilidade nos crimes tributários. Boletim IBCCRIM, São Paulo, ano 14, n.165, p. 14, ago. 2006.

$224 \S 3^{\circ}$. As medidas provisórias, ressalvado o disposto nos $\S \S 11$ e 12 perderão eficácia, desde a edição, se não forem convertidas em lei no prazo de sessenta dias, prorrogável, nos termos do $\S 7^{\circ}$, uma vez por igual período, devendo o Congresso Nacional disciplinar, por decreto legislativo, as relações jurídicas delas decorrentes.

$225 \S 11$. Não editado o decreto legislativo a que se refere o $\S 3^{\circ}$ até sessenta dias após a rejeição ou perda de eficácia de medida provisória, as relações jurídicas constituídas e decorrentes de atos praticados durante sua vigência conservar-se-ão por ela regidas.

${ }^{226}$ O Presidente da mesa do Congresso Nacional, nos termos do $\S$ único do art. 14 da Resolução $n^{\circ} 1$, de 2002-CN, faz saber que a Medida Provisória $n^{\circ}$ 303, de 29 de junho de 2006, que "Dispõe sobre parcelamento de débitos junto à Secretaria da Receita Federal, à Procuradoria-Geral da Fazenda Nacional e ao Instituto Nacional do Seguro Social nas condições que especifica e altera a legislação tributária federal”, teve seu prazo de vigência encerrado no dia 27 de outubro do corrente ano. 
sistema. Fica instituída por intermédio da extinção da punibilidade pelo pagamento verdadeira exclusão de pena, extensível a todos os agentes, indistintamente. É por isso que se afirma ser tal instituto um tortuoso atalho para a descriminalização.

\title{
5.3 Direito Penal, Law and Economics e eficiência
}

A Emenda Constitucional no 19, de 5 de junho de 1998, introduziu no texto do artigo 37 da Constituição da República a eficiência como um dos princípios da Administração Pública, muito embora desde muito alguns já a apontassem como princípio implícito $^{227}$.

Maria Sylvia Zanella Di Pietro assevera que o princípio da eficiência impõe ao agente público um modo de atuar que produza resultados favoráveis à consecução dos fins que cabem ao Estado alcançar ${ }^{228}$. Nas palavras de Márcio Fernando Elias Rosa, o princípio em questão ${ }^{229}$

\begin{abstract}
abarca dois entendimentos possíveis: tange ao agente público, que não pode atuar amadoristicamente, devendo buscar a consecução do melhor resultado possível, como também diz respeito à forma de organização da Administração Pública, que deve atentar para os padrões modernos de gestão ou administração, vencendo o peso burocrático, atualizando-se e modernizando-se.
\end{abstract}

A Análise Econômica do Direito funda-se no seguinte raciocínio: o comportamento dos agentes econômicos é impactado pelo arcabouço normativo. Portanto o Direito, ao normatizar e prescrever condutas, deve se preocupar com as consequiências que trará aos temas que pretende regular, sempre buscando potencializar a eficiência nas relações humanas. Assim, o Direito influencia e é influenciado pela Economia (... $)^{230}$. Nesta ordem de idéias até os delinqüentes, quando optam e decidem pela prática criminosa,

${ }^{227}$ Conferir citação de Sérgio Andréa Ferreira, referido em MORAES, Alexandre de. Direito Constitucional. 16. ed. São Paulo: Atlas, 2004. p. 317.

${ }^{228}$ DI PIETRO, Maria Sylvia Zanella. Direito Administrativo. 10. ed. São Paulo: Atlas, 1999. p. 73.

${ }^{229}$ ROSA, Márcio Fernando Elias. Direito Administrativo. 9. ed. São Paulo: Saraiva, 2007. p. 17.

${ }^{230}$ ZILBERSTAJN, Decio; STAJN, Rachel. Análise Econômica do Direito e das Organizações. Direito \& Economia. Rio de Janeiro: Elsevier, 2005. p. 3. 
ou quando a abandonam, também obedecem a considerações de eficiência, isso é, calculam os custos e as vantagens que cada ação lhes proporciona ${ }^{231}$.

Do mesmo modo, Günther Jakobs no texto A ciência do Direito Penal ante as exigências da atualidade anota ser uma característica da sociedade contemporânea o predomínio da economia. Neste diapasão, faz o autor alusão a um atributo da sociedade de hoje que tem grande relação com a lógica do individualismo, a competitividade: êxito econômico se decide no mercado, isto é, em um mercado de competição, no qual sempre se considera mais bem preparado aquele que aproveita todas as oportunidades para apresentar suas ofertas de modo mais favorável (...) ${ }^{232}$.

Richard Allen Posner, conceitua o princípio da eficiência como a maximização da riqueza. Defende, ainda, o magistrado norte-americano, que o homem, antes de um ser moral, é um ser econômico, caracterizando-se como um maximizador racional de seu auto-interesse ${ }^{233}$.

A ingerência é recíproca, pois se os agentes econômicos têm o sistema normativo como um dado a ser levado em consideração para a tomada de decisão - e assim o Direito influencia a Economia - os operadores do Direito, principalmente legisladores e juízes, precisam ter consciência de que suas opções trazem consequiências econômicas e devem tomar tais decisões pautados, também, pelos incrementos sociais que promoverão. Ou que não promoverão.

A Análise Econômica do Direito persegue a eficiência das relações humanas. $\mathrm{O}$ Direito distribuído será tanto melhor quanto mais eficiente for o resultado por ele produzido. Com relação, por exemplo, ao Direito Concorrencial, defende a Análise Econômica do Direito que a melhor forma de distribuição de riqueza é dada pelo mercado, já que ele é o palco mais democrático que existe. Para que o mercado concretize todas as suas possibilidades de distribuir a riqueza deve ter como premissa um alto índice de concorrência. A perfeição do funcionamento do mercado, neste diapasão, seria diretamente proporcional ao nível de concorrência que ele encerra. Assim, o Estado tem o papel

\footnotetext{
${ }^{231}$ SÁNCHES, Jesus Maria Silva. Eficiência e Direito Penal. trad. Mauricio Ribeiro Lopes. Barueri: Manole, 2004. p. 11.

${ }^{232}$ JAKOBS, Günther. Ciência do Direito. Coleção Estudos de Direito Penal. Barueri: Manole, 2003. p. 47.

${ }^{233}$ Citado por DIAS, Jefferson Aparecido. Crime de Apropriação Indébita Previdenciária. CP, art. 168-A, $\S$ $1^{o}$, inc. I. 2. ed. Curitiba: Juruá, 2007. p. 26-7.
} 
fundamental de garantir as instituições, dar-lhes segurança, criando as condições para o funcionamento dos mercados e outros arranjos institucionais ${ }^{234}$.

Talvez a maior objeção levantada contra a Análise Econômica do Direito seja a incompatibilidade de fundamento entre as duas ciências, quais sejam, a econômica e a jurídica.

Nesta ordem de idéias, a ciência econômica teria por objeto o estudo da escassez de meios materiais e, como fim, a maximização da utilização dos recursos proporcionados por tais meios. O método de estudo da Economia, basicamente, é o empírico, pois suas verdades seriam construídas através de modelos práticos, hauridos da realidade. É o conhecimento produzido pela Economia daqueles que se dobra aos fatos, a eles se amolda, já que sobre eles é construído. A economia estuda e enuncia a realidade. Trabalha com o ser. Faz uso de modelos teóricos, que são tanto melhores quanto mais se consegue demonstrá-los com dados reais.

Por sua vez, o Direito cuida do dever-ser. Muito embora seja inegável a interação entre o mundo dos fatos e o Direito, claro é que essa interação é muito menos intensa do que a verificada entre a Economia e a realidade. O Direito não se conforma aos fatos. O reiterado descumprimento de uma norma não tem o condão de extrair sua carga coativa. Nota-se, portanto, uma real e primeira questão, que aparta Economia e Direito: este prescreve; aquela descreve.

Sob mais um aspecto o Direito se diferencia da Economia: a missão. Cumpre ao Direito resolver conflitos, pacificar a sociedade, pautado por princípios de ética, justiça e igualdade. À Economia cabe racionalizar os meios de produção, potencializar a geração de riquezas, indicar eventuais caminhos que apresentem melhor produtividade. Em uma palavra: a teoria econômica busca a eficiência.

Pode ainda ser estabelecida outra marcante distinção: a falta de segurança do caminho indicado pelo Direito, já que construído sobre bases fluidas como justiça, ética, versus a racionalidade - quase puramente matemática - da Economia, que se prende a parâmetros exatos, concretos.

${ }^{234}$ ZILBERSTAJN, Decio; STAJN, Rachel. Análise Econômica do Direito e das Organizações. Direito \& Economia. Rio de Janeiro: Elsevier, 2005. p. 6. 
O fato indaga a norma, e daí podem surgir, e efetivamente surgem, várias respostas corretas. Não é casualmente que a fim de apurar a verdade, de reconstruir os acontecimentos e de aplicar a justiça ao caso concreto, tenha se desenvolvido um ramo específico do Direito, autônomo, portanto: o Direito Processual. O Direito do processo é uma meta-estrutura, já que é composto de normas que se destinam à aplicação de outras normas. É um Direito que busca a efetivação de outro Direito. São tão complexas e admitem tantas variáveis as soluções jurídicas que o próprio ordenamento cuidou de regulamentar o caminho pelo qual se chega à solução-resposta.

Relevante questionamento se coloca: podem ciências tão distintas, que desempenham distintas funções, utilizando-se de distintos métodos, serem estudadas ao mesmo tempo, sob os mesmos olhos, ou melhor: serve ao Direito o método econômico de análise das relações sociais?

Questão interessante se coloca quando se analisa a recomposição da arrecadação da seguridade social pelo pagamento, o que leva à extinção da punibilidade do agente. Atualmente rege essa matéria o artigo $9^{\circ}$ da Lei $n^{\circ} 10.684$ de 30 de maio de $2003^{235}$.

Nos exatos termos do texto legal, o acusado de apropriação indébita previdenciária ou de sonegação de contribuição previdenciária em processo criminal tem opção de liquidar a dívida apurada e furtar-se à aplicação da lei penal. Importante notar que o autor de pequeno furto não encontra nos diplomas normativos semelhante possibilidade.

Duas razões justificariam a exclusão da punibilidade pelo pagamento: um fim político-fiscal de escopo arrecadatório, e os fins jurídico-penais (voluntariedade e reparação): na finalidade político-fiscal resulta evidente a necessidade de uma maior arrecadação das contribuições por intermédio da regularização extemporânea, com conseqüentes reflexos na esfera penal (...). Em relação à justificativa jurídico-penal, a pena se faria desnecessária, uma vez que já estaria atingido seu escopo de prevenção geral e especial $^{236}$.

\footnotetext{
${ }^{235}$ Confira-se capítulo 5.2.

${ }^{236}$ RÍOS, Rodrigo Sánches. Das Causas de Extinção da Punibilidade nos Delitos Econômicos. São Paulo: RT, 2003. p. 161.
} 
Nota-se, assim, o caráter meramente arrecadatório da norma penal, que ameaça com a possibilidade de condenação criminal o indivíduo acusado da prática de crime contra a arrecadação para a seguridade social. Verifica-se, portanto, que tal norma atua, exclusivamente, para incentivar o recolhimento do valor que se imputa apropriado ou sonegado, abandonado o pressuposto da justiça que deve reger, tanto quanto possível, a edição de normas jurídicas. Fica latente a influência da Law and Economics, já que a extinção da punibilidade será acompanhada do recolhimento aos cofres públicos dos valores indevidamente apropriados; acarretará, ainda, o fim do processo, e a diminuição dos custos gerados com as demandas judiciais. Ou seja: maior eficiência - aos olhos da Economia.

Contudo, há que se agregar à discussão significativo ponto de vista. Jesus Leguina Villa, citado por Maria Sylvia Zanella Di Pietro assevera que a eficácia que a Constituição exige da administração não se deve confundir com a eficiência das organizações privadas nem é, tampouco, um valor absoluto diante dos demais ${ }^{237}$.

A eficiência (da Economia), pois, pode e deve se dobrar à ética, justiça e igualdade (do Direito). Com a adoção da extinção da punibilidade pelo pagamento, não se duvida que aos cofres públicos, num primeiro momento, mais recursos são carreados, pois quem se apropria ou sonega contribuição previdenciária, muitas vezes, prefere pagar para se ver longe das varas criminais.

Resta saber se o mecanismo de extinção da punibilidade pelo pagamento não esvaziará a contribuição voluntária, já que essa é desestimulada em face da possibilidade de exclusão da pena pelo pagamento no curso do processo. Resta saber ainda se, de forma ineficaz, a única forma eficaz de recolhimento passará a ser a ameaça da pena privativa de liberdade, a demonstrar que Direito e Economia, em algumas searas, não devem se misturar.

${ }^{237}$ DI PIETRO, Maria Sylvia Zanella. Direito Administrativo. 10. ed. São Paulo: Atlas, 1999. p. 74. 


\title{
6 ADEQUAÇÃO E NECESSIDADE DA TUTELA PENAL
}

\subsection{O Direito (Penal) como instrumento de controle social}

O Direito Penal se diferencia dos demais ramos do Direito pela qualidade de sua sanção. Todos os subsistemas legais emprestam coatividade aos seus mandamentos por meio da sanção. Diz o Direito Civil, por exemplo, que o casamento é nulo (sanção) se não realizado de acordo com as formalidades e ritos prescritos ${ }^{238}$. No Direito do Trabalho, recebe multa (sanção) a empresa que mantiver empregado não registrado ${ }^{239}$. No Código Eleitoral, Lei $n^{o} 4.737 / 65$, há previsão de multa (sanção) para o eleitor faltoso que não justificar sua ausência ${ }^{240}$.

A excepcional característica do Direito Penal, que o aparta dos demais ramos do Direito, é a qualidade de sua sanção, ou seja, a imposição de uma pena, na maioria das vezes, privativa de liberdade. Ao tecer comentários sobre o conceito de Direito Penal, Giulio Battaglini prefere dar destaque ao caráter que diferencia nosso objeto de estudo dos demais ramos do Direito, nos seguintes termos:

\begin{abstract}
a sanção surge como esteio do preceito jurídico, consistindo, como consiste, em reação de caráter aflitivo, que toma o nome técnico de "pena". Visa ela, mediante a ameaça, à garantia da observância do preceito, através da influência que lhe é peculiar sobre a vontade do destinatário (...). É o elemento sanção que possibilita estabelecer formalmente a distinção entre ilícito penal e os demais ilícitos jurídicos $^{241}$.
\end{abstract}

Portanto, todo o sistema penal se organiza para decidir quem merece a imputação da sanção, no caso, a pena. Seja o Direito Penal, estabelecendo conceitos e delimitando a tipicidade dos fatos, seja o Direito Processual Penal, regulamentando o procedimento de apuração, verdadeiro calvário a ser trilhado pelo acusado, seja ainda a Lei de Execução Penal, traçando as diretrizes para a concretização do encarceramento: os diplomas normativos, de forma indecomponível, estão voltados a dizer, no caso concreto,

\footnotetext{
${ }^{238} \mathrm{O}$ casamento é nulo nas hipóteses do artigo 1.548 e anulável nas do artigo 1.550 do Código Civil.

${ }^{239}$ Artigo 47 da Consolidação das Leis do Trabalho (CLT).

${ }^{240}$ Art. $7^{\circ}$. O eleitor que deixar de votar e não se justificar perante o juiz eleitoral até 30 (trinta) dias após a realização da eleição, incorrerá na multa de 3 (três) a 10 (dez) por cento sobre o salário-mínimo da região, imposta pelo juiz eleitoral e cobrada na forma prevista no art. 367.

${ }^{241}$ BATTAGLINI, Giulio. Direito Penal: parte geral. trad. Paulo José da Costa Jr. e Arminda Bergamini Miotto. São Paulo: Saraiva, 1973. p. 7.
} 
quem terá privação da liberdade, e até quando. Para tanto são utilizados critérios, que apartam, grosso modo, os indivíduos em dois grandes grupos: os libertos e os encarcerados.

O homem é produto de seu meio. Nas palavras de Miguel Reale Júnior ${ }^{242}$,

as crenças e os valores, que constituem as diretrizes informadoras do ordenamento da vida social e do nosso modo de ser comum, são comunicados às crianças, sendo aos poucos e imperceptivelmente adquiridos, assim como os hábitos e costumes cotidianos, que refletem, também, as visões da vida e os valores predominantes no meio social em que se desenvolvem.

O processo de aculturação do ser humano é fenômeno conhecido bem estudado. Por meio do contato com familiares e outras pessoas o homem aplica ao substrato biológico, bruto, as lições do cotidiano, e pouco por vez vai se formando. Assim como aprende a ler, a escrever, a utilizar-se do computador, o homem aprende a conviver com os demais de sua espécie. Aprende a respeitar os idosos, aprende a portar-se socialmente e desenvolve, de acordo com os estímulos que recebe, suas aptidões e qualidades $^{243}$.

Desenvolve, também, hábitos contrários ao saudável transcorrer da vida social. Verifica-se, desde logo, um paradoxo: se o homem é produto da sociedade, como, então, pode ele desenvolver condutas que atentem contra o bom andamento da vida social? Já que é um ser gregário, por natureza, não seria uma contradição inexplicável a realização de atos que colocam em risco a própria sociedade? As imagens são antigas, mas podem ser lembradas para ilustrar o quanto se pretende demonstrar: o homem, quando se desvia do comportamento que dele se espera age como o escorpião, que destila veneno sobre o próprio corpo, ou como a cobra, que ataca o próprio rabo.

O fato é que, muitas vezes, o processo de aculturação não é completo, mas fragmentário. Essa influência que o meio conglobante exerce sobre o homem não tem a capacidade de impedir que ele desempenhe condutas contrárias às regras sociais. O entorno influencia o ser humano e, diuturnamente, no relacionamento entre dois ou mais indivíduos, mensagens são trocadas. Mensagens de felicitação por um comportamento

\footnotetext{
${ }^{242}$ REALE JÚNIOR, Miguel. Teoria do Delito. 2. ed. São Paulo: RT, 2000. p. 16.

${ }^{243}$ Podemos apresentar o processo de aprendizagem moral como o alargamento inteligente e a limitação recíproca do mundo social, que ainda não se recompôs suficientemente, em um caso de conflito dado (HABERMAS, Jürgen. Agir comunicativo e razão destrancentralizada. Rio de Janeiro: Tempo Brasileiro, 2002. p. 64).
} 
aprovado socialmente (por exemplo, a realização de um trabalho benemérito), ou mensagens de repúdio, quando são desempenhados papéis contrários aos interesses sociais (por exemplo, o abandono financeiro de filhos menores ou o excessivo e reiterado consumo de substâncias entorpecentes).

Portanto, os homens se comunicam. E é através da comunicação que serão formados, avaliados, felicitados ou repreendidos. Cabe, portanto, retomar a indagação: se o homem nasce, cresce e é formado em sociedade, e sabe que para a manutenção dessa sociedade é imperioso que se observem determinadas restrições comportamentais, por que, muitas vezes, desempenha papéis contrários aos interesses sociais? Duas são as respostas possíveis: a primeira, admite que o processo de aculturação não é completo, ou seja, o caráter de contrariedade de alguns atos residiria na falta de introjeção dos valores sociais. A ausência da prévia informação impede a conformação do comportamento (tomem-se, verbi gratia, três pessoas que marcam determinado encontro, em determinado local. Imagine-se que após o apontamento do local do encontro, duas dessas pessoas travem uma outra conversa, da qual não participa o terceiro indivíduo. Durante este colóquio resolvem alterar o local do encontro, e tal informação não chega ao conhecimento da terceira pessoa. Por óbvio que esta terceira pessoa falhará). Mas pode ser admitida outra resposta válida: muito embora tenha sido recepcionada pelo indivíduo a mensagem que determinava a escolha socialmente correta, opta-se pela transgressão ao comportamento pré-estabelecido: uma ação contrária à vida social.

É de se notar, primeiramente, que a escolha de um comportamento indesejável do ponto de vista social não aponta, na maioria das vezes, para alguma anomalia psíquica ou distúrbio fisiológico. Desde a superação da Escola Positiva abandonou-se a idéia da morbidez que, para essa doutrina, era inerente a todo desvio comportamental. Portanto, a negação do padrão de comportamento convive perfeitamente com a higidez mental e, com bastante tranqüilidade, pode-se admiti-la como elemento integrante da vida social. A morte faz parte da vida, assim como as condutas contrárias ao interesse comunitário são aspectos da vida comum. A opção que se toma em desfavor da sociedade é, por conseguinte, inerente à própria dinâmica social.

A maior evidência de que os comportamentos contrários às expectativas sociais são comuns e fazem parte do convívio humano faz-se com a simples leitura da Parte Especial do Código Penal: ali estão relacionadas centenas de condutas contrárias ao 
saudável convívio gregário, condutas essas que se repetem com tamanha insistência que puderam ser descritas e individualizadas de forma sistemática ${ }^{244}$.

Seguindo essa linha de raciocínio, pode-se afirmar, com Santiago Mir Puig ${ }^{245}$, que

o Direito penal constituiu um dos meios de controle social existentes na sociedade atual (...) Como todo meio de controle social, o Direito tende a evitar determinados comportamentos sociais considerados indesejáveis, recorrendo, para isso, à ameaça de imposição de distintas sanções, caso tais condutas sejam realizadas (...)

A seguridade social no Brasil, o fato é incontestável, há muito perdeu a capacidade de suprir as necessidades dos indivíduos. Alguns certamente aludirão que em tempo nenhum nosso sistema de seguridade social foi capaz de atender dignamente aos reclamos da população. Que o diga o major Bustamante, personagem de Lima Barreto que no Triste Fim de Policarpo Quaresma procura, à exaustão, conhecer a legislação que regeria sua aposentadoria. O cidadão não se sente protegido pelo sistema de seguridade social. Assim como a obtenção de um diploma de nível superior não conduz obrigatoriamente ao sucesso profissional, a contribuição mensal à previdência não leva ninguém a acreditar que receberá suporte em momentos dificultosos da vida.

Somem-se a esta constatação as inúmeras alterações das regras que procuram organizar o sistema contributivo e os indecifráveis cálculos aritméticos utilizados para o deferimento dos benefícios. Mas não é só: a demora para a concessão dos auxílios e as constantes greves dos servidores ligados aos órgãos públicos responsáveis pela análise dos pedidos tornam o sistema desmerecedor da confiança dos indivíduos que dele dependem. Assim como também o fazem desacreditado as incontáveis notícias de fraudes a que a seguridade social, costumeiramente, se vê exposta. A corroborar o quanto se alega basta verificar a expansão desenfreada dos planos particulares de saúde ${ }^{246}$ e previdência ${ }^{247}$, reflexo do caos instalado no aparelho público de seguridade social ${ }^{248}$.

\footnotetext{
${ }^{244}$ Por exemplo, é tão esperado que um homem destrua a vida de outro que o Direito Penal se antecipa e cria a figura do homicídio.

${ }^{245}$ MIR PUIG, Santiago. Direito Penal. Fundamentos e Teoria do Delito. trad. Cláudia Viana Garcia e José Carlos Nobre Porciúncula Neto. São Paulo: RT, 2007. p. 33.

${ }^{246}$ A Constituição da República (artigo 199) prescreve ser a assistência à saúde livre à iniciativa privada e, ainda, que as instituições privadas poderão participar de forma complementar do sistema único de saúde, segundo diretrizes deste, mediante contrato de direito público ou convênio, tendo preferência as entidades filantrópicas e as sem fins lucrativos. Entretanto, veda a destinação de recursos públicos para auxílios ou
} 
A Associação dos Magistrados do Brasil (AMB) realiza pesquisa anual sobre a imagem das instituições públicas brasileiras ${ }^{249}$. Em 2007 os dados foram obtidos junto a mais de duas mil pessoas, igualmente divididas pelos dois sexos, maiores de dezesseis anos, em quantidade proporcional às populações de todos os Estados da Federação. Confira-se quadro que compara a confiança da população em várias instituições, entre elas o Governo Federal, órgão provedor da seguridade social no Brasil:

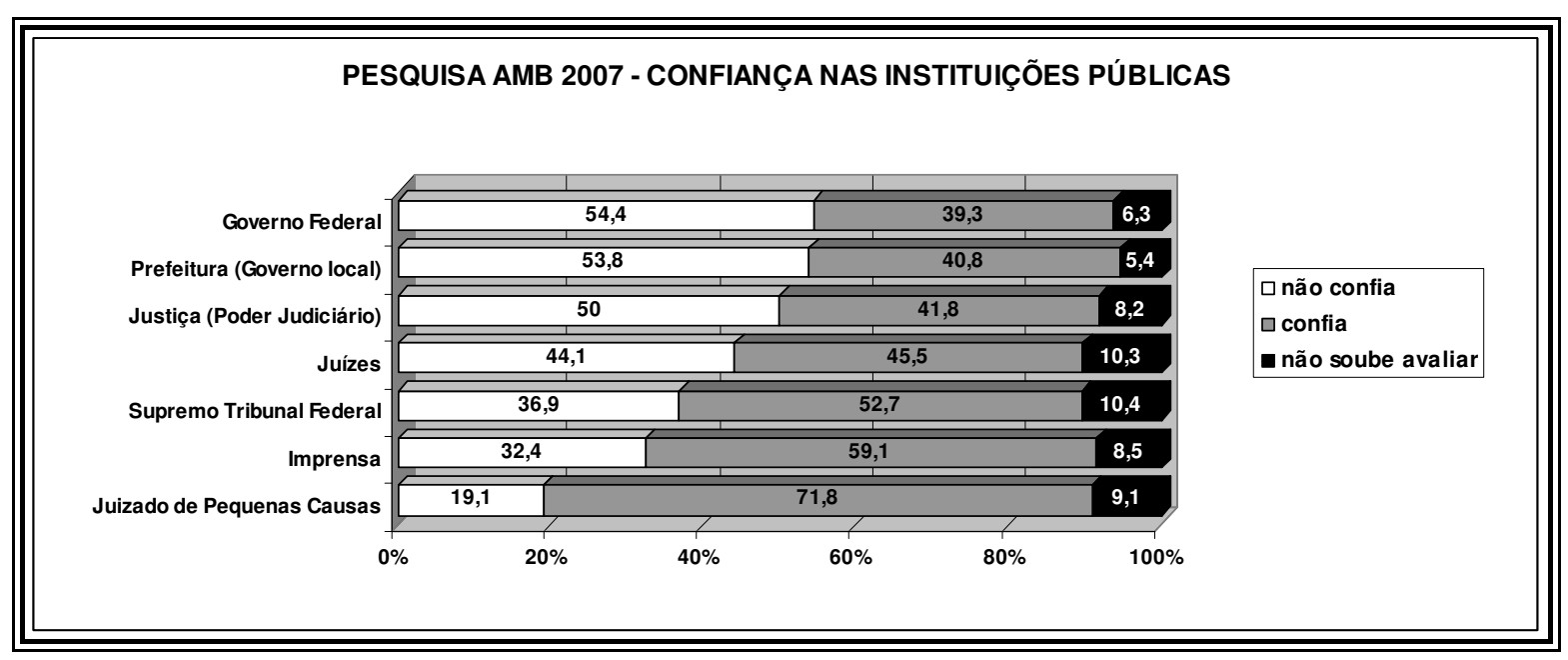

Nota-se que, das instituições pesquisadas, o Governo Federal obteve a menor taxa de confiança da população, apenas 39,3\%. Conclui-se, sem maior dificuldade, que os indivíduos não se sentem protegidos e amparados pelos órgãos provedores da seguridade

subvenções às instituições privadas com fins lucrativos, bem como a participação direta ou indireta de empresas ou capitais estrangeiros na assistência à saúde no País, salvo nos casos previstos em lei.

${ }^{247}$ Acerca do sistema privado de previdência dispõe o texto constitucional: Art. 202. O regime de previdência privada, de caráter complementar e organizado de forma autônoma em relação ao regime geral de previdência social, será facultativo, baseado na constituição de reservas que garantam o benefício contratado, e regulado por lei complementar. Entretanto, repetindo regra estabelecida para as empresas privadas que exploram a assistência à saúde, é vedado o aporte de recursos a entidade de previdência privada pela União, Estados, Distrito Federal e Municípios, suas autarquias, fundações, empresas públicas, sociedades de economia mista e outras entidades públicas, salvo na qualidade de patrocinador, situação na qual, em hipótese alguma, sua contribuição normal poderá exceder a do segurado.

${ }^{248}$ Diante da propalada "falência" do sistema público, cuja amplitude talvez seja propositalmente dilatada, a opção de "saída" se revela sedutora, assim como, face à violência não controlada pelas autoridades, as famílias se defendem sob grades. Contudo, assim como os habitantes dos condomínios protegidos não podem evitar que o fornecimento de água venha das mesmas fontes que abastecem bairros pobres, que os empregados se atrasem por conta da ineficiência dos transportes, ou que parentes do zelador pertençam à quadrilha que atua em morro próximo, também os arranjos microcorporativos da seguridade nas empresas estão longe de garantir o sucesso esperado, seja em termos de proteção para o trabalhador, seja como estímulo à modernização da economia (VIANNA, Maria Lucia T. Werneck. Articulação de Interesses, Estratégias de Bem-estar e Políticas Públicas: A Americanização (perversa) da Seguridade Social no Brasil. Tese de Doutorado. Instituto Universitário de Pesquisas do Rio de Janeiro. Rio de Janeiro, 1995. p. 214).

249 Disponível em <http://www.amb.com.br/portal/docs/noticias/pesquisa_opiniao.pdf>, acesso em 10.jan.2008. 
social no Brasil e procuram, a todo sacrifício, contratar junto a empresas privadas a garantia e proteção que não são providenciadas pelo sistema oficial. Neste diapasão, diante do desmonte da previdência social, inevitável que se pondere acerca da necessidade da tutela da seguridade social pelo Direito Penal.

Tal crítica, há que se confessar, talvez reforce o argumento daqueles que pugnam pela maior ferocidade do aparelho punitivo penal, que utilizariam a seguinte e simplista lógica: a seguridade social sofre das mazelas atuais pela falta de repressão das condutas que a ofendem. Basta, contudo, que se debruce com maior racionalidade sobre a questão para que se conclua que a violência da resposta do aparelho repressivo não tem o condão de diminuir as condutas criminosas, pois se tal hipótese correspondesse à realidade seria suficiente que, por determinação legislativa, todas as reprimendas do Código Penal fossem decuplicadas, o que deveria levar, necessariamente, à extirpação do crime em nossa sociedade, fato que certamente não ocorreria.

Portanto, o completo esvaziamento e ineficiência do aparelho estatal - que não instrumentaliza adequadamente o pagamento de benefícios e aposentadorias, assim como não providencia o amparo à saúde de modo adequado, tornando inócuo o sistema de proteção - faria injustificável a criminalização das condutas que lhe ofendam.

Para reforçar tal argumentação figure-se a hipótese de empregador que desconta dos vencimentos dos empregados o percentual a ser destinado à seguridade social, mas, ao invés de recolher o montante aos cofres públicos, utiliza-se da exata quantia deduzida dos salários para custear em favor dos empregados um plano de previdência privada ou de seguro saúde. Haveria fundamentos de direito e justiça aptos a serem utilizados em desfavor do empregador e o levarem, conseqüentemente, à condenação criminal? A resposta, óbvia, é negativa.

Compare-se, na tabela infra, números que servem de dados investigativos para que se procure estabelecer o impacto da criação das novas figuras penais introduzidas pela Lei $n^{\circ}$ 9.983/00. Foram colhidos em dados oficiais os valores do Produto Interno Bruto (PIB) e valores de recolhimento das Guias de Previdência Social (GPS), instrumento utilizado pelas empresas para o pagamento de suas obrigações contributivas. Tomaram-se os dados desde 1997 até 2003, com a intenção de abranger os três anos que antecederam à edição da lei criminalizadora e os três anos que a ela se seguiram. 
A idéia é, a partir da comparação dos números, extrair dados que possibilitem concluir pela influência (ou não) da nova lei no universo dos recolhimentos, a fim de se confirmar (ou se afastar) hipótese que se funda no aumento da arrecadação causado pela ameaça da sanção penal.

Cite-se, por fim, que as condutas contra a arrecadação para a seguridade social não foram criadas pela Lei $\mathrm{n}^{\circ}$ 9.983/00, mas certamente a inclusão dos tipos no Código Penal trouxe ao mundo jurídico discussão que por muito tempo se fez presente. A criminalização das condutas pelo Código Penal, além de ter deflagrado intensa produção acadêmica, certamente contribuiu para disseminar entre a população a norma penal. Eis os dados que se oferecem à análise:

\begin{tabular}{||ccccc||}
\hline \hline ANO & PIB $^{250}$ & $\begin{array}{c}\text { RECOLHIMENTO } \\
(\text { GPS) }\end{array}$ & $\begin{array}{c}\text { PIB1 } \\
\text { RECOLHIMENTO }^{252}\end{array}$ & $\begin{array}{c}\text { EVOLUČñO } \\
\text { NO ANO }^{253}\end{array}$ \\
1997 & $1.870 .407 .027 .666,90$ & $39.391 .419 .031,00$ & $2,10 \%$ & - \\
1998 & $1.871 .068 .135 .663,19$ & $42.361 .319 .896,00$ & $2,26 \%$ & $8 \%$ \\
1999 & $1.875 .822 .113 .940,45$ & $45.989 .577 .907,41$ & $2,45 \%$ & $8 \%$ \\
2000 & $1.956 .598 .519 .234,10$ & $49.974 .909 .236,00$ & $2,55 \%$ & $4 \%$ \\
2001 & $1.982 .290 .982 .422,09$ & $56.729 .046 .029,00$ & $2,86 \%$ & $12 \%$ \\
2002 & $2.034 .982 .141 .781,48$ & $63.793 .147 .320,00$ & $3,13 \%$ & $10 \%$ \\
2003 & $2.058 .315 .650 .412,75$ & $74.467 .936 .241,00$ & $3,62 \%$ & $15 \%$ \\
\hline
\end{tabular}

Nota-se, ao analisar a série de dados do Produto Interno Bruto (PIB) que, embora tímida, em todos os anos pesquisados houve evolução dos números. Evidencia-se, portanto, crescimento econômico, o que se refletiu no aumento de arrecadação por meio das Guias de Previdência Social (GPS). A análise da segunda e terceira colunas indica que tanto Produto Interno Bruto (PIB), como arrecadação por meio de Guia de Previdência Social (GPS), obtiveram crescimento se comparado o ano anterior ao subseqüente.

Observa-se, igualmente, uma lenta evolução na quarta coluna, a indicar que ao longo dos anos a arrecadação tornou-se mais representativa, se comparada ao Produto

${ }^{250}$ Produto Interno Bruto em Reais. Disponível na página eletrônica do Banco Central do Brasil - BACEN, <www.bcb.gov.br>, acesso em 20.mai.2007.

${ }^{251}$ Recolhimento da empresas por GPS - Guia de Previdência Social em Reais. Disponível na página eletrônica do Ministério da Previdência Social, <www.mpas.gov.br>, acesso em 20.mai.2007.

${ }^{252}$ Relação PIB/RECOLHIMENTO. Em 1997 o recolhimento representou 2,10\% do PIB, e assim por diante.

${ }^{253}$ De 1997 para 1998, houve crescimento de 1,08\% na relação PIB/RECOLHIMENTO, e assim por diante. 
Interno Bruto (PIB). Tal tendência já se vinha notando nos anos que antecederam o de 2000, que trouxe a nova lei incriminadora. Portanto, além dos sucessivos crescimentos do Produto Interno Bruto (PIB) e da arrecadação por meio das Guias de Previdência Social (GPS), a cada ano, gradativamente, aumenta em números relativos a arrecadação. Se em 1997 a arrecadação pelas Guias de Previdência Social (GPS) representava 2,10\% do Produto Interno Bruto (PIB), em 2003 a arrecadação passou a montar 3,62\%. Esse crescimento já ocorria antes de 2000: de fato, desde 1997 evidencia-se elevação da arrecadação se comparada ao Produto Interno Bruto (PIB).

$\mathrm{Na}$ quinta coluna foram calculados os percentuais de crescimento da participação da arrecadação do Produto Interno Bruto (PIB), de um ano a outro. Assim, de 1997 para 1998 a taxa de aumento da arrecadação, cotejada com o Produto Interno Bruto (PIB), evoluiu cerca de 8\%. No ano subseqüente (de 1998 para 1999) a taxa de crescimento manteve-se estável, nos mesmos 8\%. No ano seguinte - 1999 para 2000 embora ainda se constate crescimento, fica patente ter havido desaceleração, já que os dados atingiram apenas $4 \%$.

Nota-se, a partir daí (2000), razoável aceleração na taxa de crescimento da arrecadação via Guia de Previdência Social (GPS) relativamente ao Produto Interno Bruto (PIB). Nota-se, também, que tal aumento coincidiu com a edição da nova lei criminalizadora, o que poderia indicar que o texto proibitivo atingira de fato seu objetivo, qual seja, evitar condutas contrárias à arrecadação. De 2000 para 2001 o crescimento foi de $12 \%$, com nova desaceleração no período 2001-2002, que registrou crescimento de apenas $10 \%$. No ano seguinte, período 2002-2003, a aceleração é retomada, e atinge o maior crescimento no período pesquisado: $15 \%$.

É certo que não se pode atribuir à nova lei incriminadora a aceleração do crescimento. Isso porque, na transição de 2001 para 2002, período posterior à edição da Lei $\mathrm{n}^{\circ}$ 9.983/00, houve desaceleração dos índices de crescimento.

A análise de outro aspecto também não permite concluir pela força intimidadora da norma penal: a evolução tecnológica dos métodos de controle. Sem dúvida a onda de informática que varreu todos os setores da vida social, inclusive os órgãos de arrecadação, contribuiu, significativamente, para o incremento dos montantes arrecadados. 
Pode-se concluir, portanto, não ter a norma incriminadora o condão de incentivar os recolhimentos à seguridade social.

\subsection{A terceira via proposta por Miguel Reale Júnior}

É de grande valia a abordagem que Miguel Reale Júnior faz da possibilidade de adoção, com relação ao fenômeno dos crimes econômicos, do exercício do controle social por um caminho intermediário, localizado entre o sistema penal clássico, sancionador, que continuaria a punir com penas privativas de liberdade e o sistema administrativo puro, das multas. Tal opção intermediária é por ele denominada de terceira via ${ }^{254}$.

As condutas humanas podem ser classificadas em três grandes grupos: as que são nocivas ao convívio social, as que a ele são benéficas e as que não trazem consigo qualquer tom de significado.

Matar e ofender a integridade física, como regra, são condutas consideradas contrárias ao bom andamento da vida social, embora os ordenamentos jurídicos, em casos excepcionais, autorizem essas ações quando, por exemplo, estão amparadas por causas excludentes de ilicitude. São condutas que trazem consigo uma carga de significado negativo, encerram um desvalor. São condutas socialmente indesejadas e, por isso, acabam alvos de repreensão social.

Dar conforto a quem tenha perdido ente querido e auxiliar o próximo materialmente são ações humanas carregadas de significados positivos. São ações agregadoras, virtuosas, agradáveis ao convívio social. As condutas dessa natureza devem ser estimuladas.

Por fim, podem ser apontadas condutas neutras, que não carregam consigo qualquer significado valorativo como, por exemplo, alimentar-se ou caminhar. São ações desprovidas de sentido ético ou moral, em relação às quais não se exprimem juízos de valor, por não deporem contra a organização social nem agregarem a ela qualquer valor.

\footnotetext{
${ }^{254}$ REALE JÚNIOR. Miguel. Despenalização no direito penal econômico: uma terceira via entre o crime e a infração administrativa? Revista Brasileira de Ciências Criminais, São Paulo, v. 7, n. 28, p. 116-129, out./dez. 1999.
} 
Trazendo a discussão ao mundo jurídico, as condutas do segundo grupo (de significado positivo) e as do terceiro grupo (neutras) são denominadas lícitas, pois reproduzem práticas que não ofendem o convívio social, não afetando os relacionamentos humanos de modo deletério. A reiterada prática dessas condutas não atrapalha o convívio social, sendo que as do segundo grupo até são muito recomendáveis e desejadas, devendo sua prática ser incentivada. São condutas que se amoldam às expectativas sociais.

As ações do primeiro grupo encerram significado negativo, frustram as expectativas sociais, degradam o convívio humano e, por isso, pretende-se sejam evitadas. São acoimadas de ilícitas e encerram em si, a depender da intensidade de seu caráter desagregador, mais ou menos desvalor.

Sendo assim, já num segundo momento, após serem os três tipos básicos de condutas submetidos à esfera jurídica, podemos identificar dois grandes grupos de ações humanas, as lícitas (que congregam as condutas virtuosas e as neutras) e as ilícitas. Estas últimas é que receberão especial atenção do Direito, pois como sistema de controle social $^{255}$, ao Direito cabe identificar e repreender ações que se desgarram das expectativas sociais, frustrando-as.

No que se pode chamar de terceiro momento, cabe imputar a cada uma das condutas ilícitas a sanção que mais se lhe adequa. A fim de que essa imputação seja bem sucedida, faz-se imprescindível a acurada análise do bem jurídico em questão, pois ele exerce, na esfera da Política Legislativa, importante função ao orientar o legislador na decisão de qual conduta deva ser reprimida por meio da ameaça penal ou de sanção administrativa ${ }^{256}$.

A questão cinge-se, nessa ordem de idéias, a analisar qual sanção, entre as inúmeras possíveis, tem capacidade de cumprir, com mais efetividade, a missão de tutelar o bem jurídico protegido que, conclui-se pela análise já realizada ${ }^{257}$, é a arrecadação para a seguridade social. Antes de atribuir sanção à conduta há que se perquirir se o bem jurídico em questão tem possibilidade de ser tutelado pelo Direito Penal, pois este deve ser

\footnotetext{
${ }^{255}$ Conforme capítulo 6.1 .

${ }^{256}$ REALE JÚNIOR. Miguel. Despenalização no direito penal econômico: uma terceira via entre o crime e a infração administrativa? Revista Brasileira de Ciências Criminais, São Paulo, v. 7, n. 28, p. 116-129, out./dez. 1999.

${ }^{257}$ Conferir capítulo 3.1.2.5.
} 
reservado apenas às condutas que ofendam bens portadores de dignidade especial, bens que possuam estatura relevante dentro da organização social. Confirmando tal raciocínio $^{258}$,

a norma penal não surge da crença singela de que determinada conduta deve ser punida, porém da real necessidade de se tutelar o bem pretendido de uma forma socialmente mais severa, mais rígida, mais incisiva e também mais enérgica e violenta, posto que a pena atinge o valioso direito de liberdade.

Essa premissa já foi estabelecida no capítulo 3.1.2, no qual se concluiu pela possibilidade de a arrecadação para a seguridade social ser penalmente tutelada. Confirmada a possibilidade da tutela do bem jurídico pela norma penal, a questão está apta a ser enfrentada: qual ramo do Direito oferece melhor tutela, no caso da arrecadação para a seguridade social, o Penal ou o Administrativo?

Haveria diferença de sentido entre a sanção penal e a administrativa? Ou, no mesmo rol de indagações, o fato de um bem jurídico ser tutelado pelo Direito Penal o torna mais valioso e relevante se comparado àquele que é tutelado pelo Direito Administrativo? A resposta é negativa. Para Miguel Reale Júnior ${ }^{259}$, se há defesa de bem jurídico fundamental pouco importa que a via seja administrativa ou penal, posto que sempre, diante da importância do bem jurídico, estar-se-á protegendo a sociedade, isto é a "existência social”. O autor concluiu que é a eficácia social a balizadora da escolha pela via penal ou administrativa de tutela.

Na mesma linha Helena Regina Lobo da Costa, ao afirmar que não há matérias em que obrigatoriamente deve haver criminalização, independentemente de quão importante seja o bem jurídico ${ }^{260}$.

Chega-se à conclusão de que, por não haver diferença de essência entre o ilícito administrativo e penal, resta ao legislador optar, como já dito, pela via que apresente maior efetividade social.

${ }^{258}$ IBAIXE JUNIOR, João. Crimes Previdenciários: garantismo penal e responsabilidade da pessoa jurídica. Revista de Previdência Social. São Paulo, v. 27, n. 272, p. 549-51, jul. 2003.

${ }^{259}$ REALE JÚNIOR. Miguel. Despenalização no direito penal econômico: uma terceira via entre o crime e a infração administrativa? Revista Brasileira de Ciências Criminais, São Paulo, v. 7, n. 28, p. 116-129, out./dez. 1999.

${ }^{260}$ COSTA, Helena Regina Lobo da. Proteção ambiental, direito penal e direito administrativo. Tese de Doutorado. Faculdade de Direito da Universidade de São Paulo, São Paulo, 2007. p. 214. 
6.3 O delito previdenciário e o Direito Penal Econômico

Conforme explicitado, Miguel Reale Júnior defende a adoção do Direito Administrativo Penal para os nomeados delitos econômicos, especialmente aqueles da Lei $\mathrm{n}^{\mathrm{o}}$ 8.137/90. Estariam os delitos previdenciários incluídos entre o objeto de estudo do Direito Penal Econômico?

Necessário se faz, a fim de construir o conceito de Direito Penal Econômico, abordar alguns aspectos da definição de Direito Penal.

O conceito de Direito Penal admite várias acepções. Basileu Garcia ${ }^{261}$ adverte que há de se considerar a distinção comum aos demais ramos da ciência jurídica, que separa o direito subjetivo do direito objetivo:

Direito Penal subjetivo é o jus puniendi do Estado, o direito de punir. Só o
Estado pode exercếlo. Não se concebe Direito Penal, senão pôsto em prática
pela autoridade pública. Estamos distanciados, de muitos séculos, da época da
vingança privada, primeira manifestação da justiça punitiva. No seu aspecto
objetivo, o Direito Penal é o conjunto de normas jurídicas que o Estado
estabelece para combater as infrações penais, consistentes em crimes ou delitos e
contravençães, disciplinando a aplicação assim das penas como das medidas de
segurança.

Em continuação, e em referência ao aspecto objetivo, aduz o ilustre professor que o Direito Penal ainda comporta uma subdivisão, entre Direito Penal substantivo e o Direito Penal adjetivo. Aquele é representado pela lei penal e tem por função determinar os delitos e as sanções, aí incluídas as penas e as medidas de segurança. Por sua vez, o Direito Penal adjetivo, também denominado de Direito Processual Penal ou Judiciário Penal, com aquele se entrelaça, já que se vai constituindo como suporte à aplicação do Direito Penal objetivo.

Zaffaroni e Pierangeli ${ }^{262}$ também optam por cindir o conceito de Direito Penal. Sob o gênero conceito geral de direito penal, os autores distinguem duas entidades, a saber: o conjunto de leis penais, isto é, a legislação penal; e o sistema de interpretação desta legislação, ou seja, o saber do direito penal. Portanto, para os autores, sob o primeiro ponto de vista o Direito Penal

${ }^{261}$ GARCIA, Basileu. Instituições de Direito Penal. v. 1. t. 1. São Paulo: Max Limonad, 1973. p. 8.

${ }^{262}$ ZAFFARONI, Eugenio Raúl; PIERANGELI, José Henrique. Manual de Direito Penal Brasileiro: parte geral. 5. ed. São Paulo: Revista dos Tribunais, 2004. p. 85. 
é o conjunto de leis que traduzem normas que pretendem tutelar bens jurídicos, e que determinam o alcance de sua tutela, cuja violação se chama "delito", e aspira a que tenha como conseqüência uma coerção jurídica particularmente grave, que procura evitar o cometimento de novos delitos por parte do autor.

Na segunda acepção, o Direito Penal é o sistema de compreensão (ou de interpretação) da legislação penal.

Luis Jiménez de Asúa ${ }^{263}$, após advertir sobre a pouca utilidade de um conceito apriorístico, formula a seguinte definição de Direito Penal:

conjunto de normas y disposiciones jurídicas que regulan el ejercicio del poder sancionador y preventivo del Estado, estableciendo el concepto de delito como pressuposto de la acción estatal, así como la responsabilidad del sujeto activo, y asociando a la infraccion de la norma uma pena finalista o una medida aseguradora.

Entre nós, Heleno Cláudio Fragoso ${ }^{264}$, com o poder de síntese que lhe é peculiar, assim define o Direito Penal: conjunto de normas jurídicas mediante as quais o Estado proíbe determinadas ações ou omissões, sob a ameaça de característica sanção penal. Para José Frederico Marques ${ }^{265}$, o Direito Penal compreende

o conjunto de normas que ligam ao crime, como fato, a pena como conseqüência, e disciplinam também as relações jurídicas daí derivadas, para estabelecer a aplicabilidade de medidas de segurança e a tutela do direito de liberdade em face do poder de punir do Estado.

Pois bem. Expostos os diversos pensamentos que procuram explicar e delimitar o Direito Penal, imperioso avançar rumo à construção do conceito de Direito Penal Econômico.

Segundo Mauricio Antonio Ribeiro Lopes ${ }^{266}$, uma primeira característica do Direito Penal Econômico é a sua equivocidade conceitual ou ao menos indeterminação delimitativa do objeto de estudo. E acrescenta:

essa equivocidade é determinada em virtude de uma maior fragmentariedade dos elementos centrais da identificação do bem jurídico penal econômico relevante e

\footnotetext{
${ }^{263}$ ASÚA, Luis Jiménez de. Tratado de Derecho Penal. t. 1. 2. ed. Buenos Aires: Losada, 1956. p. 31.

${ }^{264}$ FRAGOSO, Heleno Cláudio. Lições de Direito Penal. A nova Parte Geral. Rio de Janeiro: Forense, 1986. p. 1.

${ }^{265}$ MARQUES, José Frederico. Curso de Direito Penal. v. 1. São Paulo: Saraiva, 1954. p. 11.

${ }^{266}$ LOPES, Mauricio Antonio Ribeiro. O princípio da proporcionalidade no direito penal econômico. Temas de Direito Penal Econômico. org. Roberto Podval. São Paulo: Revista dos Tribunais, 2000.
} 
das complicadas técnicas de política legislativa na construção de superestruturas punitivas.

Nessa seara, assinalam os professores Jorge de Figueiredo Dias e Manuel da Costa Andrade ${ }^{267}$ :

o Direito Penal Económico começa a aparecer ao estudioso como um conjunto heterogéneo de normas que reivindicam a pertinência a esta zona do jurídico. Impõe-se por isso a adopção dum critério viável que nos oriente na determinação do conteúdo e limites do Direito Penal Económico.

No mesmo sentido, Eduardo Reale Ferrari adverte: um dos tópicos mais difíceis a serem enunciados, consiste em tentar conceituar Direito Econômico, tornando-se ainda mais complexo definir a expressão Direito Penal Econômico. Prossegue em sua análise o citado autor: a dificuldade em estabelecer um conceito de Direito Econômico, torna ainda mais instigante buscar um critério reitor que possibilite compreender a amplitude ou restrição de tal temática $(. . .)^{268}$.

Fabio Konder Comparato, referenciado por Manoel Pedro Pimentel assim se expressa: o novo Direito econômico surge como o conjunto das técnicas jurídicas de que lança mão o Estado contemporâneo na realização de sua política econômica. Ele constitui assim a disciplina normativa da ação estatal sobre as estruturas do sistema econômico (...).

Leciona Manoel Pedro Pimentel que as regras da ciência econômica não se confundem com as normas de Direito econômico, já que estas se prestam a ordenar $o$ relacionamento das operações de natureza econômica e aquelas a dispor a respeito da fiscalização das questões relacionadas ao interesse comum. Por fim, o conceituado jurista, não sem antes alertar para a falta de uniformidade de pensamento dos diversos autores, arrisca um conceito de Direito Penal Econômico: conjunto de normas que têm por objetivo sancionar, com as penas que lhe são próprias, as condutas que, no âmbito das relações econômicas, ofendam ou ponham em perigo bens ou interesses juridicamente relevantes.

\footnotetext{
${ }^{267}$ DIAS, Jorge de Figueiredo; ANDRADE, Manuel da Costa. Problemática Geral das Infracções contra a Economia Nacional. Temas de Direito Penal Econômico. org. Roberto Podval. São Paulo: Revista dos Tribunais, 2000.

268 FERRARI, Eduardo Reale. Legislação Penal Antitruste: Direito Penal Econômico e sua Acepção Constitucional. Experiências do Direito. Campinas: Millenium, 2004.
} 
Após transcrever vários outros $\operatorname{conceitos}^{269}$, o professor Manoel Pedro Pimentel busca traçar uma linha mestra, que os unifique, e acaba por concluir: nessa variedade de opiniões percebe-se um traço comum e saliente, que coloca em relevo a finalidade de proteger os bens e os interesses humanos relacionados com a economia. Vale-se o citado autor das lições de Maggiore e Santiago Sabas Ariba para demonstrar que desde há muito o Direito se ocupou dos comportamentos lesivos à economia. Nesse diapasão, o Direito romano considerava crime as infrações relativas aos preços de víveres (crimina annonae), bem como o dardanariado, o monopólio, a usura e a falsificação de pesos e medidas $(\ldots)^{270}$.

Klaus Tiedemann, citado por Eduardo Reale Ferrari, demonstra que em muitos países o Direito Econômico constitui uma área sui generis, já que não se limitaria ao Direito Administrativo, mas abarcaria, também, aspectos que formam o Direito Civil. Confira-se:

\begin{abstract}
en este sentido, el Derecho Penal Econômico se concibe ahora en Alemania de manera tan amplia, que comprende muchas matérias del derecho Comercial, de la competência de las Câmaras de Derecho Penal Econômico de los Tribunales Regionales (landgerithte) y de las fiscalias especializadas en la persecución de los delitos econômicos. Igualmente en el Derecho francês, se bien se distingue teoricamente entre "Droit dês Affaires" y "Droit Penal dês Affaires", por una parte y Derecho Econômico Adminitrativo, por la outra, las fiscalias especializadas em la persecución de los delitos econômicos, que siguen el modelo alemán y las Salas de lo Penal Econômico tienem também competência em ambas matérias. Em consequiência, por lo menos en la pratica, se percibe um cresciente acercamiento entre las matérias teoricamente separables del Derecho Comercial (Mercantil) y Derecho Econômico.
\end{abstract}

Ainda, com base em Manuel da Costa Andrade, Eduardo Reale Ferrari afirma que o Direito Penal Econômico deve restringir suas atenções às ações que tenham capacidade de turbar ou pôr em perigo a vida econômica e a ordem que a ela corresponde. Assim, a tutela do Direito Penal Econômico deve se voltar, exclusivamente, a situações de afronta a bens de desenvolvimento, serviços e produção de riquezas, desde que essenciais à sociedade. Ou seja, o objeto de tutela não pode prescindir da Dignidade Penal, conceituada como o juízo qualificado de intolerância social, demonstrando uma gravosa

\footnotetext{
${ }^{269}$ Santiago Sabas Arias, Miranda Gallino, Fontán Balestra.

${ }^{270}$ PIMENTEL, Manoel Pedro. Direito Penal Econômico. São Paulo: Revista dos Tribunais, 1973. p. 8.
} 
danosidade social, eliminando, a priori, circunstâncias meramente éticas ou imorais, como jogos de azar, bingo, loteria, usura, (... $)^{271}$.

Jorge de Figueiredo Dias e Manuel da Costa Andrade, afiançam ser impossível um conceito de Direito Penal Econômico que não homenageie a criminologia, a criminalística e a ciência jurídica. Os conceitos de caráter criminológico, segundo os destacados autores, têm origem na definição de white-collar crime de E. Sutherland.

Há também quem defenda a diferenciação sob o aspecto criminalístico, pois a complexidade das infrações à ordem econômica exigiria das autoridades públicas redobrados cuidados de investigação. Como ressaltado pelos autores, sob este aspecto (criminalístico), o Direito Penal Econômico não passaria de um Direito patrimonial especializado, cujo caráter distintivo assentar-se-ia, tão-somente, na complexidade do modus operandi.

Destaque-se, ademais, a opinião dos que remetem o Direito Penal Econômico a mero sancionador de ilícitos produzidos em outras esferas do ordenamento jurídico. Nesta ordem de idéias, o Direito Penal Econômico estaria a serviço do Direito Econômico, como reforçador das condutas que este ramo do Direito qualifica com a ilicitude. Nota-se, aqui, acentuado caráter secundário do Direito Penal, que se prestaria apenas a chancelar a desconformidade das condutas desvalorizadas pelos demais ramos do ordenamento. Outra questão que parece ser insuperável é a falta de univocidade do conceito de Direito Econômico $^{272}$.

Por fim, e como último recurso utilizado para a delimitação do conceito de Direito Penal Econômico, imprescindível transcrever a lição de Manoel Pedro Pimentel ${ }^{273}$ :

o Direito Penal econômico não se confunde com o Direito penal financeiro e
com o Direito penal tributário. É o que pensamos. São ramos distintos e, segundo
entendemos, não estão necessariamente ligados ao Direito penal administrativo.
A delimitação entre eles se faz exatamente com a delimitação dos respectivos
objetos jurídicos. O Direito penal administrativo é "el conjunto de disposiciones
que asocian al incumplimiento de um concreto deber de los particulares com la
Administración, una pena determinada (L. Jiménez de Asúa)".

${ }^{271}$ FERRARI, Eduardo Reale. Legislação Penal Antitruste: Direito Penal Econômico e sua Acepção Constitucional. Experiências do Direito. Campinas: Millenium, 2004.

${ }^{272}$ DIAS, Jorge de Figueiredo; ANDRADE, Manuel da Costa. Problemática Geral das Infracções contra a Economia Nacional. Temas de Direito Penal Econômico. org. Roberto Podval. São Paulo: Revista dos Tribunais, 2000.

${ }^{273}$ PIMENTEL, Manoel Pedro. Direito Penal Econômico. São Paulo: Revista dos Tribunais, 1973. 
Embora árdua a questão, há que se concluir estarem excluídos do conceito de Direito Penal Econômico os delitos previdenciários. O Direito Penal Econômico lida com o mercado, a relação entre os atores produtivos e os fatores utilizados para a geração de riqueza; os delitos previdenciários, por seu turno, regulam relações sociais. Cite-se percuciente comparação que aparta a ordem econômica da social, levada a efeito por Gilciane Allen Baretta ${ }^{274}$ :

\begin{abstract}
a finalidade da ordem jurídico-econômica é estabelecer os princípios e regras informadores de normas que regerão as relações econômicas, o que se dá sob dois prismas: a ordem jurídica econômica aceita e acolhe o regime econômico existente, adotando-o como base de toda a organização que a norma implanta e, por outro lado, procura criar um regime econômico (...) De outro turno, a ordem social tem como objetivo assegurar o desfrute de uma vida plena por intermédio do acesso ao trabalho.
\end{abstract}

Por certo, em determinados momentos da dinâmica social, os delitos previdenciários assumem características que indicam grande proximidade com o Direito Penal Econômico, por exemplo, quando o sujeito ativo do crime o perpetra em benefício de empresa de grande porte, ou quando as quantias apropriadas ou sonegadas se mostram de graúdo vulto. Em verdade, a apropriação indébita previdenciária e a sonegação de contribuição previdenciária, ainda que praticadas nos moldes que se acaba de citar - em grandes valores absolutos - não têm o condão de afetar a economia ou colocar em xeque a sua higidez.

Os delitos econômicos, que vão acionar o aparelho repressivo do Direito Penal Econômico, pressupõem afetação de toda a estrutura produtiva, impactando de modo deletério este ou aquele mercado e, potencialmente, lançando seus malefícios por toda a economia. Inúmeras relações jurídicas são afetadas. Imagine-se o concerto de preços de compra de matérias primas efetivado, por exemplo, pelas indústrias de confecção de tecido. As principais indústrias de tecido de determinado mercado relevante resolvem estabelecer, verbi gratia, preço máximo para a compra do algodão, forçando os produtores desse insumo a diminuírem consideravelmente suas margens de lucro. Fica rompido o natural equilíbrio do mercado, o que leva ao estabelecimento de uma relação desigual, que vai se refletir, no primeiro momento, no mercado de venda de algodão, com o arrocho dos produtores de matéria prima. Estes, por sua vez, no momento seguinte, poderão suprimir direitos trabalhistas de seus empregados, a fim de tentarem equacionar seu fluxo de caixa,

274 BARETTA, Gilciane Allen. Os crimes fiscais e previdenciários. A extinção da punibilidade. Belo Horizonte: Mandamentos, 2004. p. 21. 
o que tira poder econômico do mercado consumidor, desacelerando a economia como um todo, ocasionando verdadeiro efeito em cascata. Pelo exemplo citado se notam as infindáveis relações jurídicas perversamente atingidas pela conduta do concerto de preços exemplo clássico dos delitos econômicos.

Embora possam atingir somas consideráveis, os delitos previdenciários dizem respeito a uma relação jurídica única, entre o sujeito passivo da obrigação previdenciária (empregador) e o seu sujeito ativo (cofre público arrecadador). Não há qualquer outra afetação.

É fácil perceber, também, que os delitos econômicos, na grande parte dos casos, são perpetrados à sorrelfa, o que dificulta em muito sua investigação. Aliás, os órgãos repressores de tal prática somente percebem os efeitos das ações delituosas muito tempo depois de concretizada a prática criminosa, o que também serve para explicar a grande magnitude das lesões causadas pelos delitos econômicos. Com relação aos delitos previdenciários, a detecção da materialidade do fato criminoso é menos complexa, e pode ser realizada preventivamente, mês a mês, pelo órgão arrecadador, que tem a faculdade de lançar mão de instrumentos mais simples para controlar o cumprimento das obrigações previdenciárias. Para tanto, é necessário que se verifique, por exemplo, a folha de pagamento das empresas, e que se coteje os valores descontados com aqueles recolhidos aos cofres previdenciários em guia própria, o que há de ser feito por auditor fiscal do trabalho. Os próprios trabalhadores e sindicatos também podem realizar essa fiscalização, solicitando, mês a mês, a apresentação dos documentos que comprovam o recolhimento dos valores.

Esses os motivos que fazem concluir pela inviabilidade de classificação dos delitos previdenciários entre os chamados delitos econômicos, ficando esses afastados, por conseguinte, do Direito Penal Econômico.

\subsection{Sugestão de lege ferenda}

Mesmo não constituindo os delitos contra a arrecadação da seguridade social parte do chamado Direito Penal Econômico, como anteriormente se quis demonstrar ${ }^{275}$, as

\footnotetext{
${ }^{275}$ Confira-se capítulo 6.3.
} 
lições de Miguel Reale Júnior acerca de descriminalização, descritas no capítulo 6.2, supra, as sugestões da doutrina administrativista, bem como as experiências legislativas de outros países permitem propor um novo modelo de tutela para as condutas contrárias à arrecadação para o custeio da seguridade social.

Para elaborar a proposta que seguirá, leva-se em consideração, também, relativa falta de concretude das sanções penais na sociedade contemporânea. Explica-se.

Aquele que realiza condutas desviadas dificilmente agiria se tivesse a plena convicção de que seria apanhado em seu ato delituoso. Argumente-se com o exemplo das multas administrativas de trânsito: se o motorista sabe que em determinado trecho de uma rodovia existe controle eletrônico de velocidade, dificilmente naquele trecho ultrapassará, voluntariamente, a marca permitida. No entanto, basta a distância de alguns metros para que o motorista retome a velocidade proibida, em clara transgressão às normas de circulação de veículos automotores. Não se está querendo defender que se haveria de aplicar penas mais severas ou tipificar criminalmente um número maior de condutas. A efetiva concretude das sanções não se resolve com o endurecimento do Direito Penal, ou com idéias de tolerância zero.

Argumentar que a falta de concretude das sanções é fator que fomenta comportamentos contrários ao correto desenvolvimento da vida social significa defender que, sem qualquer dúvida, muitas pessoas escolhem comportamentos que sabem ser danosos porque têm a plena certeza de que não serão alcançadas por qualquer espécie de sanção. Não se defende a mitigação de instrumentos de garantias individuais dos acusados ou qualquer outra forma de atalho mais rápido à aplicação da resposta estatal. No entanto, as escolhas comportamentais seriam outras se, por exemplo, os executivos de grandes empresas soubessem que a apropriação indébita previdenciária ou a sonegação de contribuição previdenciária seriam descobertas e investigadas pelas autoridades competentes. Porque, segundo Jefferson Aparecido Dias, hoje ${ }^{276}$,

se fiscalizada e apurada eventual irregularidade, a empresa poderá discutir
administrativa e judicialmente se aqueles valores são devidos e, se ao final, se
concluir que eles são efetivamente devidos, poderá parcelar o débito ou mesmo
pagá-lo, total ou parcialmente, e usufruir as inúmeras benesses previstas na
legislação para o criminoso previdenciário (...)

${ }^{276}$ DIAS, Jefferson Aparecido. Crime de Apropriação Indébita Previdenciária. CP, art. 168-A, § 1 $1^{\circ}$ inc. I. 2. ed. Curitiba: Juruá, 2007. p. 31. 
Perfilhando entendimento bastante assemelhado, no que tange aos crimes ambientais, Helena Regina Lobo da $\operatorname{Costa}^{277}$, para quem a imputação de condutas verificadas em contextos empresariais também oferece dificuldades em muitos casos intransponíveis ao direito penal. Aduz, ainda, que a estrutura empresarial acarreta divisão e dispersão de tarefas, de responsabilidades, de fluxo de informações e da comunicação. Conclui, referida autora, que diante desse cenário, a responsabilização individual se torna bastante difícil.

Portanto, a sugestão de alteração legislativa deve apostar na possibilidade de modificação do sentimento de impunidade que grassa entre os adeptos de práticas sociais pouco recomendáveis, talvez - e paradoxalmente, a princípio, - descriminalizando as condutas lesivas à seguridade social. A idéia que se advoga é simples: a sanção penal - e por consequiência a pena privativa de liberdade - seria definitivamente afastada. As condutas menos lesivas, que não afetem substancialmente a arrecadação do órgão previdenciário, não seriam perseguidas, ficando reservadas as lesões mais significativas à tutela do Direito Administrativo Penal.

As lesões menos expressivas não seriam perseguidas, nem penal nem administrativamente. É que a União já conta com mecanismo de recuperação dessas quantias, a execução fiscal, que devolverá aos cofres públicos os valores não recolhidos com todos os acréscimos legais de multa, juros e correção monetária. Contra as pessoas jurídicas existe também outro mecanismo de pressão para a arrecadação, que é constitucionalmente previsto no artigo $195 \S 3^{\circ}$ da Carta de 1988. Apenas as ofensas mais expressivas, sejam praticadas por pessoas físicas ${ }^{278}$, sejam praticadas por pessoas jurídicas, seriam perseguidas por um Direito Administrativo Penal.

Conforme demonstrado no capítulo 4.1, supra, em Portugal são consideradas criminosas, apenas, as sonegações de contribuição que somem $€$ 7.500. Na Itália, as que alcancem, ao menos, cinco milhões de liras. A lei espanhola fixa o piso mínimo de $€$ 120.000. Parece ser adequado estabelecer um patamar de corte razoável, a fim de poder

${ }^{277}$ COSTA, Helena Regina Lobo da. Proteção ambiental, direito penal e direito administrativo. Tese de Doutorado. Faculdade de Direito da Universidade de São Paulo, São Paulo, 2007. p. 220.

${ }^{278}$ A sugestão que se fará a seguir é de delimitação de um piso mínimo, acima do qual seria chamado à ação o Direito Administrativo Penal. O estabelecimento desse piso, por certo, colocaria fora do alcance do Direito Administrativo Penal grande parte das pessoas físicas, mas é necessário que se mantenha a possibilidade de persecução contra as pessoas físicas pois o que dá a linha divisória é a magnitude da lesão, e não a natureza do agente. 
dispensar tratamentos distintos a lesões que, sem qualquer dúvida, são distintas, e resultam de atos que têm distintos desvalores e resultados. A existência de patamar mínimo para que, a partir dele se inicie a perseguição do autor dos fatos é defendida por Heloisa Estellita Salomão ${ }^{279}$, que sugere sejam excluídas do campo da ilicitude quantias irrisórias. Funda sua sugestão na opinião de Maurício Antonio Ribeiro Lopes:

para dar validade sistemática à irrefutável conclusão político-criminal de que o
Direito Penal só deve ir até onde seja necessário para a proteção do bem jurídico,
não se ocupando de bagatelas, é preciso considerar materialmente atípicas as
condutas lesivas de inequívoca insignificância para a vida em sociedade.

A proposta que se faz é estabelecer um valor variável, passível de correção anual. Atrelado inicialmente ao salário mínimo e, anualmente, corrigido por ato do Tribunal Administrativo Penal. Por exemplo, cem salários mínimos vigentes à época do fato. Assim, as lesões inferiores a cem salários mínimos não seriam tuteladas por processo próprio, bastando a execução civil dos valores não recolhidos. O pagamento da contribuição, após descoberto seu não recolhimento, ensejaria - como de fato já enseja uma significativa redução na multa estipulada. Por outro lado, as lesões superiores passariam à tutela do Direito Administrativo Penal, sistema defendido por Miguel Reale Júnior para os delitos econômicos, e que se sugere seja estendido aos delitos previdenciários.

Uma das mazelas do atual sistema de Direito Penal é a extinção da punibilidade pelo pagamento do valor devido. O pagamento das contribuições não recolhidas não pode levar à extinção da persecução, como hoje ocorre. A sanha arrecadatória hodierna desprestigia todo o sistema de Direito Penal. Anote-se, em primeiro lugar, que a extinção da punibilidade pelo pagamento faz os indivíduos deixarem de acreditar nos órgão de distribuição da justiça, e reduz a questão criminal a uma mera questão financeira: o acusado que possui recursos quita seus débitos e, de um momento para o outro, põe fim ao processo. Aos que não conseguem liquidar com a dívida resta a persecução penal, com a ameaça de pena de prisão.

A extinção da punibilidade pelo pagamento, se examinada de forma coerente e sem paixões, reforça a idéia de prisão por dívida, expediente repudiado há tempos e vedado pelo artigo $5^{\circ}$, inciso LXVII da Constituição da República. Hugo de Brito Machado,

${ }^{279}$ SALOMÃO, Heloisa Estellita. Novos Crimes Previdenciários - Lei no 9.983/00, de 14 de julho de 2000 : Primeiras Impressões. Revista Dialética do Direito Tributário. São Paulo, n. 64, p. 70-90, jan. 2001. 
escorando-se na lição de Celso Ribeiro Bastos, assevera que nos tempos modernos já não se aceita mais prisão do devedor inadimplente, sendo cabível, em seu lugar, a execução do patrimônio responsável por dívida. Preleciona, ainda, referido autor: a norma que proíbe a prisão por dívida alberga direito à liberdade, colocando-o em um patamar superior ao direito de receber um crédito ${ }^{280}$.

Poder-se-ia, pelo raciocínio que a seguir se expõe, serem os tipos penais dos artigos 168-A e 337-A do Código Penal considerados inconstitucionais por ofensa ao artigo $5^{\circ}$, LXVII da Constituição da República ${ }^{281}$. Sabe-se que o ilícito penal nos crimes em questão demanda, além da dívida, uma fraude ${ }^{282}$. É certo, igualmente, que não se admite prisão por dívida além dos casos em que existe expressa autorização constitucional, mas a fraude, esta sim, poderia, em tese, ser sancionada pelo Direito Penal. Fica evidente que os crimes em questão são de natureza complexa, pois para serem caracterizados há necessidade da dívida e da fraude. O que traz perplexidade é o fato da punibilidade ser extinta pelo pagamento da dívida, o que também, como num abracadabra, extingue a fraude e todo o desvalor que a conduta encerra. É permitido deduzir, portanto, que ao se estabelecer a extinção da punibilidade pelo puro e simples pagamento da dívida, o nãopagamento da dívida impõe a punibilidade. E aí reside a crítica que se pode lançar contra o instituto da extinção da punibilidade pelo pagamento, pois sua integração com os artigos 168-A e 337-A do Código Penal leva à conclusão que a punibilidade, na verdade, tem origem na ausência de pagamento, o que contraria frontalmente o texto constitucional.

Imagine um acusado que esteja presente, por exemplo, ao ato de interrogatório em ação penal que responde por sonegação de contribuição previdenciária. O magistrado que preside o ato, por óbvio, tem o dever de informar ao acusado - o que já deve ter sido feito por seu defensor - que basta sacar dos bolsos um talão de cheques e acertar o valor devido. A conduta lhe será perdoada; esquecidos todos os falsos que eventualmente tenha praticado, e a punibilidade extinta, sem qualquer outra conseqüência. Não existe

\footnotetext{
280 MACHADO, Hugo de Brito. Apropriação indébita e dívida de tributo. IOB - Repertório de Jurisprudência civil, processual, penal e comercial. São Paulo, n. 12, p. 229-30, jun. 1994.

${ }^{281}$ Não haverá prisão por dívida salvo a do responsável pelo inadimplemento voluntário e inescusável de obrigação alimentícia e a do depositário infiel.

${ }^{282}$ Não fosse assim e se estaria, indubitavelmente, defronte a tipo penal inconstitucional ou, no mínimo, ilegal. Se bastasse à configuração do delito o não recolhimento, independentemente da anterior apropriação do valor arrecadado, estar-se-ia cominando à inadimplência uma sanção penal (SALOMÃO, Heloisa Estellita. O crime de não-recolhimento de contribuições previdenciárias. Revista Dialética de Direito Tributário. São Paulo, n. 6, p. 36-47, mar. 2006).
} 
condenação. Não existe reincidência e, por certo, não pode haver desabono de seus antecedentes.

O magistrado deixa de judicar e passa a atuar como mero coletor de valores, responsável por ajudar o Governo Federal a aumentar a arrecadação das contribuições. $\mathrm{O}$ Ministério Público, nesta linha de raciocínio, funciona quase que figurativamente, apenas chancelando o pagamento realizado. $\mathrm{O}$ ato de pagar não se reveste de qualquer sentido ético, e o acusado pode, quantas vezes entender, valer-se do mesmo expediente. Não há contra isso qualquer repreensão legal, já que se trata de gozo de direito legalmente previsto.

O juiz tem subtraído seu papel de julgar e o acusado sente-se diante de um magistrado impotente, o que retira credibilidade do poder judiciário, que é refém do texto legal e tem obrigação de admitir essa forma de resolução do conflito. Não resta ao acusado qualquer ônus; ele se sente imune aos fatos e tem reforçada a crença no dinheiro, como único método de resolução do conflito.

Outra incoerência da extinção da punibilidade pelo pagamento nos crimes em que ela é admitida reside em uma quebra de linearidade no sistema de persecução penal. Fica corrompida a idéia de retributividade inerente ao Direito, e tão cara ao Direito Penal. Outros crimes, de monta muito menor, e de insignificante repercussão social, não têm sua punibilidade extinta pela recomposição (monetária) da situação que se verificava antes dos fatos. O furtador de uma bicicleta, caso devolva o bem, e desde que tenha reconhecido em seu favor o arrependimento posterior ${ }^{283}$, poderá ser agraciado, no máximo, com uma diminuição de pena. Passa a ter seu nome no rol dos culpados e perde a primariedade, isso tudo depois de ter atravessado, na condição de acusado, o árduo processo penal.

Ficariam assim os Tribunais de Direito Administrativo Penal responsáveis pela análise e julgamento de casos que envolvam maiores lesões ao bem jurídico.

A doutrina administrativista discute a criação de órgãos públicos que, guardadas as devidas proporções, poderiam inspirar a criação dos Tribunais

${ }^{283}$ Código Penal, artigo 16. Nos crimes cometidos sem violência ou grave ameaça à pessoa, reparado o dano ou restituída a coisa, até o recebimento da denúncia ou da queixa, por ato voluntário do agente, a pena será reduzida de 1 (um) a 2/3 (dois terços). 
Administrativos Penais ${ }^{284}$. Floriano de Azevedo Marques Neto ${ }^{285}$ propõe a instituição de Agências Reguladoras Independentes (ARIs) ${ }^{286}$, para equacionar a regulação de mercados econômicos. Essas Agências seriam consideradas um tipo específico de órgãos públicos e teriam uma ampla gama de competências associada a uma alta especialização técnica (...). Tais agências deveriam atuar em mercados relevantes ou cuja essencialidade da atividade justifiquem essa intervenção.

Na concepção do autor ${ }^{287}$, esses órgãos seriam dotados de inúmeros poderes dentre os quais, interessam ao presente estudo, o poder fiscalizador, o poder sancionatório e o poder de recomendação. Os três poderes seriam exercidos pelos Tribunais Administrativos Penais.

O poder fiscalizador seria praticado por meio do acompanhamento das arrecadações mensais, por exemplo, exigindo a apresentação das folhas de pagamento e das guias de recolhimento. Poderiam ser firmados convênios com os sindicatos a fim de que estes, corretamente instruídos, pudessem acompanhar os recolhimentos das contribuições previdenciárias a cargo das pessoas jurídicas. O poder sancionatório consistiria, basicamente, na condução de procedimentos apuratórios de apropriação indébita previdenciária ou de sonegação de contribuição previdenciária, que resultariam na aplicação de advertências e multas. O poder de recomendação, finalmente, daria ao Tribunal Administrativo Penal prerrogativas de orientar ou informar o poder político

\footnotetext{
${ }^{284}$ Esses órgãos, embora denominados "Tribunais", não seriam integrantes do Poder Judiciário, tal qual acontece, por exemplo, com os Tribunais de Conta ou Tribunais de Impostos e Taxas, nem seriam compostos por magistrados.

${ }^{285}$ MARQUES NETO, Floriano Azevedo. Agências Reguladoras Independentes. Fundamentos e seu Regime Jurídico. Belo Horizonte: Fórum, 2005. p. 46.

${ }^{286} \mathrm{O}$ autor, entre as atividades que poderiam ser tuteladas pelas Agências Reguladoras Independentes (ARIs), cita as financeiras, de crédito, seguros, previdência ou que envolvam risco sistêmico (...) MARQUES NETO, Floriano Azevedo. Agências Reguladoras Independentes. Fundamentos e seu Regime Jurídico. Belo Horizonte: Fórum, 2005. p. 168. sem grifos no original.

${ }^{287}$ Frise-se, novamente, que o estudo empreendido por Floriano de Azevedo Marques Neto teve, como arcabouço, o sistema de regulação econômica, e se dedicou, com bastante ênfase, à tarefa de sugerir a criação do órgão público responsável pela gestão desse sistema de regulação. É, portanto, um contexto relativamente diferente se comparado ao universo das condutas atentatórias à arrecadação para a seguridade social. Entretanto, o estudo desenvolvido pelo autor referido se mostra bastante útil na medida em que muitas soluções e idéias sugeridas podem ser aproveitadas na construção dos Tribunais Administrativos Penais.
} 
(Legislativo e Executivo), sugerindo medidas ou decisões a serem tomadas no âmbito das políticas públicas, desenvolvendo atividade de inteligência e suporte ${ }^{288}$.

Aos Tribunais Administrativos Penais deverão ser carreados recursos públicos suficientes a seu aparelhamento, garantindo independência e uma prestação jurisdicional mais ágil aos casos concretos que, certamente, demandam resposta incisiva.

Essa terceira via contaria com a adoção de alguns institutos do Direito Penal tradicional como, por exemplo, o princípio da legalidade, os critérios de tipicidade, a irretroatividade de lei mais gravosa e a retroatividade de lei mais benigna. Por outro lado, poderia ser desnecessária a prova do dolo do agente, através de uma presunção de dolo, que seria afastada, por exemplo, se provado erro de tipo ou ocorrência de força maior ${ }^{289}$.

Na mesma linha, sugere Floriano de Azevedo Marques Neto ${ }^{290}$ : tanto na atividade de fiscalização, como na atividade sancionatória, é de suma importância o respeito aos princípios da legalidade e da proporcionalidade, como, aliás, é próprio do direito administrativo sancionador como um todo. A legalidade, seria entendida tanto no seu conceito material (previsão legal da punição da conduta que estabeleça com clareza a conduta punível, as penas e a autoridade competente para impô-las), como no seu sentido procedimental (respeito ao contraditório, à ampla defesa, etc). Em relação à proporcionalidade, indicaria respeito aos requisitos da necessidade, adequação $e$ ponderação (proporcionalidade em sentido estrito).

Os componentes dos Tribunais Administrativos Penais teriam mandato por prazo determinado e, enquanto o exercessem estariam assegurados pelas prerrogativas dos $\operatorname{magistrados}^{291}$. Não seriam juízes, mas teriam as garantias que lhes são inerentes. A

\footnotetext{
${ }^{288}$ Uma vez que os membros dos Tribunais Administrativos Penais teriam amplo conhecimento técnico acerca da matéria, poderiam aconselhar a propositura de Projetos de Lei que melhorassem o sistema de custeio e arrecadação, ou poderiam estudar eventual alteração das alíquotas de contribuição, por exemplo. O exercício do poder de recomendação estabeleceria um perene fórum de estudos dos problemas e soluções da questões afetas à seguridade social.

${ }^{289}$ REALE JÚNIOR. Miguel. Despenalização no direito penal econômico: uma terceira via entre o crime e a infração administrativa? Revista Brasileira de Ciências Criminais, São Paulo, v. 7, n. 28, p. 116-129, out./dez. 1999.

${ }^{290}$ MARQUES NETO, Floriano Azevedo. Agências Reguladoras Independentes. Fundamentos e seu Regime Jurídico. Belo Horizonte: Fórum, 2005. p. 121.

${ }^{291}$ Conforme artigo 95 da Constituição da República, os juízes gozam de vitaliciedade, inamovibilidade e irredutibilidade de subsídio. Pelo sistema de mandato transitório proposto não se aplicaria, por consequêencia, a garantia da vitaliciedade.
} 
designação dos componentes do Tribunal Administrativo Penal caberia, exclusivamente, ao chefe do Poder Executivo, dentre pessoas graduadas em área correlata à seguridade social (Direito, Administração, Economia), sendo que os escolhidos deveriam ser referendados pelo Senado Federal.

Outra característica importante, indispensável a fim de preservar o viés técnico dos julgamentos é a independência do Tribunal Administrativo Penal. Essa independência deve se refletir em autonomia orçamentária, nos moldes, por exemplo, do que hoje funciona para o Poder Judiciário ${ }^{292}$. As penalidades monetárias aplicadas pelo Tribunal seriam revertidas em benefício do próprio órgão. Deve ser dotado, ainda, de autonomia administrativa, a fim de que possa internamente organizar seus serviços, criando e extinguindo órgãos internos e definindo, domesticamente, as competências de cada um de seus membros.

Os Tribunais Administrativos Penais corroborariam constatação segundo a qual o Estado brasileiro, no seu processo de despatrimonialização ou de republicização, aponta para lentos, mas constantes, avanços no sentido de dotar o país de uma máquina pública profissional, estável e capacitada $(. . .)^{293}$.

No que concerne às penalidades aplicáveis, pode-se tomar como parâmetro a multa estipulada pela legislação espanhola, que prevê o pagamento de até o sêxtuplo do valor não arrecadado. Estabelecer-se-iam critérios progressivos de aplicação da penalidade, verbi gratia, o valor a ser estipulado na primeira infração equivale ao dobro do valor não arrecadado. Na segunda infração, o valor seria o quádruplo e, a partir da terceira, o sêxtuplo.

Poder-se-iam lançar mão de institutos de penalização da própria pessoa jurídica, quando o ato for praticado em seu claro benefício. Por decisão do Tribunal Administrativo Penal, ficaria a pessoa jurídica impedida de contratar com o poder público $^{294}$, bem como sujeita a multa autônoma daquela aplicada às pessoas físicas que

${ }^{292}$ A Constituição da República garante, no artigo 99, autonomia administrativa e financeira ao Poder Judiciário.

${ }^{293}$ MARQUES NETO, Floriano Azevedo. Agências Reguladoras Independentes. Fundamentos e seu Regime Jurídico. Belo Horizonte: Fórum, 2005. p. 82.

${ }^{294}$ Tal disposição já consta expressamente da Constituição da República de 1988, no § $3^{\circ}$ do artigo 195: A pessoa jurídica em débito com o sistema da seguridade social, como estabelecido em lei, não poderá contratar com o Poder Público nem dele receber benefícios ou incentivos fiscais ou creditícios. 
engendraram a ação contrária aos interesses da arrecadação para o custeio da seguridade social.

E a extinção da punibilidade pelo pagamento? Poderia ser aplicada pelo sugerido Direito Administrativo Penal? Sendo um instituto que proporciona a reconstrução do bem jurídico lesado, não se pode deixar de analisar a questão e buscar harmonizar a extinção da punibilidade com o Direito Administrativo Penal. A proposta de adoção da extinção da punibilidade pelo pagamento é interessante, desde que também seja atribuído ao acusado algum outro ônus financeiro. Por exemplo, a extinção da punibilidade só se efetivaria se o pagamento fosse realizado em dobro, a fim de que a atitude ilícita do sujeito ativo viesse a ser efetivamente sancionada. Por uma questão de proporcionalidade, parece correto punir o agente com a exata medida do prejuízo que ele buscou trazer ao órgão de arrecadação previdenciária.

Assim, fica proposto o seguinte sistema de penalização: o pagamento do valor indevidamente apropriado ou sonegado, não traria qualquer efeito sobre a persecução administrativo-penal. Essa seguiria seu rumo, ficando estabelecida a sanção do dobro do valor indevidamente retido. Na primeira reincidência a sanção seria fixada no quádruplo e, a partir da segunda reincidência, no sêxtuplo do valor devido. Caso o sujeito ativo decida pela extinção da punibilidade, deve pagar o valor devido e acrescentar a esse montante mais uma parcela igual, ou seja, haverá arrecadação em dobro do valor devido e será extinta a punibilidade.

Crê-se, assim, com a criação de Tribunais Administrativos Penais, que teriam jurisdição ${ }^{295}$ sobre as infrações contra a arrecadação para a seguridade social, o bem jurídico seria mais eficazmente tutelado. O órgão de julgamento especializado traria mais precisão técnica e agilidade à resposta e a justiça penal não seria exposta a situações de descrédito, como ocorre hoje, por exemplo, em razão da extinção da punibilidade pelo pagamento.

\footnotetext{
${ }^{295}$ No tocante aos poderes quase judiciais, é fato que não há a possibilidade de estes poderes importarem em interdição ao controle judicial dos atos do regulador. Isso sim seria inconstitucional (Cf. art. $\left.5^{\circ}, X X X V, C F\right)$. Porém não nos parece que seja írrito à Constituição que órgãos não judiciais exerçam a composição de interesses e que tais decisões tenham caráter de exigibilidade. Isso já ocorre com os Tribunais Arbitrais e com as comissões de conciliação, sem questionamentos quanto à sua constitucionalidade (MARQUES NETO, Floriano Azevedo. Agências Reguladoras Independentes. Fundamentos e seu Regime Jurídico. Belo Horizonte: Fórum, 2005. p. 109).
} 


\section{CONCLUSÕES}

A seguridade social compreende um complexo sistema de arrecadação, administração e distribuição de riquezas, que procura prover as necessidades dos indivíduos em momentos de dificuldade. Desde a Antiguidade se pode identificar o embrião dos atuais sistemas de proteção social, o que demonstra ser inerente à natureza humana e à vida em sociedade a repartição das vicissitudes individuais. A instituição do Estado, como ente provedor, tem o condão de estatizar a solidariedade, gerando nos cidadãos o abandono de ações individuais. Assim, a solidariedade passa a ser responsabilidade estatal, e não mais individual. Surge, como imperativo, a criação dos sistemas de custeio, entre os quais se destacam o Bismarckiano e o Beverdgeano.

No Brasil, todos os textos constitucionais, desde a Carta de 1824, que se referia aos socorros públicos, tratam da seguridade social com maior ou menor ênfase. A Carta republicana de 1891 é a primeira constituição a utilizar a expressão aposentadoria. Ganham destaque também os textos infraconstitucionais, notadamente a Lei Eloy Chaves, de 1923. Em 1930, sob os auspícios de Vargas, é criado o Ministério do Trabalho. Na Constituição de 1934 é utilizada, pela primeira vez, a palavra previdência sendo instituída a tríplice forma de custeio. Na Carta de 1937 foram previstos os seguros sociais; a expressão previdência social tem registro na Constituição de 1946. A clientela do sistema de previdência cresce bastante sob a ordem da Constituição de 1967 (alterada pela Emenda Constitucional $\left.n^{\circ} 1 / 69\right)$. Se comparadas as previsões constitucionais acerca da matéria é possível enxergar uma crescente importância dos institutos de seguridade social, o que permite concluir pela evolução do sistema, em que pesem algumas pontuais regressões, como a do texto de 1937.

$\mathrm{Na}$ atual ordem constitucional, a seguridade social merece destaque, sendo gênero do qual são espécies a assistência à saúde, a previdência social e a assistência social. A seguridade social, hoje, compreende um conjunto integrado de ações, de responsabilidade do poder público e de toda a sociedade. Tem a seguridade social suas bases fincadas no texto constitucional, o que permite sejam as condutas que a ela ofendem perseguidas pelo Direito Penal. 
O custeio da seguridade social se dá através de espécie do gênero tributo, as contribuições sociais.

Não se prescinde do bem jurídico no atual estágio de desenvolvimento do Direito Penal brasileiro. É ele que permite preencher a norma de conteúdo, a fim de delimitar com precisão as condutas criminalizadas. O bem jurídico é conceito que evoluiu juntamente com o Direito Penal, desempenhando importante papel na contenção do direito de punir. Serve o bem jurídico, também, a indicar se é mais viável e eficiente repreender as condutas que lhe são ofensivas pelo Direito Penal ou pelo Direito Administrativo.

Há razoável divergência acerca do bem jurídico tutelado pelos delitos previdenciários. Pode-se afirmar, entretanto, que o bem jurídico tutelado por tais crimes é a arrecadação para a seguridade social.

Desde 1937 a legislação brasileira pune como crime a apropriação indébita previdenciária. Diversos textos normativos, ao longo dos anos, exerceram essa função, sendo que já houve época em que referida conduta era punida pelo mesmo dispositivo que incrimina a sonegação fiscal. Hoje, pela Lei n ${ }^{\circ}$ 9.983/00, inseriu-se no Código Penal o artigo 168-A, que descreve o crime de forma autônoma.

A origem do tipo de apropriação indébita previdenciária remonta à clássica apropriação indébita, que desde o Código Criminal do Império, de 1830, era criminalizada como uma espécie de furto. É apenas com o Código Penal de 1940 que a apropriação indébita ganha autonomia, passando a figurar como crime patrimonial.

Ao lado da apropriação indébita previdenciária, o Código Penal também acolhe, hoje, o crime de sonegação de contribuição previdenciária, no artigo 337-A. A apropriação indébita previdenciária e a sonegação de contribuição previdenciária são crimes que têm como uma de suas principais características serem tipos penais em branco, pois o intérprete depende da intelecção de muitas normas integrativas para extrair do texto do Código Penal seu preciso conteúdo. Se comparadas as duas condutas delituosas, a sonegação de contribuição previdenciária, por demandar uma prévia ação de falso, encerra mais desvalor do que a apropriação indébita previdenciária.

$\mathrm{Na}$ legislação de países com os quais se cotejou a legislação brasileira Portugal, Itália e Espanha - também foi possível encontrar a criminalização de condutas 
ofensivas à seguridade social. Como regra, esses países não punem toda e qualquer conduta lesiva, pois se estabelece uma linha de corte, em que as lesões de valores inferiores ficam a salvo da criminalização.

A punibilidade, hodiernamente, não mais é considerada elemento do crime; sua ausência, entretanto, impede a aplicação da sanção penal. Fenômeno que ocorre hoje com relação aos delitos previdenciários é uma obtusa descriminalização, por via da decretação da extinção da punibilidade pelo pagamento. Assim, adota-se no Brasil uma fórmula que extrai a sanção das condutas ofensivas à seguridade social por um método cientificamente contestável, pois um ato posterior do sujeito ativo tem o condão de extinguir a punibilidade e afastar a pena. Busca-se, assim, a eficiência da arrecadação, através de uma lógica que não leva em consideração elementos caros ao Direito, como ética, justiça e igualdade. A tutela penal começa a se mostrar débil como sistema de proteção das condutas ofensivas à seguridade social, pois admite exceção que depõe contra vários dos fundamentos do Direito.

O Direito Penal, como todo ramo do Direito, lança mão de sanções para conformar o comportamento humano e por ser dotado da mais aguda das sanções - a privação da liberdade - deve ter seu campo de atuação rigidamente controlado. Nem todo ilícito pode ser tutelado pelo Direito Penal, já que o bem jurídico que ele fere - a liberdade - é valor constitucionalmente protegido. A seguridade social, como bem jurídico de destacada relevância social, tem estatura penal, o que autoriza sejam condutas ofensivas à sua arrecadação punidas criminalmente.

Na concepção de Miguel Reale Júnior, a proteção pela via Penal ou via extraPenal não tem, em essência, diferencial. O critério é de Política Legislativa, e se deve optar pela via que seja mais eficiente. Para os crimes econômicos Miguel Reale Júnior advoga a instituição de um Tribunal Administrativo Penal, em cuja jurisdição estariam garantidos alguns corolários do Direito Penal, como o princípio da legalidade, mas se poderia adotar outras estruturas para evitar, por exemplo, a necessidade da prova do dolo. A idéia defendida admite a flexibilização de algumas características do Direito Penal clássico, a fim de que a tutela seja mais efetiva. Em contrapartida estaria afastada a pena privativa de liberdade. 
Os delitos previdenciários não estão incluídos entre os objetos de estudo do Direito Penal Econômico. Mesmo assim, por terem alguns pontos de contato com esse, deveriam ser adotadas semelhantes estruturas de proteção. Sugere-se a adoção do Direito Administrativo Penal para os delitos contra a arrecadação da seguridade social. Acredita-se que assim o sistema de coerção passe a atuar de modo mais efetivo, pois haveria grande especialização dos órgãos do julgamento, que solucionariam as controvérsias de maneira mais ágil e mais concertada à proteção do bem jurídico.

A doutrina administrativista, representada por Floriano de Azevedo Marques Neto, fornece alguns elementos que podem ser utilizados como paradigma para que se construa um adequado órgão de aplicação do Direito Administrativo Penal.

Como outro benefício, a justiça penal ficaria a salvo do descrédito que atualmente se lhe imputa pela falta de efetividade, podendo reservar suas forças para a proteção de outros bens jurídicos, em que se apresente mais eficiente a sua tutela. 


\section{REFERÊNCIAS}

ALONSO, Leonardo. Novo Refis altera regras para a extinção da punibilidade nos chamados crimes tributários. Disponível em www.conjur.com.br. Acesso em 20.12.2003.

ASÚA, Luis Jiménez de. Tratado de Derecho Penal. t. 1. 2. ed. Buenos Aires: Losada, 1956.

AZEVEDO, David Teixeira. Concurso aparente de normas penais: uma aproximação. Experiências do Direito. Campinas: Millennium, 2004.

BALERA, Wagner. Crime Tributário de Apropriação Indébita. Repertório de Jurisprudência IOB, São Paulo, n. 4, p. 83-6, fev. 1998.

BALTAZAR JUNIOR, José Paulo. O crime de omissão no recolhimento de contribuições sociais arrecadadas. Porto Alegre: Livraria do Advogado, 2000.

BARETTA. Gliciane Allen Baretta. Os Crimes Fiscais e Previdenciários. A extinção da Punibilidade. Belo Horizonte: Mandamentos, 2004.

BARROS, Roque Spencer Maciel de. A face humana do liberalismo. [on line]. Jornal da USP. Entrevista. a Roberto C. G. Castro. Disponível em <http://www.usp.br/ jorusp/arquivo/1997/jusp400/manchet/rep_res/rep_int/univers2.html $>, \quad$ acesso em 20.abr.2006.

BATTAGLINI, Giulio. Direito Penal: parte geral. Trad. Paulo José da Costa Jr. e Arminda Bergamini Miotto. São Paulo: Saraiva, 1973.

BERBEL, Fábio Lopes Vilela. Teoria Geral da Previdência Social. São Paulo: Quartier Latin, 2005.

BITENCOURT, Cesar Roberto. Tratado de Direito Penal - Parte Especial. v. 3. São Paulo: Saraiva, 2003.

BRUNO, Aníbal. Direito Penal, parte geral. t. 1-2. 3. ed. Rio de Janeiro, 1967

Caldas Aulete. Dicionário Contemporâneo da Língua Portuguesa. 5ed. Rio de Janeiro: Delta, 1964.

CASTILHO, Ela Wiecko Volkner de. Crimes contra a previdência social. Revista da Procuradoria-Geral da República. n. 8, p. 127-37, jan./jun. 1996.

COÊLHO, Sacha Calmon Navarro. Comentários à Constituição de 1988: sistema tributário. 3. ed. Rio de Janeiro: Forense, 1991. 
COELHO, Yuri Carneiro. Bem jurídico-penal. Belo Horizonte: Mandamentos, 2003.

CORREIA, Marcos Orione Gonçalves; CORREIA, Érika Paula Barcha. Curso de Direito da Seguridade Social. 2ed. São Paulo: Saraiva, 2002.

COSTA JR., Paulo José. Direito Penal. Curso Completo. 5ed. São Paulo: Saraiva, 1999.

COSTA, Helena Regina Lobo da. Proteção ambiental, direito penal e direito administrativo. Tese de Doutorado. Faculdade de Direito da Universidade de São Paulo, São Paulo, 2007.

DELMANTO, Celso et al. Código Penal Comentado. 6. ed. Rio de Janeiro: Renovar, 2002.

DI PIETRO, Maria Sylvia Zanella. Direito Administrativo. 10. ed. São Paulo: Atlas, 1999.

DIAS, Jefferson Aparecido. Crime de Apropriação Indébita Previdenciária. CP, art. 168A, $\S 1^{o}$, inc. I. 2. ed. Curitiba: Juruá, 2007.

DIAS, Jorge de Figueiredo; ANDRADE, Manuel da Costa. Problemática Geral das Infracções contra a Economia Nacional. Temas de Direito Penal Econômico. org. Roberto Podval. São Paulo: Revista dos Tribunais, 2000.

DOTTI, René Ariel. Curso de Direito Penal. Parte Geral. Rio de Janeiro: Forense, 2003.

DOTTI, René Ariel. Teoria Geral da Punibilidade. Revista CEJ. Brasília. v. 3. n. 7. p. 2431. abr. 1999.

ESTELLITA, Heloisa. Crimes Tributários nos Tribunais Superiores. Revista Brasileira de Ciências Criminais, São Paulo, v. 14, n. 58, p. 85-104, jan./fev. 2006.

ESTELLITA, Heloisa. O parcelamento previsto na MP 303/06 e a punibilidade nos crimes tributários. Boletim IBCCRIM, São Paulo, ano 14, n.165, p. 14, ago. 2006.

FARIA JÚNIOR, César de. Crime Previdenciário. Revista Brasileira de Ciências Criminais. São Paulo, v. 3, n. 11, p. 113-7, jul./set. 1995.

FERRARI, Eduardo Reale. Legislação Penal Antitruste: Direito Penal Econômico e sua Acepção Constitucional. Experiências do Direito. Campinas: Millenium, 2004. p. 253-315.

FIGUEIREDO DIAS, Jorge de e COSTA ANDRADE, Manuel da. Problemática geral das infrações contra a economia nacional. Temas de Direito Penal Econômico. org. Roberto Podval. São Paulo: RT, 2001.

FRAGOSO, Heleno Cláudio. Lições de Direito Penal. A nova Parte Geral. Rio de Janeiro: Forense, 1986. p. 1. 
GARCIA, Basileu. Instituições de Direito Penal. v. 1. t. 1. São Paulo: Max Limonad, 1973.

GOMES, Luis Flávio. Da apropriação indébita previdenciária: art. 168-A do Código Penal, com redação dada pela Lei ${ }^{\circ} 9.983$ de 14.07.00. Repertório de Jurisprudência IOB, São Paulo, n. 17, p. 366-9, set. 2000.

GONÇALVES, Carlos Roberto. Direito das Coisas. v. 3. 5. ed. São Paulo: Saraiva, 2002.

HABERMAS, Jürgen. Agir comunicativo e razão destrancentralizada. Rio de Janeiro: Tempo Brasileiro, 2002.

HERKENHOFF, Henrique Geaquintino. Novos crimes previdenciários. Rio de Janeiro: Forense, 2001. p. 10.

HUNGRIA, Nélson. Comentários ao Código Penal. 5. ed. Rio de Janeiro: Forense, 1979.

HUNGRIA, Nélson; FRAGOSO, Heleno Cláudio. Comentários ao Código Penal. v. VII. 4. ed. Rio de Janeiro: Forense, 1980.

IBAIXE JUNIOR, João. Crimes Previdenciários: garantismo penal e responsabilidade da pessoa jurídica. Revista de Previdência Social. São Paulo, v. 27, n. 272, p. 549-51, jul. 2003.

JAKOBS, Günther. ¿Qué protege el Derecho Penal: bienes jurídicos o la vigência de la norma? Mendoza: Cuyo.

JAKOBS, Günther. Ciência do Direito. Coleção Estudos de Direito Penal. Barueri: Manole, 2003.

JORGE, Társis Nametala Sarlo. Teoria Geral do Direito Previdenciário. Rio de Janeiro: Lumen Juris, 2005.

LISZT, Franz von. Tratado de Direito Penal allemão. trad. José Hygino Duarte Pereira. Brasília: Senado Federal, 2006.

LOPES, Mauricio Antonio Ribeiro. O princípio da proporcionalidade no direito penal econômico. Temas de Direito Penal Econômico. org. Roberto Podval. São Paulo: Revista dos Tribunais, 2000.

MACHADO, Hugo de Brito. Apropriação indébita e dívida de tributo. IOB - Repertório de Jurisprudência civil, processual, penal e comercial. São Paulo, n. 12, p. 229-30, jun. 1994.

MACIEL FILHO, Euro Bento. Crimes Previdenciários. São Paulo: Juarez de Oliveira, 2004. 
MARKY, Thomas. Curso Elementar de Direito Romano. 8. ed. São Paulo: Saraiva, 1995.

MARQUES, José Frederico. Curso de Direito Penal. v. 1. São Paulo: Saraiva, 1954.

MARQUES NETO, Floriano Azevedo. Agências Reguladoras Independentes. Fundamentos e seu Regime Jurídico. Belo Horizonte: Fórum, 2005.

MARTINS, Sergio Pinto. Direito da Seguridade Social. 9. ed. São Paulo: Atlas, 1998.

MARTINS, Sergio Pinto. Fundamentos de Direito da Seguridade Social. 7. ed. São Paulo: Atlas, 2006.

MESTIERI, João. Manual de Direito Penal. Parte Geral. v. 1. Rio de Janeiro: Forense, 1999.

MIR PUIG, Santiago. Direito Penal. Fundamentos e Teoria do Delito. Trad. Cláudia Viana Garcia e José Carlos Nobre Porciúncula Neto. São Paulo: RT, 2007.

MIRABETE, Julio Fabbrini. Manual de Direito Penal. v1. 21ed. São Paulo: Atlas, 2004.

MONTEIRO, Antonio Lopes. Crimes contra a Previdência Social. 2. ed. São Paulo: Saraiva, 2003.

MORAES, Alexandre de. Direito Constitucional. 16. ed. São Paulo: Atlas, 2004. p. 317.

PASCHOAL, Janaina Conceição. Constituição, criminalização e direito penal mínimo. São Paulo: RT, 2003.

PASCHOAL, Janaina Conceição. Direito Penal. Parte Geral. Barueri, SP: Manole, 2003.

PELARIN, Evandro. Bem jurídico-penal. Um debate sobre a descriminalização. São Paulo: IBCCRIM, 2002.

PIERANGELI, José Henrique. Códigos Penais do Brasil: Evolução histórica. São Paulo: RT, 2005.

PIERDONÁ, Zélia Luiza. Contribuições para a Seguridade Social. LTr: São Paulo, 2003.

PIMENTEL, Manoel Pedro. Direito Penal Econômico. São Paulo: RT, 1973.

PODVAL, Roberto; MANDEL, Paula Kahan. Crimes de Apropriação Indébita e de Sonegação de Contribuição Previdenciária - Comentários Críticos à Lei n. 9.983, de 17.2.2000. Revista Dialética de Direito Tributário. São Paulo, n. 65, p. 106-22, fev. 2001.

PRADO, Luiz Régis. Curso de Direito Penal Brasileiro. v. 4. 4. ed. São Paulo: RT, 2006. 
REALE JÚNIOR, Miguel. Ação Fiscal e Extinção da Punibilidade no Crime Tributário. Disponível em <www.realeadvogados.com.br>. Acesso em 30.1.2007.

REALE JÚNIOR, Miguel. Instituições de Direito Penal. v. I e II. 2. ed. Rio de Janeiro: Forense, 2004.

REALE JÚNIOR, Miguel. Não há apropriação indébita por equiparação. Revista dos Tribunais. São Paulo, v. 87, n. 752, p. 467-77, jun. 1998.

REALE JÚNIOR, Miguel. Teoria do Delito. 2. ed. São Paulo: RT, 2000.

REALE JÚNIOR. Miguel. Despenalização no direito penal econômico: uma terceira via entre o crime e a infração administrativa? Revista Brasileira de Ciências Criminais, São Paulo, v. 7, n. 28, p. 116-129, out./dez. 1999.

RÍOS, Rodrigo Sánches. Das Causas de Extinção da Punibilidade nos Delitos Econômicos. São Paulo: RT, 2003.

ROCHA, Daniel Machado da. O Direito Fundamental à Previdência Social. Porto Alegre: Livraria do Advogado, 2004.

ROSA, Fabio Bittencourt da. Legitimação do ato de criminalizar. Porto Alegre: Livraria do Advogado, 2001.

ROSA, Márcio Fernando Elias. Direito Administrativo. 9. ed. São Paulo: Saraiva, 2007.

SALOMÃO, Heloisa Estellita. Crimes previdenciários: arts. 168-A e 337-A do CP: aspectos gerais. Revista Brasileira de Ciências Criminais. São Paulo, v. 9, n. 36, p. 309-50, out./dez. 2001.

SALOMÃO, Heloisa Estellita. Extinção da punibilidade pelo pagamento nos crimes tributários e previdenciários após o advento da lei 9.983/00. Revista Síntese de Direito Penal e Processual Penal. Porto Alegre. v. 2, n. 8, p. 63-5, jun./jul. 2001.

SALOMÃO, Heloisa Estellita. Novos Crimes Previdenciários - Lei no 9.983/00, de 14 de julho de 2000: Primeiras Impressões. Revista Dialética do Direito Tributário. São Paulo, n. 64, p. 70-90, jan./2001.

SALOMÃO, Heloisa Estellita. O crime de não-recolhimento de contribuições previdenciárias. Revista Dialética de Direito Tributário. São Paulo, n. 6, p. 36-47, mar. 2006.

SÁNCHES, Jesus Maria Silva. Eficiência e Direito Penal. trad. Mauricio Ribeiro Lopes. Barueri: Manole, 2004. 
SANTOS, Leandro Luis Camargo dos. Curso de Direito da Seguridade Social. São Paulo: LTr, 2004.

SILVA, José Afonso da. Curso de Direito Constitucional Positivo. 10. ed. São Paulo: Malheiros, 1995.

STOCO, Rui in FRANCO, Alberto Silva et. al. Leis Penais Especiais e sua Interpretação Jurisprudencial. 6. ed. São Paulo: RT, 1997.

TAVARES, Marcelo Leonardo. Direito Previdenciário. 5. ed. Rio de Janeiro: Lumen Juris, 2003.

VIANNA, Maria Lucia T. Werneck. Articulação de Interesses, Estratégias de Bem-estar e Políticas Públicas: A Americanização (perversa) da Seguridade Social no Brasil. Tese de Doutorado. Instituto Universitário de Pesquisas do Rio de Janeiro, Rio de Janeiro, 1995.

WEINTRAUB, Arthur Bragança de Vasconcellos e BARRA, Juliano Sarmento. Direito sanitário previdenciário e trabalhista. São Paulo: Quartier Latin, 2006.

WELZEL, Hans. O novo sistema jurídico-penal. trad. Luiz Regis Prado. São Paulo: RT, 2001.

ZILBERSTAJN, Decio; STAJN, Rachel. Análise Econômica do Direito e das Organizações. Direito \& Economia. Rio de Janeiro: Elsevier, 2005. 


\section{RESUMO}

Com o constante aumento da longevidade, os homens, cada vez mais, preocupam-se com a manutenção da qualidade de vida após se afastarem do mercado de trabalho. Também ganham destaque as apreensões com eventuais doenças e imprevistos que impeçam o pleno desenvolvimento da atividade laborativa, com a conseqüente diminuição dos rendimentos. O Direito, como sistema de controle social, cumpre relevante papel nesse contexto. Os institutos de seguridade social, ainda que de modo parcial, respondem ao anseio social de tranqüilidade nos momentos difíceis da vida. Ao Direito cabe organizá-los e zelar por sua higidez.

O presente trabalho discorreu acerca das origens dos institutos de seguridade social, bem como sobre os principais sistemas de custeio. Com relação ao Brasil, foram abordadas questões relativas à origem da seguridade, o arcabouço constitucional e a natureza jurídica da contribuição previdenciária.

No momento seguinte, passou-se à análise específica do bem jurídico tutelado pelos chamados crimes previdenciários, não sem antes tecer considerações indispensáveis à correta delimitação e utilidade da adoção do bem jurídico como limitador do poder punitivo. Delimitado o âmbito de atuação da norma jurídica penal, empreendeu-se o estudo dogmático das figuras de criminalização hoje presentes em nossa legislação, quais sejam, a apropriação indébita previdenciária e a sonegação de contribuição previdenciária.

A titulo comparativo foi descrita, em linhas gerais e em caráter superficial, a legislação sobre o tema adotada em Portugal, Itália e Espanha. Estudou-se a obtusa descriminalização das condutas contra a seguridade social, haja vista a adoção de inúmeros instrumentos de extinção da punibilidade, na linha da Análise Econômica do Direito (Law and Economics).

Discutiu-se acerca da necessidade e viabilidade da proteção da seguridade social por meio do Direito Penal, tendo em conta, como principal alternativa, a adoção de medidas administrativas de coerção.

Por fim, foram expostas as conclusões do trabalho. 


\section{RIASSUNTO}

In ragione dell'aumento costante della longevità, la qualità della vita dopo aver lasciato il mercato di lavoro preoccupa sempre di più le persone. Guadagnano ulteriore rilievo anche le apprensioni riguardo ad eventuali malattie o imprevisti che vengano ad impedire lo sviluppo dell'attività lavorativa con la conseguente riduzione del reddito. Il Diritto, come sistema di controllo sociale, esercita un ruolo rilevante in tale contesto. Gli istituti della previdenza sociale, anche se solo parzialmente, rispondono ai desideri sociali di tranquillità nei momenti difficili della vita. Tocca al Diritto organizzarli e vegliare sulla loro salute.

Il presente lavoro discorre sulle origini degli istituti di previdenza sociale nonché sui suoi principali sistemi di finanziamento. Riguardo al Brasile, sono state prese in considerazione le questioni relative alle origini della previdenza, la struttura costituzionale e la natura giuridica del contributo previdenziale.

Si è passati, in seguito, all'analisi specifica del bene giuridico tutelato dai cosiddetti illeciti previdenziali non senza aver fatto prima le necessarie considerazioni, indispensabili alla corretta delimitazione e all'utilità dell' adozione del bene giuridico come limitatore del potere punitivo. Una volta delimitato l'ambito di attuazione della norma giuridica penale si è intrapreso lo studio dogmatico delle figure di inquadramento penale presenti oggi nella nostra legislazione quali l'appropriazione indebita e l'evasione del contributo previdenziale.

A titolo di paragone sono state descritte a grandi linee e in modo non approfondito le legislazioni adottate sullo stesso argomento nel Portogallo, in Italia e in Spagna. Si è studiata l'ottusa depenalizzazione delle condotte contro la previdenza sociale quale l'adozione di svariati strumenti di estinzione della punibilità, in linea con l'Analisi Economica del Diritto (Law and Economics).

Si è discussa la necessità e la fattibilità della protezione della previdenza pociale per mezzo del Diritto Penale, considerando, come principale alternativa, l'adozione di misure amministrative coercitive.

Per concludere sono state esposte le conclusioni finali del lavoro. 


\section{RESUMEN}

Con el constante aumento de longevidad, los hombres, cada vez más, se preocupan en mantener la calidad de vida, después de dejar, el mercado de trabajo. También ganan influencia, las preocupaciones con eventuales enfermedades imprevistas, que impidan el completo desarrollo de la actividad laboral, con la consecuente disminución de sus ingresos. El Derecho, como sistema de control social, cumple significativo rol en este contexto. Los institutos de seguridad social, aún cuando de forma parcial, responden al deseo social de tranquilidad en los momentos difíciles de la vida. Al Derecho cabe organizarlos y cuidar de su buen funcionamiento.

El presente trabajo disertó acerca de los orígenes de los institutos de seguridad social, así como sobre los principales sistemas de costeo. Con relación a Brasil, fueron abordadas cuestiones relativas al origen de la seguridad, el esqueleto de este sistema constitucional y la naturaleza jurídica del aporte, para el sistema provisional.

En el momento siguiente, prosiguió con un análisis especifico de lo bien jurídico de los llamados crímenes de previsión, no sin antes elucubrar consideraciones indispensables para la correcta delimitación y utilidad de la adopción del bien jurídico, como limitador del poder punitivo. Delimitado el ámbito de actuación de la norma jurídica penal, se inició el estudio dogmático de las figuras de criminalidad, hoy presentes en nuestra legislación, como son, la apropiación indebida de recursos provisionales y la evasión de pago provisional.

Como titulo comparativo fueron descritas, en pocas líneas y de forma superficial, la legislación sobre el tema adoptado en Portugal, Italia y España. Se estudió la tardía comprensión de las conductas contra la seguridad social, teniendo en cuenta la adopción de innúmeros instrumentos de extinción de las puniciones, en la línea del Análisis Económico del Derecho (Law and Economics).

Fue discutido acerca de la necesidad y viabilidad de la protección de la seguridad social, por medio del Derecho Penal, tomando en cuenta, como principal alternativa, la adopción de medidas administrativas de coerción.

Por fin, fueron expuestas las conclusiones del trabajo. 


\section{RÉSUMÉ}

Avec la constante augmentation de la longévité, l'homme se soucie de plus en plus du maintien de la qualité de la vie après la retraite. Les craintes liées à d'éventuelles maladies et à des imprévus nuisant au plein développement de l'activité au travail, et la diminution des revenus qui en découle, figurent aussi au premier rang des préoccupations. Le Droit, en tant que système de contrôle social, joue un rôle majeur dans ce cadre. Les instituts de sécurité sociale répondent, ne serait-ce que partiellement, au désir social de sérénité dans les moments difficiles de la vie. C'est au Droit qu'il revient d'y veiller et d'y mettre de l'ordre.

La présente étude remonte aux origines des instituts de sécurité sociale, ainsi que sur les principaux systèmes de financement. Quant au Brésil plus précisément, au-delà des origines, on s'intéresse également au cadre constitutionnel et à la forme juridique de la cotisation.

On passe ensuite à l'analyse spécifique du bien juridique visé par ce qu'on appelle les crimes contre la sécurité sociale, non sans faire quelques considérations préalables indispensables à une correcte délimitation et sur l'utilité de l'adoption du bien juridique comme limite au pouvoir punitif. Une fois défini le cadre d'application de la norme juridique pénale, on entreprend l'étude dogmatique des cas de figures de criminalisation aujourd'hui présents dans notre législation, soit l'appropriation indue et la fraude à la cotisation de sécurité sociale.

A titre comparatif, on décrit, à grands traits, la législation sur le même thème, au Portugal, en Italie et en Espagne. On étudie, l'obtuse décriminalisation des atteintes à la sécurité sociale, au vu de l'adoption d'innombrables instruments d'extinction de la punibilité, à la lumière de l'Analyse Économique du Droit (Law and Economics).

On y discute également la nécessité et la viabilité de la protection de la sécurité sociale par le biais du Droit Pénal, en considérant, comme principale alternative, l'adoption de mesures administratives contraignantes.

On en vient finalement aux conclusions de l'étude. 